\title{
Directing the Crystallization of Dehydro[24]annulenes into Supramolecular Nanotubular Scaffolds
}

Mitsuharu Suzuki, Juliet F. Khosrowabadi Kotyk, Saeed I. Khan, and Yves Rubin*

Department of Chemistry and Biochemistry, University of California, Los Angeles, California 90095-1569, United States

\section{Contents}

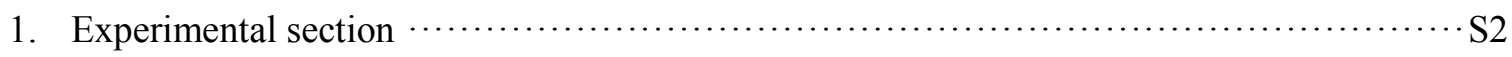

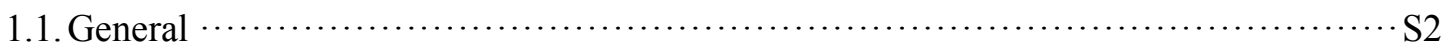

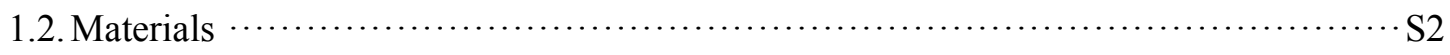

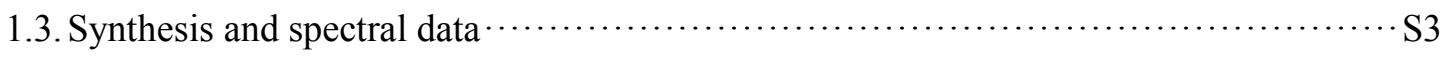

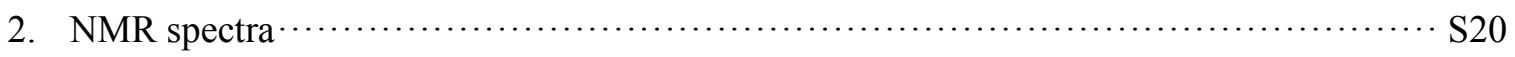

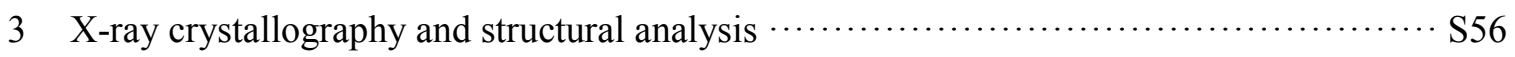

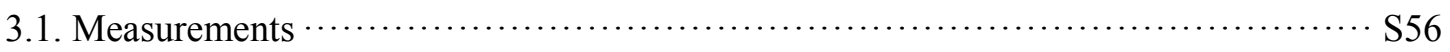

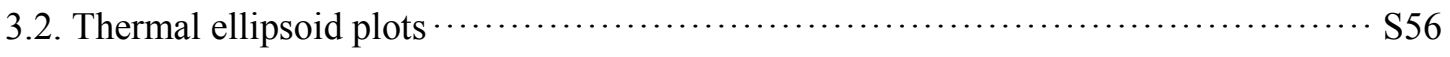

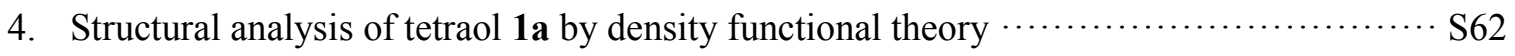

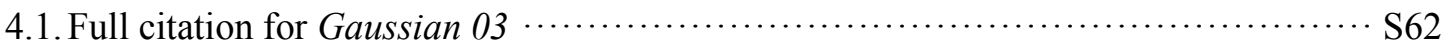

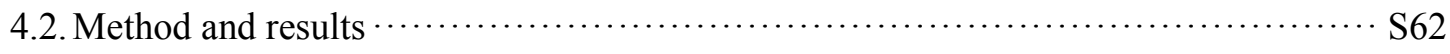

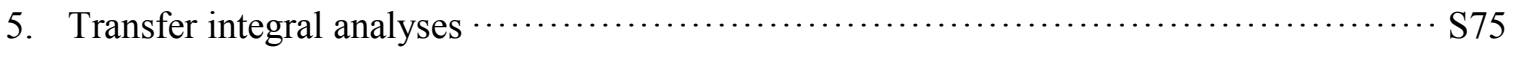

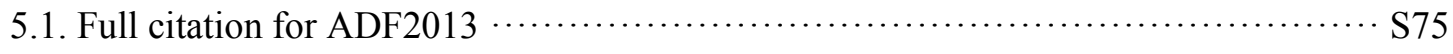

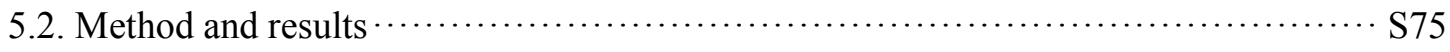

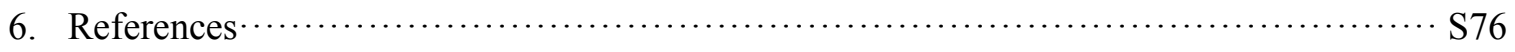




\section{Experimental section}

\subsection{General}

All reactions were carried out under argon unless otherwise noted. ${ }^{1} \mathrm{H}$ and ${ }^{13} \mathrm{C}\left\{{ }^{1} \mathrm{H}\right\}$ NMR spectra were acquired on a Bruker ARX-500 (500 MHz) or DRX-500 (500 MHz) spectrometer at 297-300 K, and chemical shifts were calculated using the solvent resonances as internal standards $\left({ }^{1} \mathrm{H}: 7.26 \mathrm{ppm}\right.$ for $\mathrm{CHCl}_{3}, 2.05 \mathrm{ppm}$ for acetone, $2.50 \mathrm{ppm}$ for DMSO, and $1.73 \mathrm{ppm}$ for THF; ${ }^{13} \mathrm{C}\left\{{ }^{1} \mathrm{H}\right\}: 77.00 \mathrm{ppm}$ for $\mathrm{CDCl}_{3}, 29.92 \mathrm{ppm}$ for acetone- $d_{6}, 39.51 \mathrm{ppm}$ for DMSO- $d_{6}$, and $25.37 \mathrm{ppm}$ for THF- $\left.d_{8}\right)$. Infrared spectra were recorded on a Jasco FT/IR-420 spectrometer, and wavenumbers are reported in $\mathrm{cm}^{-1}$ with peak descriptions: s (strong), m (medium), w (weak), br (broad), sh (shoulder). UV-Vis absorption spectra were measured on a Shimadzu UV-3101PC spectrometer and absorption peak wavelengths were reported in $\mathrm{nm}$ with molar absorptivities in $\mathrm{M}^{-1} \cdot \mathrm{cm}^{-1}$. Mass spectra were acquired on an Applied Biosystems Voyager-DE-STR MALDI-TOF instrument. Column chromatography was performed on silica gel purchased from Sorbent Technologies (standard grade, $60 \AA$, 40-63 $\mu \mathrm{m}$ ). Analytical thin layer chromatography (TLC) was performed on Whatman $250 \mu \mathrm{m}$-thick silica gel 60 plates with a fluorescent indicator. Visualization of TLC spots was accomplished with UV light at $254 \mathrm{~nm}$.

\subsection{Materials}

$\mathrm{CH}_{2} \mathrm{Cl}_{2}$ and THF were distilled under argon immediately before use over drying agents $\left(\mathrm{CaH}_{2}\right.$ for $\mathrm{CH}_{2} \mathrm{Cl}_{2}$, sodium and benzophenone for THF). DMF was distilled under vacuum over $\mathrm{MgSO}_{4}$ and stored on $4 \AA$ molecular sieves. Pyridine and $i$ - $\mathrm{Pr}_{2} \mathrm{NEt}$ were distilled over $\mathrm{CaH}_{2}$ and stored under argon. TMEDA was stored on $4 \AA$ molecular sieves for at least 3 days before use. Oxalamide derivatives $\mathbf{2 a}$ and $\mathbf{2 b}$ were

prepared according to literature. ${ }^{\mathrm{S} 1}$ Other solvents and reagents were obtained from commercial sources and used without further purification. 


\subsection{Synthetic and spectral data}

Tetraol 1a was synthesized according to the previous report. ${ }^{\mathrm{S} 2}$ The benzoate derivatives $\mathbf{1 b}-\mathbf{1 f}$ were synthesized by carbodiimide-mediated esterification of tetraol 1a (Scheme S1). In the cases of hydroxybenzoates $\mathbf{1 b}-\mathbf{1 d}$, the final products were obtained after desilylation of the corresponding precursors. Similarly, phenylcarbamate 1i was obtained by functionalization of 1a (Scheme S1). Other carbamate derivatives $\mathbf{1 g}, \mathbf{1} \mathbf{h}$, and $\mathbf{1 j}$ were prepared by macrocyclization of the corresponding dicarbamates $\mathbf{4 a - 4 c}$, which were formed by either the Lewis-acid- or base-mediated reaction between diol 3 and the corresponding isocyanates (Scheme S2).

Scheme S1. Synthesis of benzoate derivatives $\mathbf{1 b}-\mathbf{1 f}$ and phenylcarbamate $\mathbf{1 i}$.
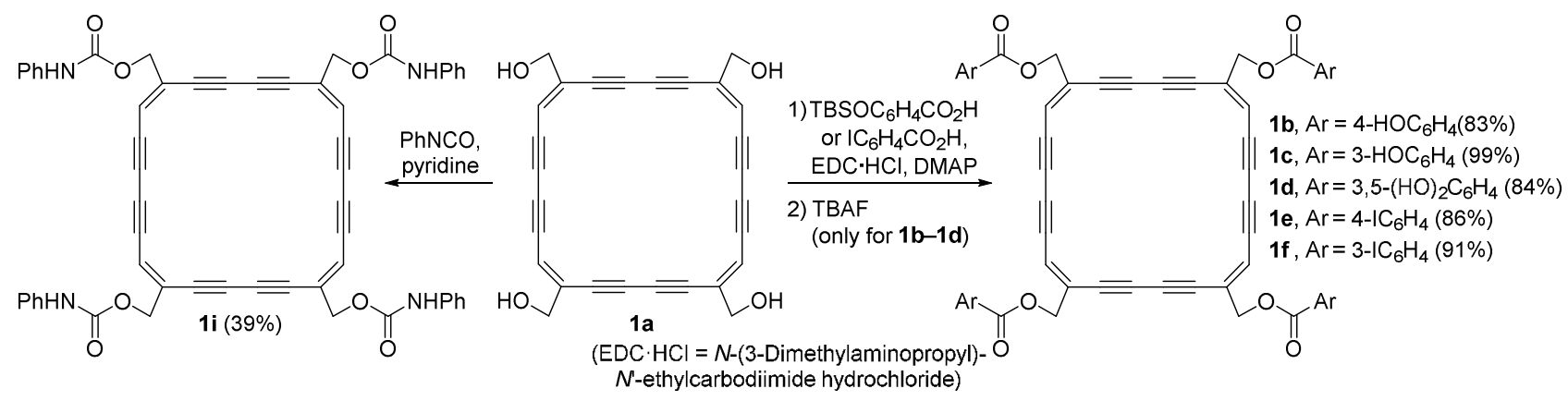

Scheme S2. Synthesis of carbamate derivatives $\mathbf{1 g}, \mathbf{1 h}$, and $\mathbf{1 j}$.

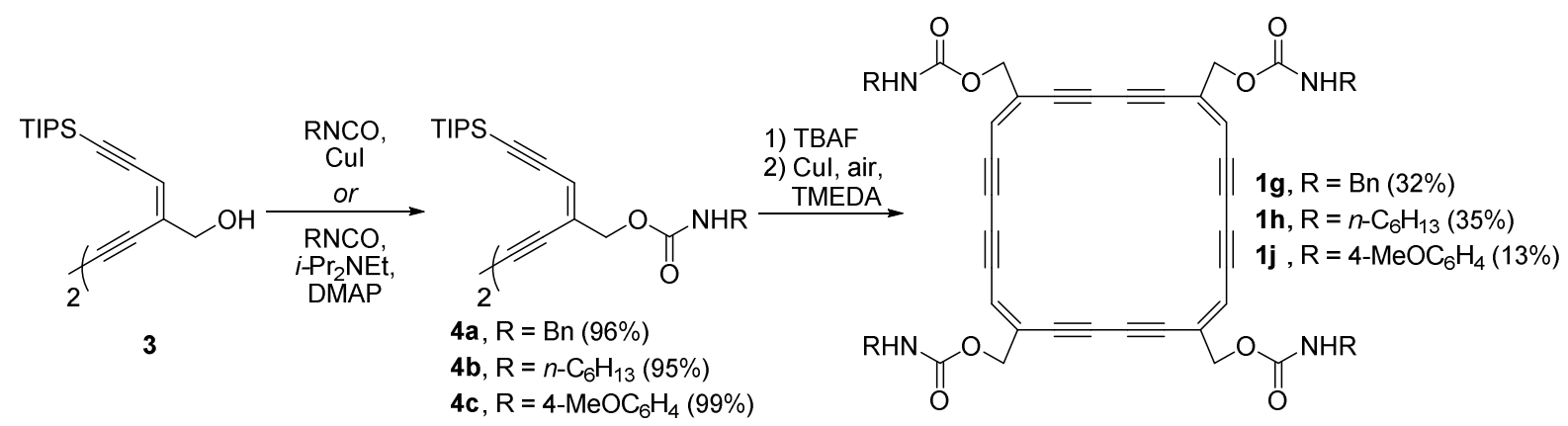


4-(t-Butyldimethylsilyloxy)benzoic acid. A $6 \mathrm{~mL}$ DMF solution containing 4-hydroxybenzoic acid (414 mg, $3.00 \mathrm{mmol}), t$-butyldimethylsilyl chloride $(1.37 \mathrm{~g}, 9.06 \mathrm{mmol})$, and imidazole $(614 \mathrm{mg}, 9.01$ mmol) was stirred for $20 \mathrm{~h}$ at $25{ }^{\circ} \mathrm{C}$, and poured to a separatory funnel containing $30 \mathrm{~mL}$ of Et $2 \mathrm{O}$ and 15 $\mathrm{mL}$ of water. The organic phase was washed with water $(3 \times 10 \mathrm{~mL})$, dried over $\mathrm{MgSO}_{4}$, filtered, and evaporated to afford a pale yellow oil, which was purified by flash silica gel column chromatography $\left(\mathrm{CH}_{2} \mathrm{Cl}_{2}\right)$ to provide $1.05 \mathrm{~g}(96 \%)$ of $t$-butyldimetylsilyl 4-(t-butyldimethylsilyloxy)benzoate as a pale yellow oil.

$t$-Butyldimetylsilyl 4-(t-butyldimethylsilyloxy)benzoate $(1.38 \mathrm{~g}, 3.76 \mathrm{mmol}$, combined with a material from another batch) was dissolved in $15 \mathrm{~mL}$ of THF, $3 \mathrm{~mL}$ of water, and $12 \mathrm{~mL}$ of acetic acid. After stirring at $25^{\circ} \mathrm{C}$ for $20 \mathrm{~h}$ in air, the solution was evaporated to remove THF. The remaining solution was poured to a separatory funnel containing $50 \mathrm{~mL}$ of $\mathrm{Et}_{2} \mathrm{O}$ and $100 \mathrm{~mL}$ of water. The organic phase was isolated, and the aqueous phase was extracted with $50 \mathrm{~mL}$ of $\mathrm{Et}_{2} \mathrm{O}$. The organic layers were combined and evaporated. The resulting material was subjected to flash silica gel chromatography $\left(\mathrm{CH}_{2} \mathrm{Cl}_{2}\right)$ and further purified by recrystallizion from $\mathrm{MeCN}$ to afford $0.667 \mathrm{~g}$ (70\%) of 4-( $t$-butyldimethylsilyloxy)benzoic acid as colorless needles. The structure was confirmed by NMR. ${ }^{\mathrm{S} 3}{ }^{1} \mathrm{H}$ NMR $\left(500 \mathrm{MHz}, \mathrm{CDCl}_{3}\right)$, [ppm]: $0.25(\mathrm{~s}, 6 \mathrm{H}), 1.00(\mathrm{~s}, 9 \mathrm{H}), 6.89(\mathrm{~d}, J=8.6 \mathrm{~Hz}, 2 \mathrm{H}), 8.03(\mathrm{~d}, J=8.6 \mathrm{~Hz}, 2 \mathrm{H}), 12.4\left(\mathrm{br} \mathrm{s}, 0.6 \mathrm{H}^{a}\right) ;{ }^{13} \mathrm{C}\left\{{ }^{1} \mathrm{H}\right\}$ NMR (126 MHz, $\left.\mathrm{CDCl}_{3}\right)$, [ppm]: -4.4, 18.2, 25.6, 119.9, 122.3, 132.3, 160.9, 172.2. ( ${ }^{a}$ This value is not reliable because of significant broadening.)

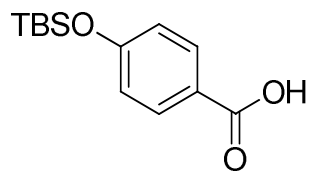

\section{$(1 E, 6 E, 12 E, 18 E)$-Cyclotetracosa-6,12,18,24-tetraen-2,4,8,10,14,16,20,22-octayne-1,6,13,18-}

tetrayltetramethylene tetrakis(4-hydroxybenzoate) (1b). Tetraol 1a (34.3 mg, $82.4 \mu \mathrm{mol})$, DMAP (8.05 mg, $65.9 \mu \mathrm{mol})$, and 4-(t-butyldimethylsilyloxy)benzoic acid (100 mg, $0.396 \mathrm{mmol})$ were dissolved in $5 \mathrm{ml}$ of $\mathrm{CH}_{2} \mathrm{Cl}_{2}$ and $5 \mathrm{ml}$ of THF. The solution was cooled in an ice bath, then $\mathrm{EDC} \cdot \mathrm{HCl}(82.5 \mathrm{mg}$, 
$0.430 \mathrm{mmol}$ ) was added. After stirring at $0-5{ }^{\circ} \mathrm{C}$ for $10 \mathrm{~min}$, the reaction mixture was allowed to warm up and was further stirred at $25^{\circ} \mathrm{C}$ for $12 \mathrm{~h}$. At this point, TLC monitoring indicated that the reaction had not completed $\left(\mathrm{CH}_{2} \mathrm{Cl}_{2} / \mathrm{AcOEt}\right.$, 10:1. Two main spots were observed at $R_{f}=0.6$ and 0.8$)$, and thus additional amounts of 4-(t-butyldimethylsilyloxy)benzoic acid $(50.1 \mathrm{mg}, 0.199 \mathrm{mmol})$ and $\mathrm{EDC} \cdot \mathrm{HCl}(41.1 \mathrm{mg}$, $0.214 \mathrm{mmol}$ ) were added. After the solution was further stirred at $25{ }^{\circ} \mathrm{C}$ for $26 \mathrm{~h}$, TLC indicated the completion of the reaction $\left(\mathrm{CH}_{2} \mathrm{Cl}_{2} / \mathrm{AcOEt}, 10: 1\right.$. Single main spot at $\left.R_{f}=0.8\right)$. The reaction solution was evaporated to give a dark brown solid, which was then subjected to flash silica gel column chromatography $\left(\mathrm{CH}_{2} \mathrm{Cl}_{2}\right.$ /hexanes, $\left.10: 1\right)$ to provide $93.6 \mathrm{mg}(84 \%)$ of $t$-butyldimethylsilyl-protected 4hydroxybenzoate of 1a. ${ }^{1} \mathrm{H}$ NMR (500 MHz, $\mathrm{CDCl}_{3}$ ), [ppm]: 0.23 (s, 24H), 0.99 (s, 36H), 4.87 (s, 8H), $6.26(\mathrm{~s}, 4 \mathrm{H}), 6.87(\mathrm{~d}, J=8.7 \mathrm{~Hz}, 8 \mathrm{H}), 7.96(\mathrm{~d}, J=8.7 \mathrm{~Hz}, 8 \mathrm{H}) ;{ }^{13} \mathrm{C}\left\{{ }^{1} \mathrm{H}\right\} \mathrm{NMR}\left(126 \mathrm{MHz}, \mathrm{CDCl}_{3}\right)$, [ppm]: $-4.4,18.2,25.6,64.7,81.4,81.8,82.7,82.8,118.5,120.0,122.2,131.5,131.8,160.5,165.3$.

The TBS-protected 4-hydroxybenzoate obtained above $(93.6 \mathrm{mg}, 69.1 \mu \mathrm{mol})$ was dissolved in $10 \mathrm{~mL}$ of THF, to which water $(0.20 \mathrm{~mL}), \mathrm{AcOH}$ (glacial, $0.20 \mathrm{~mL}$ ), and TBAF (1.0 M in THF, $0.30 \mathrm{ml}, 0.30$ mmol) were sequentially added. The solution was stirred at $25^{\circ} \mathrm{C}$ for $1 \mathrm{~h}$, and poured to a separatory funnel containing $50 \mathrm{~mL}$ of EtOAc and $15 \mathrm{~mL}$ of $10 \% \mathrm{NH}_{4} \mathrm{Cl}$. The organic phase was isolated, washed with water $(3 \times 15 \mathrm{~mL})$ then brine $(15 \mathrm{~mL})$, dried over $\mathrm{MgSO}_{4}$, filtered, and evaporated to give an orangeyellow solid, which was further purified by filtering through a pad of silica gel $\left(\mathrm{CH}_{2} \mathrm{Cl}_{2} / \mathrm{AcOEt}, 1: 1\right)$ to provide $61.3 \mathrm{mg}(99 \%)$ of $\mathbf{1 b}$ as an orange solid. ${ }^{1} \mathrm{H}$ NMR $\left(500 \mathrm{MHz}, \mathrm{THF}-d_{8}\right),[\mathrm{ppm}]: 4.93$ (s, 8H), 6.75 $(\mathrm{s}, 4 \mathrm{H}), 6.86(\mathrm{~d}, J=8.6 \mathrm{~Hz}, 8 \mathrm{H}), 7.85(\mathrm{~d}, J=8.6 \mathrm{~Hz}, 8 \mathrm{H}), 10.44(\mathrm{~s}, 4 \mathrm{H}) ;{ }^{13} \mathrm{C}\left\{{ }^{1} \mathrm{H}\right\}$ NMR $(126 \mathrm{MHz}, \mathrm{THF}-$ $\left.d_{8}\right),[\mathrm{ppm}]: 64.2,80.8,81.2,81.8,82.4,115.4,119.3,119.9,131.7,132.3,162.3,164.7 ; \mathrm{IR}(\mathrm{KBr}), \bar{v}_{\max }$ [cm $\left.{ }^{-1}\right]: 3311$ (br m), 3062 (w), $2978(w), 2951(w), 2875(w), 2187(w), 2148(w), 2125(w), 1722(s)$, 1693 (m), 1608 (s), 1591 (s), 1514 (m), 1448 (m), 1263 (s), 1238 (s), 1165 (s), 1097 (s); UV-Vis (MeCN), $\lambda_{\max }[\mathrm{nm}]\left(\varepsilon\left[\mathrm{M}^{-1} \cdot \mathrm{cm}^{-1}\right]\right): 260$ (94 100), 309 (28 100), 331 (35 400), 352 (38 000); MS (MALDI-TOF, reflector mode, 2,5-dihydroxybenzoic acid), $m / z$ (\% relative intensity, ion): $919.0\left(100,[\mathrm{M}+\mathrm{Na}]^{+}\right), 935.0$ $\left(32,[\mathrm{M}+\mathrm{K}]^{+}\right)$. 


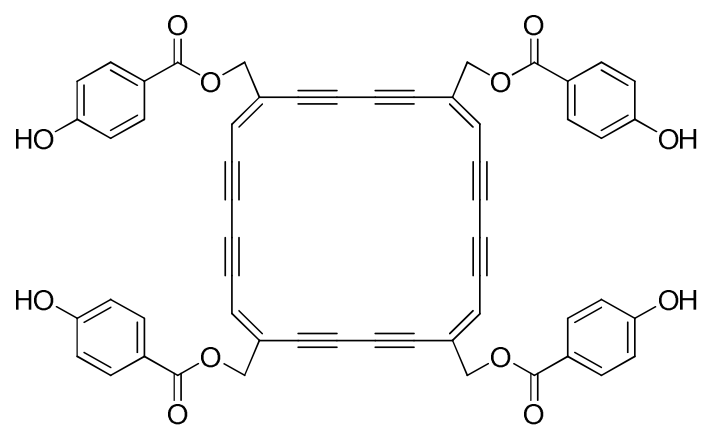

3-(t-Butyldimethylsilyloxy)benzoic acid. 3-Hydoroxybenzoic acid $(1.38 \mathrm{~g}, 10.0 \mathrm{mmol}), t$ butyldimethylsilyl chloride (4.52 g, $30.0 \mathrm{mmol})$, and imidazole $(2.08 \mathrm{~g}, 30.5 \mathrm{mmol})$ were dissolved in 20 $\mathrm{mL}$ of DMF. The solution was stirred at $25^{\circ} \mathrm{C}$ for $24 \mathrm{~h}$, and poured to a separatory funnel containing 100 $\mathrm{mL}$ of $\mathrm{Et}_{2} \mathrm{O}$ and $50 \mathrm{~mL}$ of water. The organic phase was washed with $25 \mathrm{~mL}$ of water, dried over $\mathrm{MgSO}_{4}$, filtered, and evaporated to afford a pale yellow oil. The crude product was subjected to flash silica gel column chromatography $\left(\mathrm{CH}_{2} \mathrm{Cl}_{2}\right)$ to provide $3.68 \mathrm{~g}$ of a pale yellow oil containing $t$-butyldimetylsilyl 3( $t$-butyldimethylsilyloxy)benzoate and $t$-butyldimethylsilanol in a molar ratio of approximately 2:1 (estimated based on ${ }^{1} \mathrm{H}$ NMR integrals).

The mixture obtained above was dissolved in $15 \mathrm{~mL}$ of THF, $3 \mathrm{~mL}$ of water, and $12 \mathrm{~mL}$ of acetic acid. After stirring at $25{ }^{\circ} \mathrm{C}$ for $21 \mathrm{~h}$ in air, the solution was poured to a separatory funnel containing $100 \mathrm{~mL}$ of $\mathrm{Et}_{2} \mathrm{O}$ and $50 \mathrm{~mL}$ of water. The organic phase was isolated, and the aqueous phase was extracted with $\mathrm{Et}_{2} \mathrm{O}$ $(2 \times 50 \mathrm{~mL})$. The organic layers were combined, dried over $\mathrm{MgSO}_{4}$, filtered, and evaporated. The resulting light yellow liquid was subjected to flash silica gel chromatography $\left(\mathrm{CH}_{2} \mathrm{Cl}_{2} \rightarrow \mathrm{CH}_{2} \mathrm{Cl}_{2} / \mathrm{AcOEt}_{\text {, }}\right.$ 10:1), and further purified by recrystallizion from $\mathrm{MeCN}$ to afford $1.66 \mathrm{~g}(66 \%$ over two steps) of 3-(tbutyldimethylsilyloxy)benzoic acid as colorless needles. The structure was confirmed by NMR. ${ }^{\mathrm{S} 4} \mathrm{H}$ NMR (500 MHz, $\left.\mathrm{CDCl}_{3}\right),[\mathrm{ppm}]: 0.24(\mathrm{~s}, 6 \mathrm{H}), 1.01(\mathrm{~s}, 9 \mathrm{H}), 7.10(\mathrm{dd}, J=8.0,1.7 \mathrm{~Hz}, 1 \mathrm{H}), 7.34(\mathrm{t}, J=7.9$ $\mathrm{Hz}, 1 \mathrm{H}), 7.59(\mathrm{~s}, 1 \mathrm{H}), 7.74(\mathrm{~d}, J=7.7 \mathrm{~Hz}, 1 \mathrm{H}), 12.2\left(\right.$ br s, $\left.0.8 \mathrm{H}^{a}\right) ;{ }^{13} \mathrm{C}\left\{{ }^{1} \mathrm{H}\right\}$ NMR $\left(126 \mathrm{MHz}, \mathrm{CDCl}_{3}\right)$, [ppm]: $-4.5,18.2,25.6,119.9,121.5,123.2,125.8,129.5,130.6,155.8,172.3 .\left({ }^{a}\right.$ Smaller than the expected value of one because of significant broadening.) 


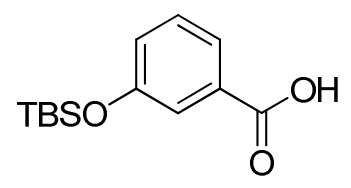

\section{$(1 E, 6 E, 12 E, 18 E)$-cyclotetracosa-6,12,18,24-tetraen-2,4,8,10,14,16,20,22-octayne-1,6,13,18-}

tetrayltetramethylene tetrakis(3-hydroxybenzoate) (1c). Tetraol 1a $(35.0 \mathrm{mg}, 84.0 \mu \mathrm{mol})$, DMAP (8.21 mg, $67.2 \mu \mathrm{mol})$, and benzoic acid 3-(t-butyldimethylsilyloxy)benzoic acid (103 mg, $0.407 \mathrm{mmol})$ were dissolved in $5 \mathrm{ml}$ of $\mathrm{CH}_{2} \mathrm{Cl}_{2}$ and $5 \mathrm{ml}$ of THF. $\mathrm{EDC} \cdot \mathrm{HCl}(84.3 \mathrm{mg}, 0.440 \mathrm{mmol})$ was added to the solution at $0{ }^{\circ} \mathrm{C}$. After stirring at $0-5{ }^{\circ} \mathrm{C}$ for $10 \mathrm{~min}$, the reaction mixture was allowed to warm up and was stirred at $25^{\circ} \mathrm{C}$ for $14 \mathrm{~h}$. The reaction solution was evaporated to give a dark brown solid, which was then subjected to flash silica gel column chromatography $\left(\mathrm{CH}_{2} \mathrm{Cl}_{2} /\right.$ hexanes, 10:1) to provide $114 \mathrm{mg}$ (quant) of $t$-butyldimethylsilyl-protected 3-hydroxybenzoate of 1a. ${ }^{1} \mathrm{H} \mathrm{NMR}\left(500 \mathrm{MHz}, \mathrm{CDCl}_{3}\right),[\mathrm{ppm}]$ : $0.22(\mathrm{~s}, 24 \mathrm{H}), 0.99(\mathrm{~s}, 36 \mathrm{H}), 4.89(\mathrm{~s}, 8 \mathrm{H}), 6.26(\mathrm{~s}, 4 \mathrm{H}), 7.06(\mathrm{~d}, J=8.0 \mathrm{~Hz}, 4 \mathrm{H}), 7.30(\mathrm{t}, J=7.9 \mathrm{~Hz}, 4 \mathrm{H})$, $7.51(\mathrm{~s}, 4 \mathrm{H}), 7.65(\mathrm{~d}, J=7.7 \mathrm{~Hz}, 4 \mathrm{H}) ;{ }^{13} \mathrm{C}\left\{{ }^{1} \mathrm{H}\right\} \mathrm{NMR}\left(126 \mathrm{MHz}, \mathrm{CDCl}_{3}\right),[\mathrm{ppm}]:-4.5,18.1,25.6,65.0$, $81.3,81.8,82.7,82.8,118.7,121.1,122.7,125.3,129.5,130.5,131.2,155.8,165.3$.

The $t$-butyldimethylsilyl-protected 3-hydroxybenzoate obtained above (114 $\mathrm{mg}, 84.2 \mu \mathrm{mol})$ was dissolved in $10 \mathrm{~mL}$ of THF, to which water $(0.20 \mathrm{~mL})$, AcOH (glacial, $0.20 \mathrm{~mL})$, and TBAF $(1.0 \mathrm{M}$ in THF, $0.37 \mathrm{ml}, 0.37 \mathrm{mmol}$ ) were sequentially added. The solution was stirred at $25^{\circ} \mathrm{C}$ for $1 \mathrm{~h}$, and poured to a separatory funnel containing $50 \mathrm{~mL}$ of AcOEt and $15 \mathrm{~mL}$ of $10 \% \mathrm{NH}_{4} \mathrm{Cl}$. The organic phase was isolated, washed with water $(3 \times 15 \mathrm{~mL})$ and brine $(15 \mathrm{~mL})$, dried over $\mathrm{MgSO}_{4}$, filtered, and evaporated to give a yellow-orange solid, which was further purified by flash silica gel column chromatography $\left(\mathrm{CH}_{2} \mathrm{Cl}_{2} / \mathrm{THF}, 5: 1\right)$ to provide $74.8 \mathrm{mg}(99 \%)$ of $1 \mathrm{c}$ as an orange solid. ${ }^{1} \mathrm{H}$ NMR (500 MHz, acetone- $\left.d_{6}\right)$, [ppm]: 4.99 (s, 8H), $6.60(\mathrm{~s}, 4 \mathrm{H}), 7.11(\mathrm{ddd}, J=8.1,2.6,1.1 \mathrm{~Hz}, 4 \mathrm{H}), 7.34(\mathrm{t}, J=7.9 \mathrm{~Hz}, 4 \mathrm{H}), 7.51(\mathrm{dd}, J$ $=2.6,1.6 \mathrm{~Hz}, 4 \mathrm{H}), 7.54(\mathrm{dt}, J=7.7,1.4 \mathrm{~Hz}, 4 \mathrm{H}), 8.73(\mathrm{br} \mathrm{s}, 4 \mathrm{H}) ;{ }^{13} \mathrm{C}\left\{{ }^{1} \mathrm{H}\right\}$ NMR $\left(126 \mathrm{MHz}\right.$, acetone- $\left.d_{6}\right)$, [ppm]: $65.7,82.3,82.4,82.5,82.9,117.0,120.3,121.5,121.7,130.7,131.7,133.2,158.4,166.0$; IR (KBr), $\bar{v}_{\max }\left[\mathrm{cm}^{-1}\right]: 3373$ (br m), $3030(\mathrm{w}), 2945$ (w), 2193 (w), $2175(\mathrm{w}), 2125(\mathrm{w}), 1701$ (s), $1603(\mathrm{~m})$, 
$1589(\mathrm{~m}), 1454$ (m), 1286 (s), 1215 (s), 1103 (m), 1074 (m); UV-vis (MeOH), $\lambda_{\max }[\mathrm{nm}]\left(\varepsilon\left[\mathrm{M}^{-1} \cdot \mathrm{cm}^{-1}\right]\right)$ : 306 (36 500), 330 (36 500), 352 nm (39 100); MALDI-TOF MS (reflector mode, 2,5-dihydroxybenzoic acid), $m / z$ (\% relative intensity, ion): $919.0\left(100,[\mathrm{M}+\mathrm{Na}]^{+}\right), 935.0\left(39,[\mathrm{M}+\mathrm{K}]^{+}\right)$.

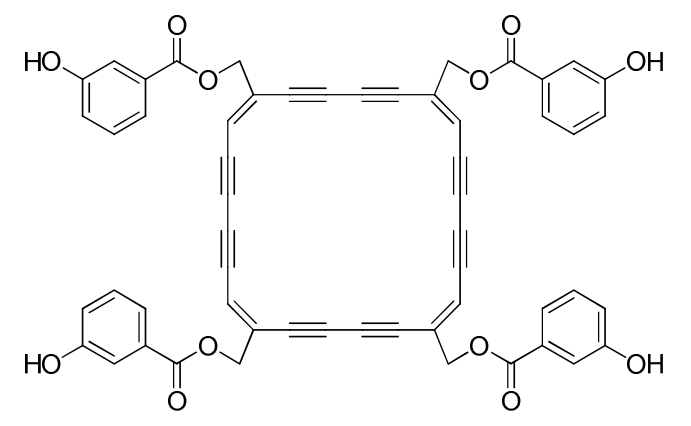

3,5-Bis(t-butyldimethylsilyloxy)benzoic acid. 3,5-Dihydoroxybenzoic acid (1.55 g, $10.0 \mathrm{mmol}), t$ butyldimethylsilyl chloride (6.16 g, $40.8 \mathrm{mmol})$, and imidazole $(2.72 \mathrm{~g}, 40.0 \mathrm{mmol})$ were dissolved in 20 $\mathrm{mL}$ of DMF. The solution was stirred at $25^{\circ} \mathrm{C}$ for $21 \mathrm{~h}$, and poured to a separatory funnel containing 100 $\mathrm{mL}$ of $\mathrm{Et}_{2} \mathrm{O}$ and $50 \mathrm{~mL}$ of water. The organic phase was washed with water $(2 \times 25 \mathrm{~mL})$, dried over $\mathrm{MgSO}_{4}$, filtered, and evaporated to afford a colorless liquid containing a small amount of white solid. The crude product was purified by flash silica gel column chromatography (hexanes $/ \mathrm{CH}_{2} \mathrm{Cl}_{2}, 4: 1$ then $8: 3$ ) to provide $3.82 \mathrm{~g}(77 \%)$ of $t$-butyldimetylsilyl 3,5-bis(t-butyldimethylsilyloxy)benzoate as a white solid.

The intermediate obtained above was dissolved in $15 \mathrm{~mL}$ of THF, $3 \mathrm{~mL}$ of water, and $12 \mathrm{~mL}$ of glacial $\mathrm{AcOH}$. After stirring at $25^{\circ} \mathrm{C}$ for $24 \mathrm{~h}$ in air, the solution was poured to a separatory funnel containing $100 \mathrm{~mL}$ of $\mathrm{Et}_{2} \mathrm{O}$ and $50 \mathrm{~mL}$ of water. The organic phase was isolated, and the aqueous phase was extracted with $\mathrm{Et}_{2} \mathrm{O}(2 \times 50 \mathrm{~mL})$. The organic layers were combined, dried over $\mathrm{MgSO}_{4}$, filtered, and evaporated. The resulting pale yellow solid was further purified by recrystallizion from $\mathrm{MeCN}$ to afford $2.78 \mathrm{~g}(95 \%)$ of 3,5-bis(t-butyldimethylsilyloxy)benzoic acid as colorless needles. The structure was confirmed by NMR. ${ }^{\mathrm{S} 5}{ }^{1} \mathrm{H}$ NMR (500 MHz, $\left.\mathrm{CDCl}_{3}\right),[\mathrm{ppm}]: 0.22$ (s, 12H), 0.99 (s, 18H), 6.59 (t, $J=2.2$ $\mathrm{Hz}, 1 \mathrm{H}), 7.21(\mathrm{~d}, J=2.2 \mathrm{~Hz}, 2 \mathrm{H}), 11.9\left(\mathrm{br} \mathrm{s}, 0.5 \mathrm{H}^{a}\right) ;{ }^{13} \mathrm{C}\left\{{ }^{1} \mathrm{H}\right\} \mathrm{NMR}\left(126 \mathrm{MHz}, \mathrm{CDCl}_{3}\right),[\mathrm{ppm}]:-4.4,18.2$, $25.6,115.1,117.8,130.9,156.6,172.1$. 
${ }^{a}$ Smaller than the expected value of one because of significant broadening.

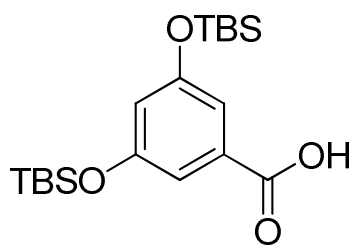

\section{$(1 E, 6 E, 12 E, 18 E)$-Cyclotetracosa-6,12,18,24-tetraen-2,4,8,10,14,16,20,22-octayne-1,6,13,18-}

tetrayltetramethylene tetrakis(3,5-dihydroxybenzoate) (1d). Tetraol 1a (42.1 mg, $101 \mu \mathrm{mol})$, DMAP (9.88 mg, $80.9 \mu \mathrm{mol})$, and 3,5-bis(t-butyldimethylsilyloxy)benzoic acid (186 mg, $0.487 \mathrm{mmol})$ were dissolved in $5 \mathrm{ml}$ of $\mathrm{CH}_{2} \mathrm{Cl}_{2}$ and $5 \mathrm{ml}$ of THF. $\mathrm{EDC} \cdot \mathrm{HCl}(101.4 \mathrm{mg}, 0.529 \mathrm{mmol})$ was added to the solution at $0{ }^{\circ} \mathrm{C}$. After stirring at $0-5{ }^{\circ} \mathrm{C}$ for $10 \mathrm{~min}$, the reaction mixture was allowed to warm up and stirred at $25{ }^{\circ} \mathrm{C}$ for $15 \mathrm{~h}$. The reaction solution was evaporated to give a dark brown solid, which was subjected to flash silica gel column chromatography $\left(\mathrm{CH}_{2} \mathrm{Cl}_{2} /\right.$ hexanes, $\left.2: 1\right)$ to provide $178 \mathrm{mg}(94 \%)$ of $t$ butyldimethylsilyl-protected 3,5-dihydroxybenzoate of 1a. ${ }^{1} \mathrm{H}$ NMR (500 MHz, $\mathrm{CDCl}_{3}$ ), [ppm]: 0.22 (s, $48 \mathrm{H}), 0.98(\mathrm{~s}, 72 \mathrm{H}), 4.87(\mathrm{~s}, 8 \mathrm{H}), 6.25(\mathrm{~s}, 4 \mathrm{H}), 6.55(\mathrm{t}, J=2.0 \mathrm{~Hz}, 4 \mathrm{H}), 7.14(\mathrm{~d}, J=2.0 \mathrm{~Hz}, 8 \mathrm{H}) ;{ }^{13} \mathrm{C}\left\{{ }^{1} \mathrm{H}\right\}$ NMR (126 MHz, $\left.\mathrm{CDCl}_{3}\right),[\mathrm{ppm}]:-4.4,18.2,25.6,65.0,81.2,81.7,82.7,82.8,114.6,117.4,118.5,130.8$, $131.3,156.7,165.2$.

The $t$-butyldimetylsilyl-protected 3,5-dihydroxybenzoate obtained above (175 $\mathrm{mg}, 93.4 \mu \mathrm{mol})$ was dissolved in $20 \mathrm{~mL}$ of THF, to which water $(0.50 \mathrm{~mL})$, AcOH (glacial, $0.50 \mathrm{~mL})$, and TBAF $(1.0 \mathrm{M}$ in THF, $0.82 \mathrm{ml}, 0.82 \mathrm{mmol}$ ) were sequentially added. After stirring at $25^{\circ} \mathrm{C}$ for $2 \mathrm{~h}$ in air, the solution was evaporated to dryness and filtered through a pad of silica gel with the aid of $\mathrm{CH}_{2} \mathrm{Cl}_{2} / \mathrm{MeOH}(5: 1)$ as eluent. The resulting material was further purified by flash silica gel column chromatography $\left(\mathrm{CH}_{2} \mathrm{Cl}_{2} \rightarrow\right.$ $\left.\mathrm{CH}_{2} \mathrm{Cl}_{2} / \mathrm{MeOH}, 5: 1 \rightarrow \mathrm{THF}\right)$ to provide $79.5 \mathrm{mg}(89 \%)$ of $\mathbf{1 d}$ as an orange powder. ${ }^{1} \mathrm{H}$ NMR (500 MHz, DMSO-d $\left.)_{6}\right),[\mathrm{ppm}]: 4.93(\mathrm{~s}, 8 \mathrm{H}), 6.47(\mathrm{t}, J=1.9 \mathrm{~Hz}, 4 \mathrm{H}), 6.74(\mathrm{~s}, 4 \mathrm{H}), 6.85(\mathrm{~d}, J=2.1 \mathrm{~Hz}, 8 \mathrm{H}), 9.68(\mathrm{~s}$, $8 \mathrm{H}) ;{ }^{13} \mathrm{C}\left\{{ }^{1} \mathrm{H}\right\}$ NMR (126 MHz, DMSO-d $d_{6}$, [ppm]: 64.7, 80.9, 81.4, 81.9, 82.6, 107.3, 107.7, 120.2, 130.5, 132.1, 158.7, 165.0; IR (KBr), $\bar{v}_{\max }\left[\mathrm{cm}^{-1}\right]: 3361$ (s), 3045 (w), $2979(\mathrm{w}), 2935(\mathrm{w}), 2873(\mathrm{w}), 2189(\mathrm{w})$, 
$2171(\mathrm{w}), 2125$ (w), 1705 (s), 1603 (s), 1483 (m), 1452 (s), 1390(m), 1375 (s), 1346 (s), 1288 (s), 1234 (s), $1165(\mathrm{~s}), 1105(\mathrm{~m}), 1043(\mathrm{~m}), 1007$ (s); UV-vis (MeOH), $\lambda_{\max }[\mathrm{nm}]\left(\varepsilon\left[\mathrm{M}^{-1} \cdot \mathrm{cm}^{-1}\right]\right): 253(53100), 311$ (27 000), 330 (30 100), 351 (28 200); MS (MALDI-TOF, reflector mode, 2,5-dihydroxybenzoic acid), $m / z$ (\% relative intensity, ion): $983.0\left(100,[\mathrm{M}+\mathrm{Na}]^{+}\right), 999.1\left(13,[\mathrm{M}+\mathrm{K}]^{+}\right)$.

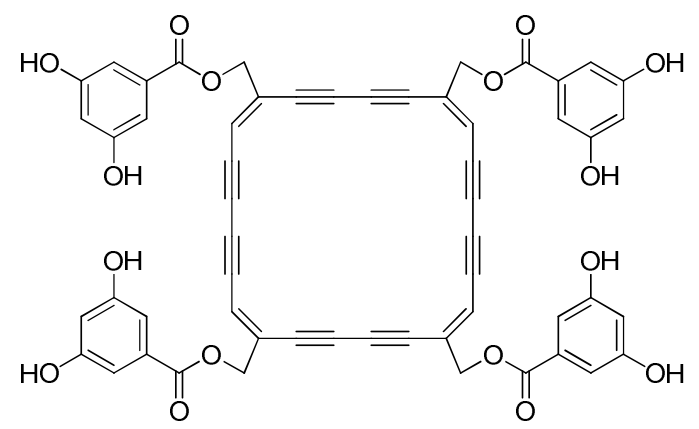

$(1 E, 6 E, 12 E, 18 E)$-cyclotetracosa-6,12,18,24-tetraen-2,4,8,10,14,16,20,22-octayne-1,6,13,18-

tetrayltetramethylene tetrakis(4-iodobenzoate) (1e). Tetraol 1a (37.3 mg, $89.6 \mu \mathrm{mol})$, DMAP (8.68 mg, $71.0 \mu \mathrm{mol})$, and 4-iodobenzoic acid $(107 \mathrm{mg}, 0.431 \mathrm{mmol})$ were dissolved in $5 \mathrm{ml}$ of $\mathrm{CH}_{2} \mathrm{Cl}_{2}$ and $5 \mathrm{ml}$ of THF, then $\mathrm{EDC} \cdot \mathrm{HCl}(89.3 \mathrm{mg}, 0.466 \mathrm{mmol})$ was added to the solution at $0{ }^{\circ} \mathrm{C}$. After stirring at $0-5{ }^{\circ} \mathrm{C}$ for $10 \mathrm{~min}$, the reaction mixture was allowed to warm up and was further stirred at $25^{\circ} \mathrm{C}$ for $13 \mathrm{~h}$ to form a yellow precipitate. The mixture was diluted with $500 \mathrm{~mL}$ of $\mathrm{CH}_{2} \mathrm{Cl}_{2}$ to dissolve all the precipitate, washed with $100 \mathrm{~mL}$ of sat. $\mathrm{NH}_{4} \mathrm{Cl}$, dried over $\mathrm{MgSO}_{4}$, filtered, and evaporated. The resulting yellow powder was dispersed in $\mathrm{CH}_{2} \mathrm{Cl}_{2}$ with sonication and precipitated by adding acetone to provide $103 \mathrm{mg}(86 \%)$ of $\mathbf{1 e}$ as a light yellow powder. ${ }^{1} \mathrm{H}$ NMR (500 MHz, THF- $\left.d_{8}\right)$, [ppm]: $4.91(\mathrm{~s}, 8 \mathrm{H}), 6.49(\mathrm{~s}, 4 \mathrm{H}), 7.77(\mathrm{~d}, J=8.5$ $\mathrm{Hz}, 8 \mathrm{H}), 7.87(\mathrm{~d}, J=8.5 \mathrm{~Hz}, 8 \mathrm{H}) ;{ }^{13} \mathrm{C}\left\{{ }^{1} \mathrm{H}\right\} \mathrm{NMR}\left(126 \mathrm{MHz}, \mathrm{THF}-d_{8}\right),[\mathrm{ppm}]: 66.2,82.4,82.7,82.9,83.0$, 101.9, 120.4, 130.2, 132.0, 132.7, 138.9, 165.6; IR (KBr), $\bar{v}_{\max }\left[\mathrm{cm}^{-1}\right]: 3089(\mathrm{w}), 3032(\mathrm{w}), 2933(\mathrm{w})$, $2873(w), 2193(w), 2125(w), 1730(s), 1720(s), 1583(\mathrm{~m}), 1392(\mathrm{~m}), 1265$ (s), $1176(\mathrm{~m}), 1114(\mathrm{~s}), 1101$ (s), 1007 (m); UV-vis $\left(\mathrm{CHCl}_{3}\right), \lambda_{\max }[\mathrm{nm}]\left(\varepsilon\left[\mathrm{M}^{-1} \cdot \mathrm{cm}^{-1}\right]\right): 313$ (30 100), 335 (41 200), 357 (46 900); MS (MALDI-TOF, reflector mode, 2,5-dihydroxybenzoic acid), $m / z$ (\% relative intensity, ion): 1358.4 (100, $\left.[\mathrm{M}+\mathrm{Na}]^{+}\right)$. 


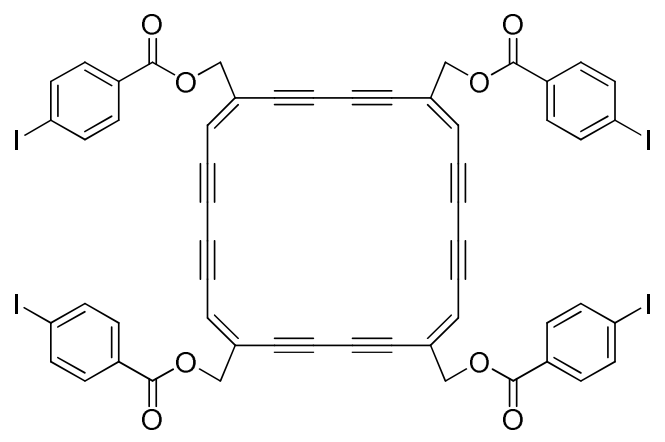

$(1 E, 6 E, 12 E, 18 E)$-Cyclotetracosa-6,12,18,24-tetraen-2,4,8,10,14,16,20,22-octayne-1,6,13,18-

tetrayltetramethylene tetrakis(3-iodobenzoate) (1f). Tetraol 1a $(32.0 \mathrm{mg}, 76.8 \mu \mathrm{mol})$, DMAP (7.48 mg, $61.2 \mu \mathrm{mol})$, and 3-iodobenzoic acid $(92.6 \mathrm{mg}, 0.373 \mathrm{mmol})$ were dissolved in $5 \mathrm{ml}$ of $\mathrm{CH}_{2} \mathrm{Cl}_{2}$ and $5 \mathrm{ml}$ of THF, then $\mathrm{EDC} \cdot \mathrm{HCl}(78.5 \mathrm{mg}, 0.409 \mathrm{mmol})$ was added to the solution at $0{ }^{\circ} \mathrm{C}$. After stirring at $0-5{ }^{\circ} \mathrm{C}$ for $15 \mathrm{~min}$, the reaction mixture was allowed to warm up and was further stirred at $25^{\circ} \mathrm{C}$ for $16.5 \mathrm{~h}$, and evaporated to give a dark brown solid. The crude product was subjected to flash silica gel column chromatography $\left(\mathrm{CH}_{2} \mathrm{Cl}_{2} /\right.$ hexanes, 5:1) to provide $93.2 \mathrm{mg}(91 \%)$ of $\mathbf{1 f}$ as a yellow powder. ${ }^{1} \mathrm{H}$ NMR (500 MHz, $\left.\mathrm{CDCl}_{3}\right),[\mathrm{ppm}]: 4.89$ (s, 8H), $6.25(\mathrm{~s}, 4 \mathrm{H}), 7.18$ (t, J= 7.9 Hz, 4H), 7.89 (d, J= $\left.7.9 \mathrm{~Hz}, 4 \mathrm{H}\right)$, $8.00(\mathrm{~d}, J=7.8 \mathrm{~Hz}, 4 \mathrm{H}), 8.36(\mathrm{~s}, 4 \mathrm{H}) ;{ }^{13} \mathrm{C}\left\{{ }^{1} \mathrm{H}\right\} \mathrm{NMR}\left(126 \mathrm{MHz}, \mathrm{CDCl}_{3}\right),[\mathrm{ppm}]:$ 65.2, 81.3, 81.8, 82.7, $82.9,93.8,119.1,128.8,130.0,130.8,131.0,138.4,142.1,164.0 ; \mathrm{IR}(\mathrm{KBr}), \bar{v}_{\max }\left[\mathrm{cm}^{-1}\right]: 3060(\mathrm{w}), 3039$ (w), $2966(\mathrm{w}), 2929(\mathrm{w}), 2195(\mathrm{w}), 2127(\mathrm{w}), 1730(\mathrm{~s}), 1564(\mathrm{~m}), 1290(\mathrm{~m}), 1250(\mathrm{~s}), 1122(\mathrm{~m}), 1103(\mathrm{~m})$, $1082(\mathrm{~m}), 1059(\mathrm{~m}), 997(\mathrm{~m}) ; \mathrm{UV}-\mathrm{vis}\left(\mathrm{CHCl}_{3}\right), \lambda_{\max }[\mathrm{nm}]\left(\varepsilon\left[\mathrm{M}^{-1} \cdot \mathrm{cm}^{-1}\right]\right): 351$ (49 800); MS (MALDITOF, reflector mode, 2,5-dihydroxybenzoic acid), $m / z$ (\% relative intensity, ion): $1358.5\left(100,[\mathrm{M}+\mathrm{Na}]^{+}\right)$, $1374.5\left(22,[\mathrm{M}+\mathrm{K}]^{+}\right)$; HRMS (ESI) $m / z$ calcd for $\mathrm{C}_{56} \mathrm{H}_{28} \mathrm{I}_{4} \mathrm{O}_{8} \mathrm{Na}[\mathrm{M}+\mathrm{Na}]^{+}$: 1358.7855 , found: 1358.7805. 


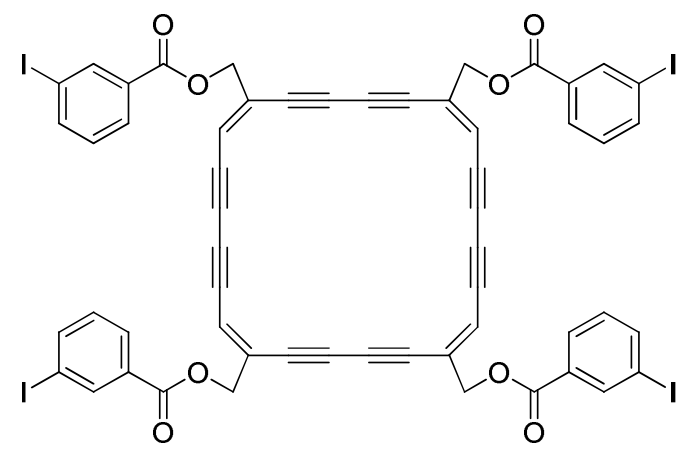

\section{(2E,7E)-2,7-Bis(3-(triisopropylsilyl)prop-2-ynylidene)octa-3,5-diyne-1,8-diyl}

bis(benzylcarbamate) (4a). Diol 3 (200 mg, $0.382 \mathrm{mmol})$ and DMAP (9.37 mg, $76.7 \mu \mathrm{mol})$ were dissolved in $5 \mathrm{ml}$ of $\mathrm{CH}_{2} \mathrm{Cl}_{2}$, to which $i-\mathrm{Pr}_{2} \mathrm{NEt}(235 \mu \mathrm{l}, 1.35 \mathrm{mmol})$ and benzyl isocyanate $(165 \mu \mathrm{l}, 1.35$ mmol) were sequentially added. After stirring at $25^{\circ} \mathrm{C}$ for $17.5 \mathrm{~h}$, the solution was poured to a separatory funnel containing $25 \mathrm{~mL}$ of AcOEt and $10 \mathrm{~mL}$ of $10 \% \mathrm{NH}_{4} \mathrm{Cl}$. The organic phase was washed with water $(3 \times 10 \mathrm{~mL})$ then brine $(10 \mathrm{~mL})$, dried over $\mathrm{MgSO}_{4}$, and evaporated. The resulting oil was purified by flash silica gel column chromatography $\left(\mathrm{CH}_{2} \mathrm{Cl}_{2} / \mathrm{AcOEt}\right.$, 200:3 then 50:1) to afford $290 \mathrm{mg}$ (96\%) of 4a as a light yellow oil, which gradually turned into a pale yellow waxy solid. ${ }^{1} \mathrm{H}$ NMR $\left(500 \mathrm{MHz}, \mathrm{CDCl}_{3}\right)$, [ppm]: $1.10(\mathrm{~s}, 42 \mathrm{H}), 4.38(\mathrm{~d}, J=5.8 \mathrm{~Hz}, 4 \mathrm{H}), 4.65$ (s, 4H), 4.97 and 5.13 (two br s, 2H in total), 5.96, 6.10 (two s, $2 \mathrm{H}$ in total), 7.26-7.35 (m, 10H); ${ }^{13} \mathrm{C}\left\{{ }^{1} \mathrm{H}\right\}$ NMR (126 MHz, $\mathrm{CDCl}_{3}$ ), [ppm]: 11.1, 18.5, 45.1, $65.2,80.6,81.3,102.1,103.0,120.4,127.4,127.5,128.6,129.1,138.0,155.4 ; \mathrm{IR}(\mathrm{KBr}), \bar{v}_{\max }\left[\mathrm{cm}^{-1}\right]: 3305$ (s), 3090 (w), 3067 (w), 3033 (w), 2942 (s), 2890 (m), 2846 (s), 2193 (w), $2139(\mathrm{w}), 1696(\mathrm{~s}), 1530(\mathrm{~m})$, $1459(\mathrm{~m}), 1241$ (s), $1048(\mathrm{~m}) ; \mathrm{UV}-\mathrm{vis}$ (cyclohexane), $\lambda_{\max }[\mathrm{nm}]\left(\varepsilon\left[\mathrm{M}^{-1} \cdot \mathrm{cm}^{-1}\right]\right): 299$ (19 300), 319 (21 000), 343 (24 300), 369 (22 400); MS (MALDI-TOF, reflector mode, 2,5-dihydroxybenzoic acid), $m / z$ (\% relative intensity, ion): $811.7\left(100,[\mathrm{M}+\mathrm{Na}]^{+}\right), 827.7\left(53,[\mathrm{M}+\mathrm{K}]^{+}\right)$.

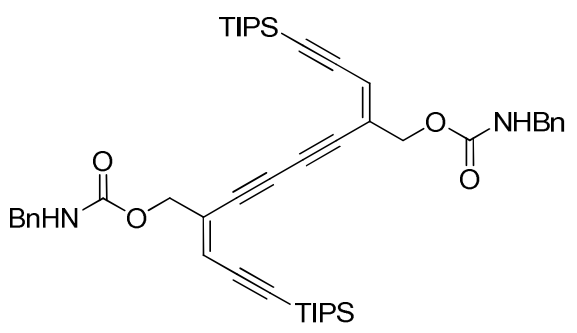


$(1 E, 6 E, 12 E, 18 E)$-Cyclotetracosa-6,12,18,24-tetraen-2,4,8,10,14,16,20,22-octayne-1,6,13,18-

tetrayltetramethylene tetrakis(benzylcarbamate) (1g). The protected precursor 4a $(290 \mathrm{mg}, 0.367$ mmol) was dissolved in $15 \mathrm{~mL}$ of THF, and the solution was cooled in an ice bath. Water $(0.10 \mathrm{~mL})$, AcOH (1.0 $\mathrm{M}$ in THF, $0.81 \mathrm{~mL}, 0.81 \mathrm{mmol})$, and TBAF (1.0 $\mathrm{M}$ in THF, $0.81 \mathrm{~mL}, 0.81 \mathrm{mmol})$ were sequentially added to the solution. After stirring at $0-5{ }^{\circ} \mathrm{C}$ for $30 \mathrm{~min}$, the reaction mixture was poured to a separatory funnel containing $50 \mathrm{~mL}$ of $\mathrm{Et}_{2} \mathrm{O}$ and $15 \mathrm{~mL}$ of $10 \% \mathrm{NH}_{4} \mathrm{Cl}$. The organic phase was washed with water $(3 \times 15 \mathrm{~mL})$ then brine $(15 \mathrm{~mL})$, dried over $\mathrm{MgSO}_{4}$, filtered, and evaporated to $c a$. $10 \mathrm{~mL}$. The solution was diluted with $50 \mathrm{~mL}$ of acetone, and concentrated again to $c a .10 \mathrm{~mL}$. The resulting solution was diluted again with acetone to $365 \mathrm{~mL}\left(c a .1 .0 \times 10^{-3} \mathrm{M}\right)$, to which TMEDA $(0.28 \mathrm{~mL}, 1.9 \mathrm{mmol})$ and $\mathrm{CuI}(140 \mathrm{mg}, 0.732 \mathrm{mmol})$ were added. The solution was stirred at $25^{\circ} \mathrm{C}$ for $17 \mathrm{~h}$ in air, concentrated to ca. $5 \mathrm{~mL}$, and filtered through a pad of silica gel with the aid of $\mathrm{CH}_{2} \mathrm{Cl}_{2} /$ acetone (4:1) as eluent. The filtrate was evaporated to dryness, and the resulting dark brown solid was subjected to flash silica gel column chromatography $\left(\mathrm{CH}_{2} \mathrm{Cl}_{2}\right.$ /acetone, $25: 1$ then 10:1) to provide a dark brown oil. This oil was dissolved in $2 \mathrm{~mL}$ of THF, to which $8 \mathrm{~mL}$ of MeCN was added. The resulting brown solid was removed by filtration through a cotton plug. The filtrate was evaporated to dryness, and further purified through repetitive precipitation from an acetone/ $\mathrm{CH}_{2} \mathrm{Cl}_{2}$ (1:1) solution (twice) then from a $\mathrm{CH}_{2} \mathrm{Cl}_{2}$ solution (twice) by adding petroleum ether. (The solid was only partially dissolved in pure $\mathrm{CH}_{2} \mathrm{Cl}_{2}$, and the undissolved portion was suspended well by sonication before the addition of petroleum ether). All the supernatants were combined, evaporated, and precipitated from a $\mathrm{CH}_{2} \mathrm{Cl}_{2}$ solution by adding $\mathrm{Et}_{2} \mathrm{O}$ (three times) then by adding petroleum ether (twice). The first and second crops were combined and subjected to further precipitation from a $\mathrm{CH}_{2} \mathrm{Cl}_{2}$ solution by adding petroleum ether (twice) to provide $56 \mathrm{mg}(32 \%)$ of $\mathbf{1 g}$ as a light yellow powder. ${ }^{1} \mathrm{H}$ NMR (500 MHz, acetone- $\left.d_{6}\right)$, [ppm]: 4.34 (d, $\left.J=6.1 \mathrm{~Hz}, 8 \mathrm{H}\right), 4.73$ (s, 8H), 6.22, 6.45 (two s, 4H in total), 6.69, 7.03 (two br s, 4H in total), 7.23-7.32 (m, 20H); ${ }^{13} \mathrm{C}\left\{{ }^{1} \mathrm{H}\right\} \mathrm{NMR}(126 \mathrm{MHz}$, acetone- $\left.d_{6}\right)$, [ppm]: 45.4, 65.4, 82.2, 82.4, 82.8, 119.3, 127.9, 128.2, 129.3, 134.4, 140.4, 156.5; IR (KBr), $\bar{v}_{\max }\left[\mathrm{cm}^{-1}\right]: 3410(\mathrm{sh} \mathrm{m}), 3315(\mathrm{~s}), 3086$ (sh w), 3062 (sh w), $3029(\mathrm{~m}), 2931$ (w), 2871 (sh w), $2258(\mathrm{w})$, $2192(\mathrm{w}), 2169$ (w), 2125 (w), 1702 (s), 1524 (s), 1249 (s), 1136 (m), 1040 (m); UV-vis $\left(\mathrm{CHCl}_{3}\right), \lambda_{\max }$ 
[nm] $\left(\varepsilon\left[\mathrm{M}^{-1} \cdot \mathrm{cm}^{-1}\right]\right): 311$ (22 400), 334 (31 200), 356 (35 500); MS (MALDI-TOF, reflector mode, 2,5dihydroxybenzoic acid), $m / z$ (\% relative intensity, ion): $971.6\left(100,[\mathrm{M}+\mathrm{Na}]^{+}\right), 987.6\left(92,[\mathrm{M}+\mathrm{K}]^{+}\right)$.

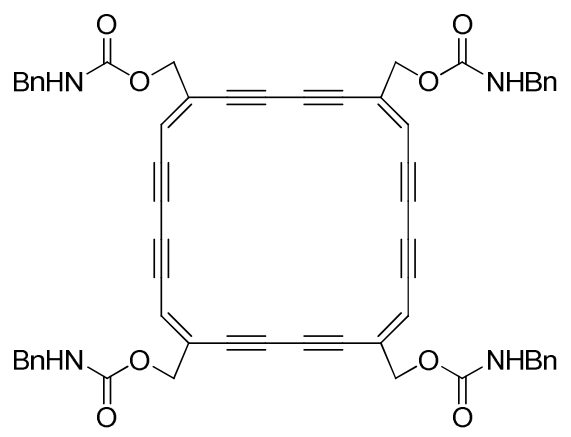

\section{(2E,7E)-2,7-Bis(3-(triisopropylsilyl)prop-2-ynylidene)octa-3,5-diyne-1,8-diyl bis(n-hexylcarba-}

mate) (4b). Diol 3 (105 mg, $0.201 \mathrm{mmol})$ and CuI (119 mg, $0.625 \mathrm{mmol})$ were dissolved in $4 \mathrm{~mL}$ of DMF. After addition of $n$-hexyl isocyanate $(175 \mu \mathrm{l}, 1.21 \mathrm{mmol})$, the solution was stirred at $25^{\circ} \mathrm{C}$ for $3 \mathrm{~h}$, and the reaction was quenched by adding $0.5 \mathrm{~mL}$ of methanol followed by stirring for additional $30 \mathrm{~min}$. The mixture was filtered through a cotton plug to remove most of $\mathrm{CuI}$, and the filtrate was poured to a separatory funnel containing $20 \mathrm{~mL}$ of $\mathrm{Et}_{2} \mathrm{O}$ and $10 \mathrm{~mL}$ of water. The organic layer was isolated, washed with water $(3 \times 10 \mathrm{~mL})$ then brine $(10 \mathrm{~mL})$, dried over $\mathrm{MgSO}_{4}$, filtered, and evaporated to give a yellow oil containing a small amount of white solid. The oil was subjected to flash silica gel column chromatography $\left(\mathrm{CH}_{2} \mathrm{Cl}_{2} / \mathrm{AcOEt}, 50: 1\right)$ to provide $143 \mathrm{mg}(95 \%)$ of $\mathbf{4 b}$ as a yellow waxy solid. ${ }^{1} \mathrm{H} \mathrm{NMR}$ $\left(500 \mathrm{MHz}, \mathrm{CDCl}_{3}\right),[\mathrm{ppm}]: 0.88(\mathrm{t}, J=6.8 \mathrm{~Hz}, 6 \mathrm{H}), 1.09(\mathrm{~s}, 21 \mathrm{H}), 1.25-1.34(\mathrm{~m}, 12 \mathrm{H}), 1.49$ (quintet, $J=$ $6.8 \mathrm{~Hz}, 4 \mathrm{H}), 3.17$ (q, $J=6.7 \mathrm{~Hz}, 4 \mathrm{H}), 4.60(\mathrm{~s}, 4 \mathrm{H}), 4.64,4.74$ (two br s, 2H in total), 6.08 (s, 2H); ${ }^{13} \mathrm{C}\left\{{ }^{1} \mathrm{H}\right\}$ NMR $\left(126 \mathrm{MHz}, \mathrm{CDCl}_{3}\right),[\mathrm{ppm}]: 11.1,13.9,18.5,22.5,26.3,29.8,31.4,41.1,64.9,80.7,81.3$, 101.9, 103.2, 120.2, 129.4, 155.4; IR (KBr), $\bar{v}_{\max }\left[\mathrm{cm}^{-1}\right]: 3303$ (m), $3073(\mathrm{w}), 3039(\mathrm{w}), 2938(\mathrm{~s}), 2864(\mathrm{~s})$, 2189 (w), 2139 (m), 1738 (s), 1709 (s), 1549 (s), 1464 (s), 1379 (m), 1252 (s), 1157 (m), 1132 (m), 1093 (m); UV-vis $\left(\mathrm{CHCl}_{3}\right), \lambda_{\max }[\mathrm{nm}]\left(\varepsilon\left[\mathrm{M}^{-1} \cdot \mathrm{cm}^{-1}\right]\right): 280$ (17 700), 300 (19 000), 320 (19 700), 346 (21 500), 370 (19 300); MS (MALDI-TOF, reflector mode, 2,5-dihydroxybenzoic acid), $\mathrm{m} / z$ (\% relative intensity, ion): $798.9\left(100,[\mathrm{M}+\mathrm{Na}]^{+}\right)$. 


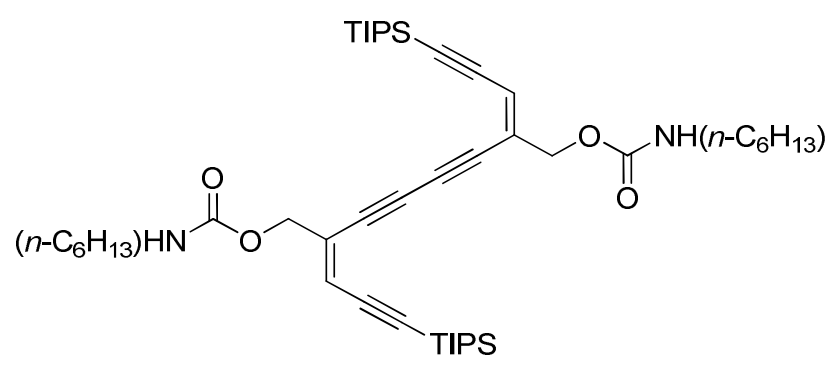

\section{$(1 E, 6 E, 12 E, 18 E)$-Cyclotetracosa-6,12,18,24-tetraen-2,4,8,10,14,16,20,22-octayne-1,6,13,18-}

tetrayltetramethylene tetrakis(n-hexylcarbamate) $\mathbf{( 1 h )}$. The protected precursor $\mathbf{4 b}$ (151 $\mathrm{mg}, 0.194$ mmol) was dissolved in $10 \mathrm{~mL}$ of THF. The solution was cooled in an ice bath, to which AcOH (1.0 M in THF, $0.425 \mathrm{~mL}, 0.425 \mathrm{mmol})$, and TBAF (1.0 M in THF, $0.425 \mathrm{~mL}, 0.425 \mathrm{mmol})$ were sequentially added. After stirring at $0-5{ }^{\circ} \mathrm{C}$ for $30 \mathrm{~min}$, the solution was poured to a separatory funnel containing 30 $\mathrm{mL}$ of $\mathrm{Et}_{2} \mathrm{O}$ and $10 \mathrm{~mL}$ of $10 \% \mathrm{NH}_{4} \mathrm{Cl}$. The organic phase was isolated, washed with water $(3 \times 10 \mathrm{~mL})$ then brine $(10 \mathrm{~mL})$, dried over $\mathrm{MgSO}_{4}$, filtered, and evaporated to about $10 \mathrm{~mL}$. The solution was diluted with $30 \mathrm{~mL}$ of acetone, concentrated to about $10 \mathrm{~mL}$ and diluted again to $195 \mathrm{~mL}$ with acetone (ca. $1.0 \times$ $\left.10^{-3} \mathrm{M}\right)$. After sequential addition of TMEDA $0.155 \mathrm{~mL}(1.03 \mathrm{mmol})$ and $\mathrm{CuI} 74.5 \mathrm{mg}(0.391 \mathrm{mmol})$, the solution was stirred at $25^{\circ} \mathrm{C}$ for $20 \mathrm{~h}$ in air, concentrated to $c a .20 \mathrm{~mL}$, and filtered through a pad of silica gel with the aid of $\mathrm{CH}_{2} \mathrm{Cl}_{2}$ /acetone (4:1) as eluent. The filtrate was evaporated, and the resulting dark brown oil was subjected to flash silica gel column chromatography $\left(\mathrm{CH}_{2} \mathrm{Cl}_{2} / \mathrm{AcOEt}\right.$, gradient from 20:1 to 5:1) to afford $31.7 \mathrm{mg}(35 \%)$ of $\mathbf{1 h}$ as a yellow powder. ${ }^{1} \mathrm{H}$ NMR $\left(500 \mathrm{MHz}, \mathrm{CDCl}_{3}\right),[\mathrm{ppm}]: 0.88(\mathrm{t}, J=$ $6.7 \mathrm{~Hz}, 12 \mathrm{H}), 1.25-1.32(\mathrm{~m}, 24 \mathrm{H}), 1.49$ (quintet (not well resolved), $J=6.7 \mathrm{~Hz}, 8 \mathrm{H}), 3.17$ (q, $J=6.6 \mathrm{~Hz}$, $8 \mathrm{H}$ ), 4.63, 4.68 (two s, $8 \mathrm{H}$ in total), 4.85, 5.23 (two s, $4 \mathrm{H}$ in total), 6.10, 6.15 (two s, $4 \mathrm{H}$ in total); ${ }^{13} \mathrm{C}\left\{{ }^{1} \mathrm{H}\right\}$ NMR (126 MHz, $\mathrm{CDCl}_{3}$ ) [ppm]: 14.0, 22.5, 26.4, 29.8, 31.4, 41.2, 65.0, 81.4, 81.8, 82.5, 82.6, 118.4, 132.0, 155.3; IR (KBr), $\bar{v}_{\max }\left[\mathrm{cm}^{-1}\right]: 3348$ (br m), 3032 (w), 2954 (m), 2927 (m), 2858 (m), 2204 (w), $2129(\mathrm{w}), 1709$ (s), 1533 (s), 1248 (s), $1228(\mathrm{~m}), 1161(\mathrm{~m}), 1136(\mathrm{~m}) ; \mathrm{UV}$-vis $\left(\mathrm{CHCl}_{3}\right), \lambda_{\max }[\mathrm{nm}](\varepsilon$ $\left.\left[\mathrm{M}^{-1} \cdot \mathrm{cm}^{-1}\right]\right): 312$ (21 800), 334 (30 000), 357 (34 000); MS (MALDI-TOF, reflector mode, 2,5dihydroxybenzoic acid), $m / z$ (\% relative intensity, ion): $947.6\left(100,[\mathrm{M}+\mathrm{Na}]^{+}\right), 963.6\left(86,[\mathrm{M}+\mathrm{K}]^{+}\right)$. 


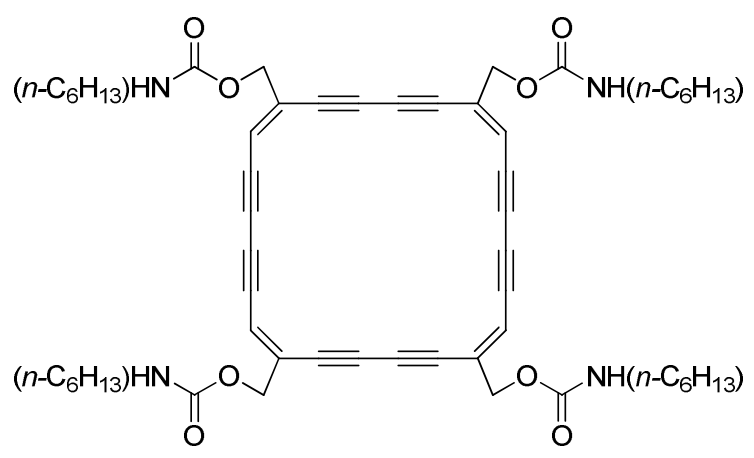

\section{$(1 E, 6 E, 12 E, 18 E)$-Cyclotetracosa-6,12,18,24-tetraen-2,4,8,10,14,16,20,22-octayne-1,6,13,18-}

tetrayltetramethylene tetrakis(phenylcarbamate) (1i). Tetraol 1a $(54.2 \mathrm{mg}, 0.130 \mathrm{mmol})$ was dissolved in $5 \mathrm{ml}$ of THF, and the solution was cooled in an ice bath. Pyridine $(65.0 \mu \mathrm{l}, 0.807 \mathrm{mmol})$ and phenyl isocyanate $(85.0 \mu \mathrm{l}, 0.782 \mathrm{mmol})$ were sequentially added to the solution, and the mixture was stirred at $0-5{ }^{\circ} \mathrm{C}$ for $10 \mathrm{~min}$ then at $25^{\circ} \mathrm{C}$ for $10 \mathrm{~h}$. At this point, TLC monitoring indicated that there was still the starting material $1 \mathrm{a}$ remaining in the mixture $\left(R_{f}=0.30\right.$ with $\left.\mathrm{THF} / \mathrm{CH}_{2} \mathrm{Cl}_{2}, 1: 1\right)$. Additional phenyl isocyanate $(115 \mu \mathrm{l}, 1.06 \mathrm{mmol}$ in total $)$ and pyridine $(130 \mu \mathrm{l}, 1.61 \mathrm{mmol}$ in total) were added portion-wise over 3 days, until TLC showed a single main spot $\left(R_{f}=0.60\right.$ with $\left.\mathrm{CH}_{2} \mathrm{Cl}_{2} / \mathrm{AcOEt}, 5: 1\right)$. The reaction mixture was poured to a separatory funnel containing $20 \mathrm{~mL}$ of AcOEt, $10 \mathrm{~mL}$ of sat. $\mathrm{NH}_{4} \mathrm{Cl}$, and $10 \mathrm{~mL}$ of water. The organic phase was isolated, washed with water $(2 \times 10 \mathrm{~mL})$, dried over $\mathrm{MgSO}_{4}$, filtered, and evaporated to give a yellow solid. The solid was dissolved in $20 \mathrm{~mL}$ of acetone and concentrated to $c a .5 \mathrm{~mL}$ to form a white precipitate, which was removed by filtration. The filtrate was evaporated to dryness, and the resulting solid was dissolved in $2 \mathrm{~mL}$ of THF. Upon addition of $\mathrm{Et}_{2} \mathrm{O}$, white solid precipitated out, which was again removed by filtration. The filtrate was evaporated to dryness, and the resulting solid was further purified through precipitation from a THF solution by adding pentanes (once) then from an acetone solution by adding pentanes (five times). After drying in vacuo, $45.7 \mathrm{mg}(39 \%)$ of $1 \mathbf{i}$ was obtained as a yellow powder. ${ }^{1} \mathrm{H}$ NMR $\left(500 \mathrm{MHz}\right.$, acetone- $\left.d_{6}\right),[\mathrm{ppm}]: 4.82(\mathrm{~s}$, $8 \mathrm{H}), 6.53(\mathrm{~s}, 4 \mathrm{H}), 7.04(\mathrm{t}, J=7.4 \mathrm{~Hz}, 4 \mathrm{H}), 7.30(\mathrm{t}, J=7.9 \mathrm{~Hz}, 8 \mathrm{H}), 7.55$ (d, $J=7.9 \mathrm{~Hz}, 4 \mathrm{H}), 8.91$ (br s, $\left.2.5 \mathrm{H}^{a}\right) ;{ }^{13} \mathrm{C}\left\{{ }^{1} \mathrm{H}\right\}$ NMR (126 MHz, acetone- $\left.d_{6}\right),[\mathrm{ppm}]: 65.6,82.3,82.4,82.5,82.9,119.4,112.0,123.9$, 
129.8, 133.9, 139.9, 153.5; IR (KBr), $\bar{v}_{\max }\left[\mathrm{cm}^{-1}\right]: 3398(\mathrm{~m}), 3315(\mathrm{~m}), 3199(\mathrm{w}), 3136(\mathrm{w}), 3057(\mathrm{~m})$, 3037 (m), 2951 (w), 2193 (w), 2173 (w), 2125 (w), 1714 (s), 1601 (s), 1529 (s), 1500 (s), 1444 (s), 1408 (m), 1313 (s), 1215 (s), 1086 (s); UV-vis $\left(\mathrm{CHCl}_{3}\right), \lambda_{\max }[\mathrm{nm}]\left(\varepsilon\left[\mathrm{M}^{-1} \cdot \mathrm{cm}^{-1}\right]\right): 334(42000), 344$ (38 500), 357 (48 000); MS (MALDI-TOF, reflector mode, 2,5-dihydroxybenzoic acid), $m / z$ (\% relative intensity, ion): $915.3\left(100,[\mathrm{M}+\mathrm{Na}]^{+}\right), 931.2\left(15,[\mathrm{M}+\mathrm{K}]^{+}\right)$.

${ }^{a}$ Smaller than the expected value of four probably because of the H-D exchange with acetone- $d_{6}$.

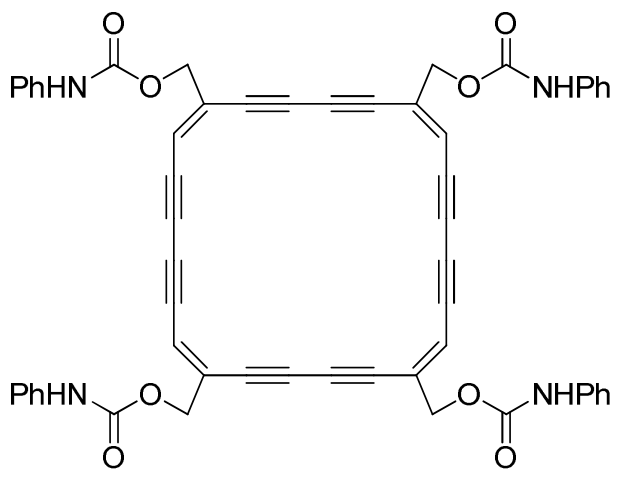

(2E,7E)-2,7-Bis(3-(triisopropylsilyl)prop-2-ynylidene)octa-3,5-diyne-1,8-diyl bis(4-methoxyphenylcarbamate) (4c). Diol 3 (101 mg, $0.193 \mathrm{mmol})$ and DMAP (2.29 $\mathrm{mg}, 18.7 \mu \mathrm{mol})$ were dissolved in $3 \mathrm{ml}$ of THF, to which $i$ - $\operatorname{Pr}_{2} \mathrm{NEt}(100 \mu \mathrm{l}, 0.574 \mathrm{mmol})$ and 4-methoxyphenyl isocyanate $(75.0 \mu \mathrm{l}, 0.582$ mmol) were sequentially added. After stirring at $40{ }^{\circ} \mathrm{C}$ for $7.5 \mathrm{~h}$, the solution was quenched by adding 0.5 $\mathrm{mL}$ of $\mathrm{MeOH}$ and stirred at $25{ }^{\circ} \mathrm{C}$ for additional $30 \mathrm{~min}$. After evaporated to dryness, the mixture was subjected to flash silica gel column chromatography $\left(\mathrm{CH}_{2} \mathrm{Cl}_{2} / \mathrm{AcOEt}, 50: 1\right)$ to afford $157 \mathrm{mg}(99 \%)$ of $\mathbf{4 c}$ as a light yellow oil. ${ }^{1} \mathrm{H}$ NMR (500 MHz, $\left.\mathrm{CDCl}_{3}\right)$, [ppm]: 1.10 (s, 42H), 3.77 (s, 6H), $4.70(\mathrm{~s}, 4 \mathrm{H}), 6.14$ (s, 4H), 6.84-6.87 (overlapping s and d, $6 \mathrm{H}$ in total), 7.28 (s, 4H); ${ }^{13} \mathrm{C}\left\{{ }^{1} \mathrm{H}\right\}$ NMR (126 MHz, $\mathrm{CDCl}_{3}$ ), [ppm]: $11.1,18.5,55.4,65.3,80.8,81.4,102.4,103.0,120.7,120.8,128.8,130.5,152.9,156.0 ; \mathrm{IR}(\mathrm{KBr}), \bar{v}_{\max }$

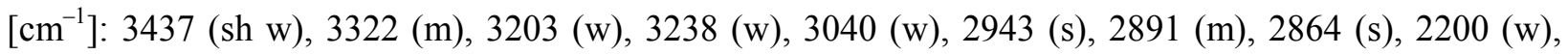
2134 (w), 1712 (s), 1602 (m), 1515 (s), 1246 (sh m), 1215 (s), 1177 (m), 1059 (m), 1035 (m); UV-vis $\left(\mathrm{CHCl}_{3}\right), \lambda_{\max }[\mathrm{nm}]\left(\varepsilon\left[\mathrm{M}^{-1} \cdot \mathrm{cm}^{-1}\right]\right): 241$ (36 000), 299 (15 100), 320 (14 300), 343 (15 400), 369 (14 100); 
MS (MALDI-TOF, reflector mode, 2,5-dihydroxybenzoic acid), $\mathrm{m} / \mathrm{z}$ (\% relative intensity, ion): 843.6 $\left(100,[\mathrm{M}+\mathrm{Na}]^{+}\right), 859.6\left(80,[\mathrm{M}+\mathrm{K}]^{+}\right)$.

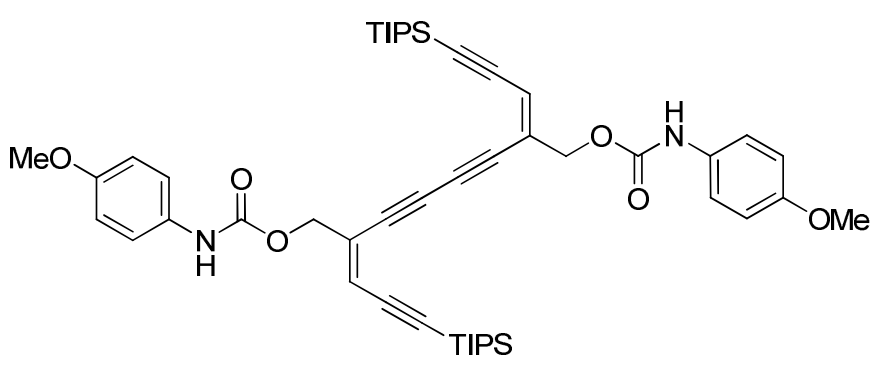

\section{$(1 E, 6 E, 12 E, 18 E)$-Cyclotetracosa-6,12,18,24-tetraen-2,4,8,10,14,16,20,22-octayne-1,6,13,18-}

tetrayltetra-methylene tetrakis(4-methoxyphenylcarbamate) (1j). The protected precursor 4c (129 $\mathrm{mg}$, $0.157 \mathrm{mmol})$ was dissolved in $5 \mathrm{~mL}$ of THF. The solution was cooled in an ice bath, to which water $(0.05$ $\mathrm{mL}$ ), AcOH (1.0 M in THF, $0.35 \mathrm{~mL}, 0.35 \mathrm{mmol})$, and TBAF (1.0 M in THF, $0.35 \mathrm{~mL}, 0.35 \mathrm{mmol})$ were sequentially added. After stirring at $0-5{ }^{\circ} \mathrm{C}$ for $30 \mathrm{~min}$, the solution was poured to a separatory funnel containing $20 \mathrm{~mL}$ of $\mathrm{Et}_{2} \mathrm{O}$ and $10 \mathrm{~mL}$ of $10 \% \mathrm{NH}_{4} \mathrm{Cl}$. The organic phase was isolated, washed with water $(3 \times 10 \mathrm{~mL})$ then brine $(10 \mathrm{~mL})$, dried over $\mathrm{MgSO}_{4}$, filtered, and evaporated to about $30 \mathrm{~mL}$. The solution was diluted with $30 \mathrm{~mL}$ of acetone, concentrated to about $5 \mathrm{~mL}$, and diluted again to $155 \mathrm{~mL}$ with acetone (ca. $\left.1.0 \times 10^{-3} \mathrm{M}\right)$. After addition of TMEDA $(0.120 \mathrm{~mL}, 0.795 \mathrm{mmol})$ and $\mathrm{CuI}(60.5 \mathrm{mg}, 0.318 \mathrm{mmol})$, the solution was stirred at $25{ }^{\circ} \mathrm{C}$ for $24 \mathrm{~h}$, concentrated to about $5 \mathrm{~mL}$, and filtered through a pad of silica gel with the aid of $\mathrm{CH}_{2} \mathrm{Cl}_{2}$ /acetone (4:1) as eluent. After evaporated to dryness, the mixture was subjected to flash silica gel column chromatography $\left(\mathrm{CH}_{2} \mathrm{Cl}_{2} / \mathrm{THF}\right.$, gradient from 50:1 to 5:1) to afford $10.2 \mathrm{mg}$ $(13 \%)$ of $\mathbf{1 j}$ as a yellow powder. ${ }^{1} \mathrm{H}$ NMR (500 MHz, DMSO- $\left.d_{6}\right),[\mathrm{ppm}]: 3.70(\mathrm{~s}, 6 \mathrm{H}), 4.76(\mathrm{~s}, 4 \mathrm{H}), 6.69$ $(\mathrm{s}, 2 \mathrm{H}), 6.86(\mathrm{~d}, J=8.9 \mathrm{~Hz}, 2 \mathrm{H}), 7.34(\mathrm{~d}, J=8.4 \mathrm{~Hz}, 2 \mathrm{H}), 9.66(\mathrm{~s}, 2 \mathrm{H}) ;{ }^{13} \mathrm{C}\left\{{ }^{1} \mathrm{H}\right\} \mathrm{NMR}(126 \mathrm{MHz}$, DMSO- $\left.d_{6}\right),[\mathrm{ppm}]: 55.0,64.2,80.9,81.1,82.0,82.3,113.9,119.6,119.8,131.5,132.8,152.6,154.9$; IR (KBr), $\bar{v}_{\max }\left[\mathrm{cm}^{-1}\right]: 3303(\mathrm{~m}), 3134(\mathrm{w}), 3033(\mathrm{w}), 3001(\mathrm{w}), 2951(\mathrm{w}), 2934(\mathrm{w}), 2908(\mathrm{w}), 2834(\mathrm{w})$, $2192(\mathrm{w}), 2170(\mathrm{w}), 2124(\mathrm{w}), 1709$ (s), 1601 (m), 1515 (s), 1214 (s), 1176 (m), 1082 (m), 1031 (m); UV-vis $\left(\mathrm{CHCl}_{3}\right), \lambda_{\max }[\mathrm{nm}]\left(\varepsilon\left[\mathrm{M}^{-1} \cdot \mathrm{cm}^{-1}\right]\right): 336$ (29 000), 357 (33 200); MS (MALDI-TOF, reflector 
mode, 2,5-dihydroxybenzoic acid), $m / z$ (\% relative intensity, ion): $1035.5\left(100,[\mathrm{M}+\mathrm{Na}]^{+}\right), 1051.5(95$, $\left.[\mathrm{M}+\mathrm{K}]^{+}\right)$.

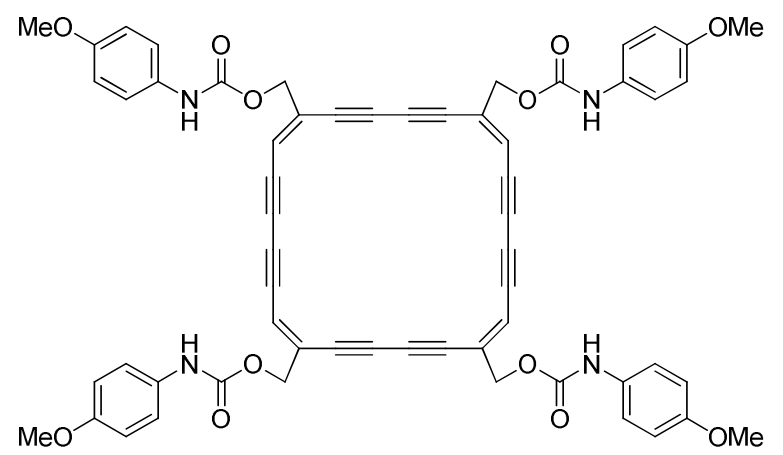


2. NMR Spectra
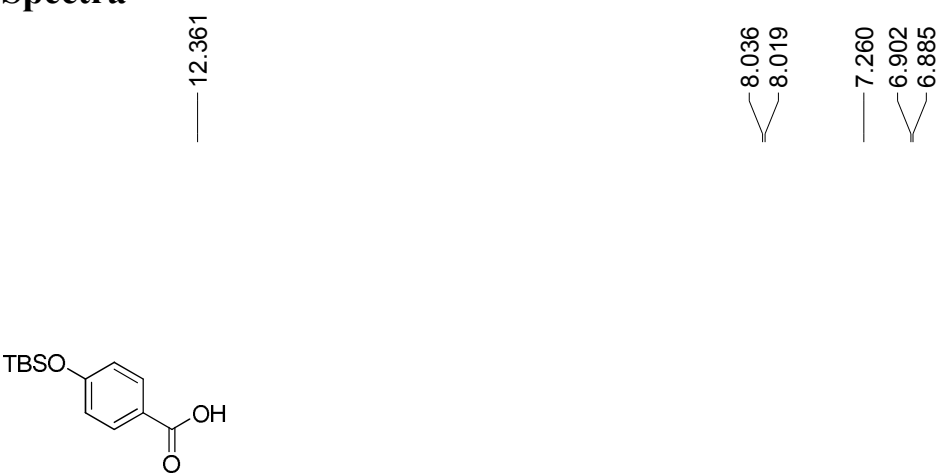

$\stackrel{\bar{్}}{\stackrel{్}{\mathrm{~N}}}$

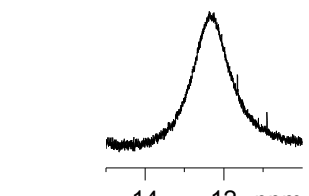

$14 \quad 12 \mathrm{ppm}$

$\frac{\infty}{0}$

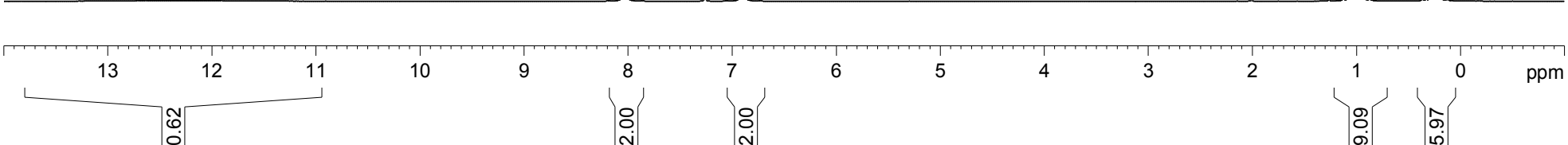

Figure S1. ${ }^{1} \mathrm{H}$ NMR spectrum of 4-( $t$-butyldimethylsilyloxy)benzoic acid $\left(\mathrm{CDCl}_{3}, 500 \mathrm{MHz}\right)$. 
TBSO<smiles>O=C(O)c1ccccc1</smiles>

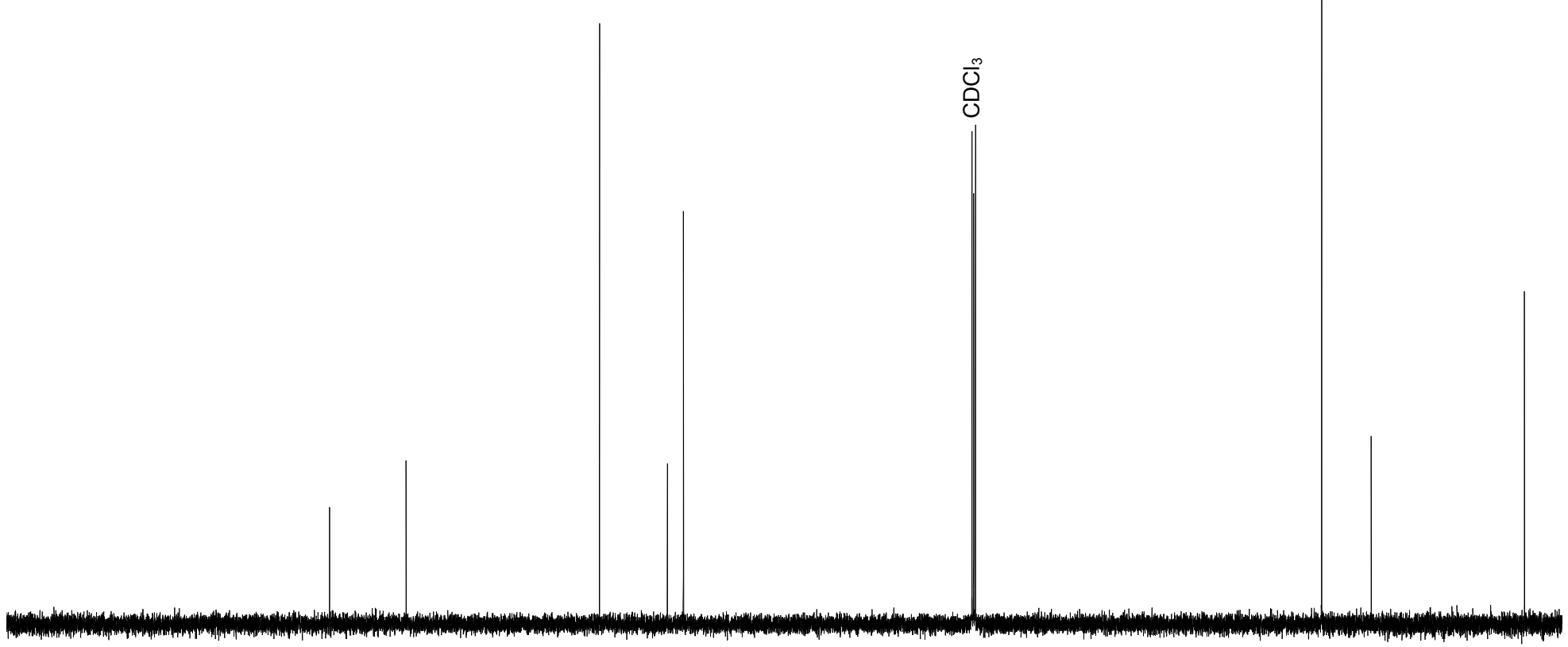

$210 \quad 200 \quad 190$

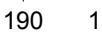




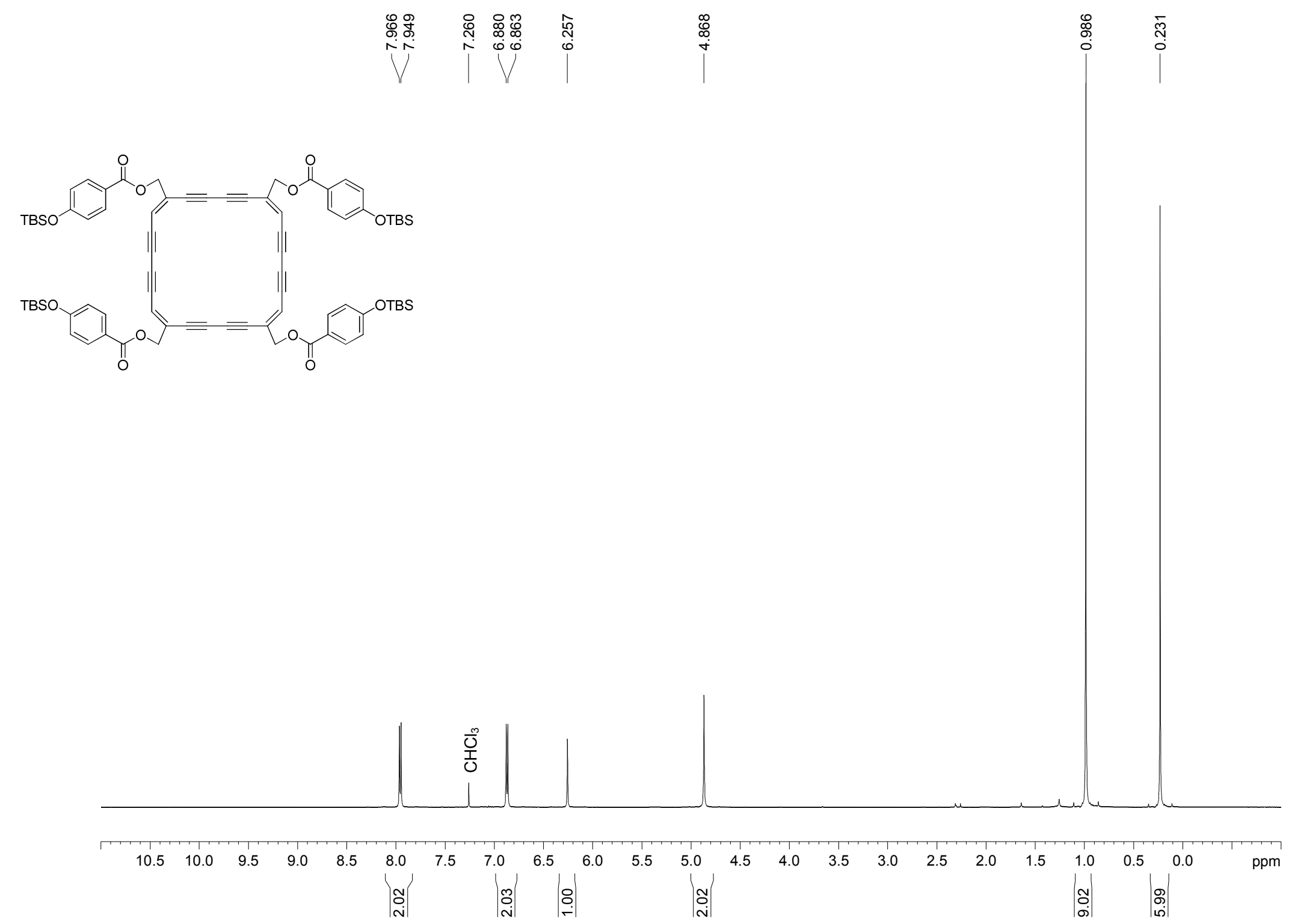

Figure S3. ${ }^{1} \mathrm{H}$ NMR spectrum of the precursor of $\mathbf{1 b}\left(\mathrm{CDCl}_{3}, 500 \mathrm{MHz}\right)$. 

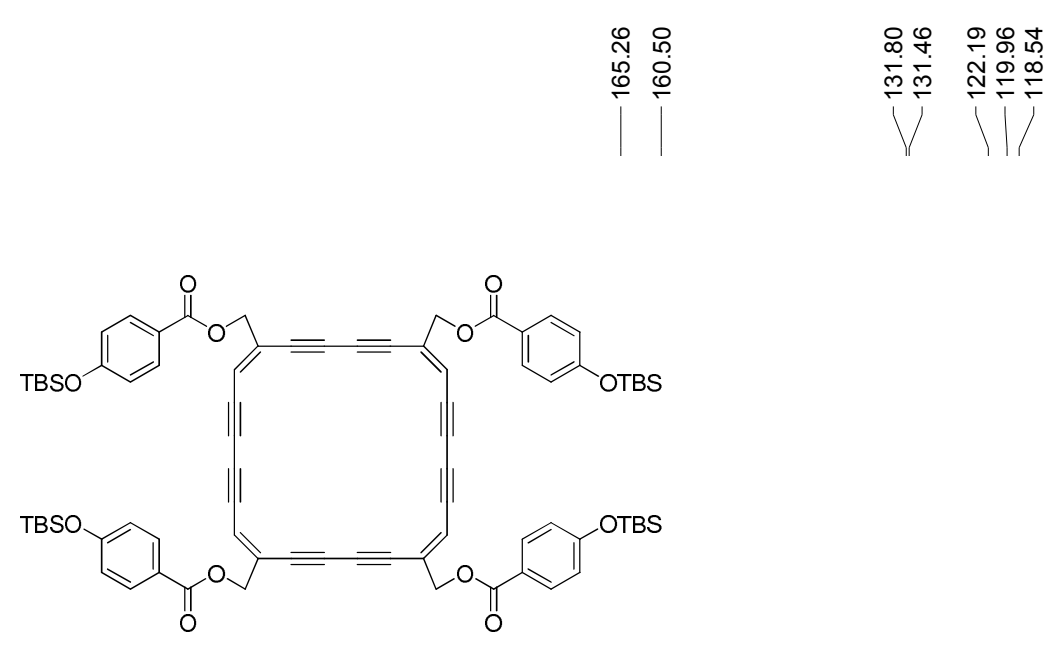

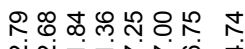

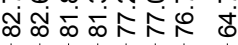

点

ษ

$\left.\right|_{0} ^{1}$

TBS
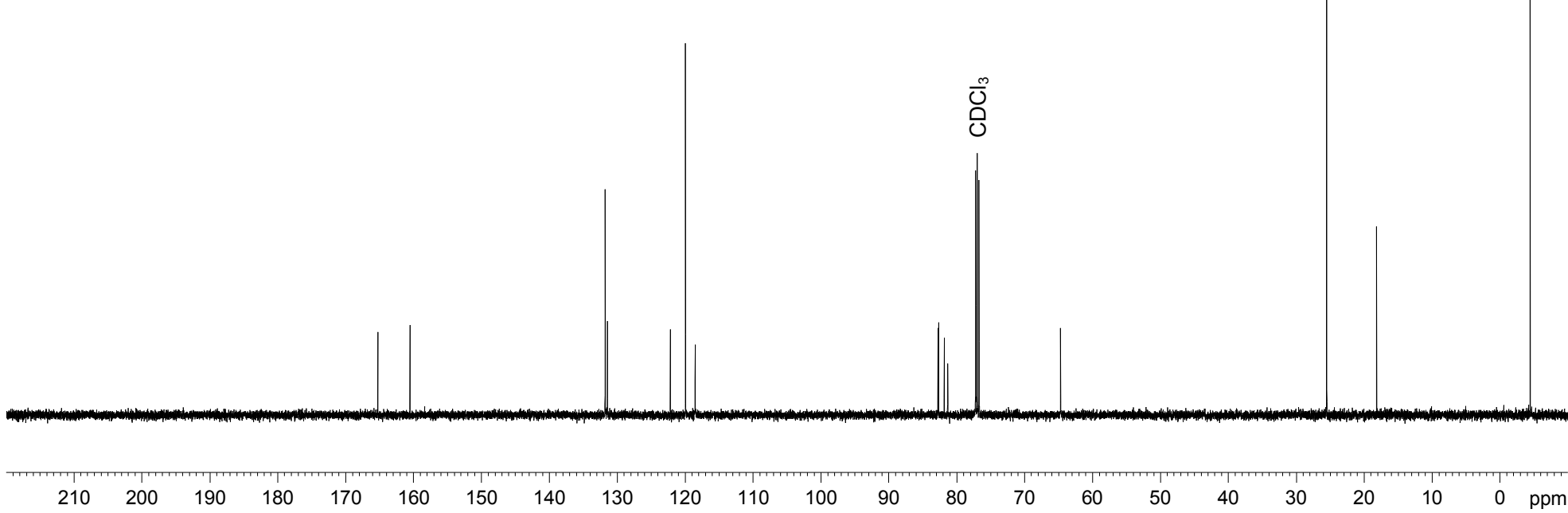

Figure S4. ${ }^{13} \mathrm{C}$ NMR spectrum of the precursor of $\mathbf{1 b}\left(\mathrm{CDCl}_{3}, 126 \mathrm{MHz}\right)$. 


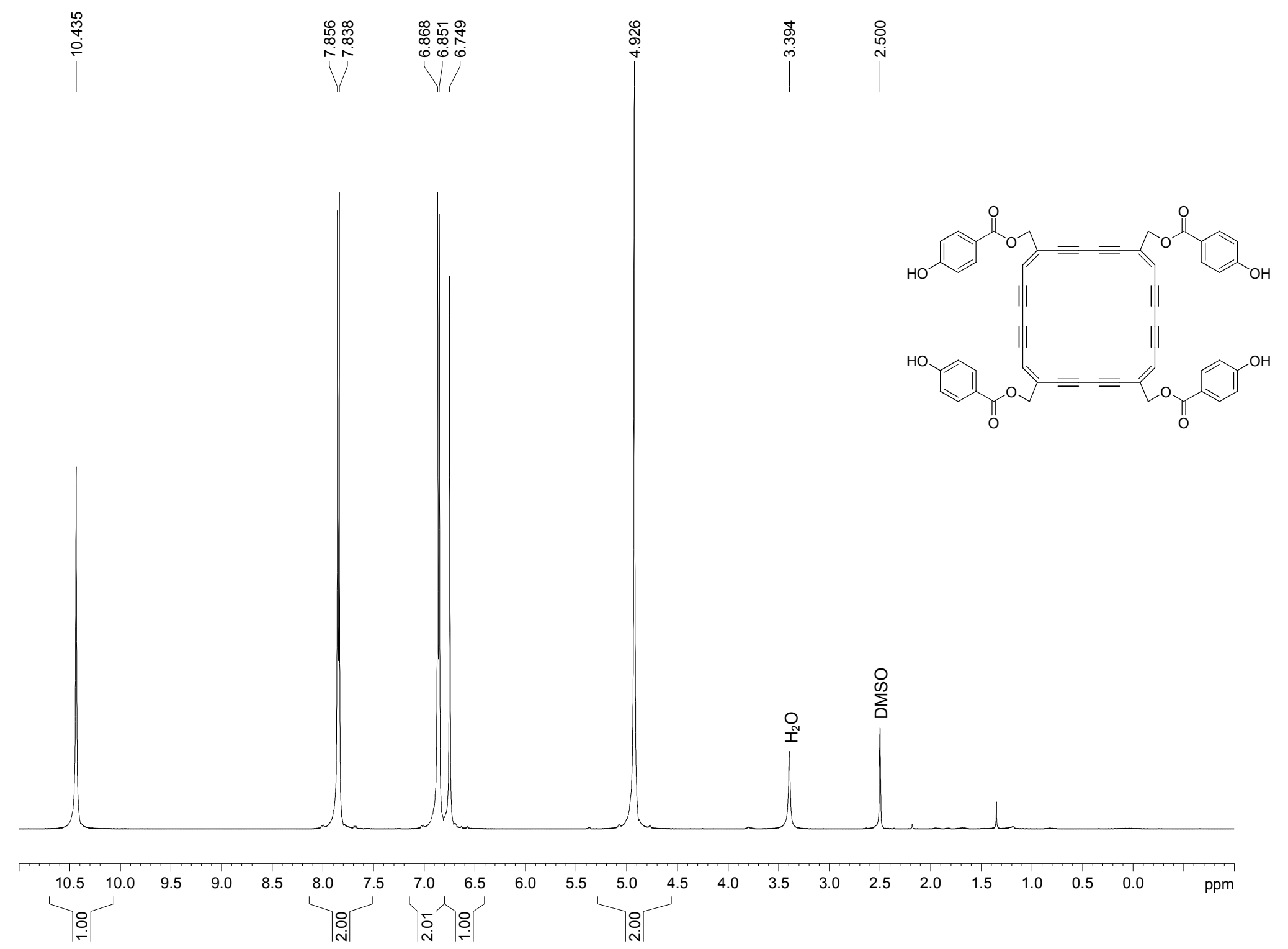

Figure S5. ${ }^{1} \mathrm{H}$ NMR spectrum of $\mathbf{1 b}\left(\mathrm{DMSO}-d_{6}, 500 \mathrm{MHz}\right)$. 


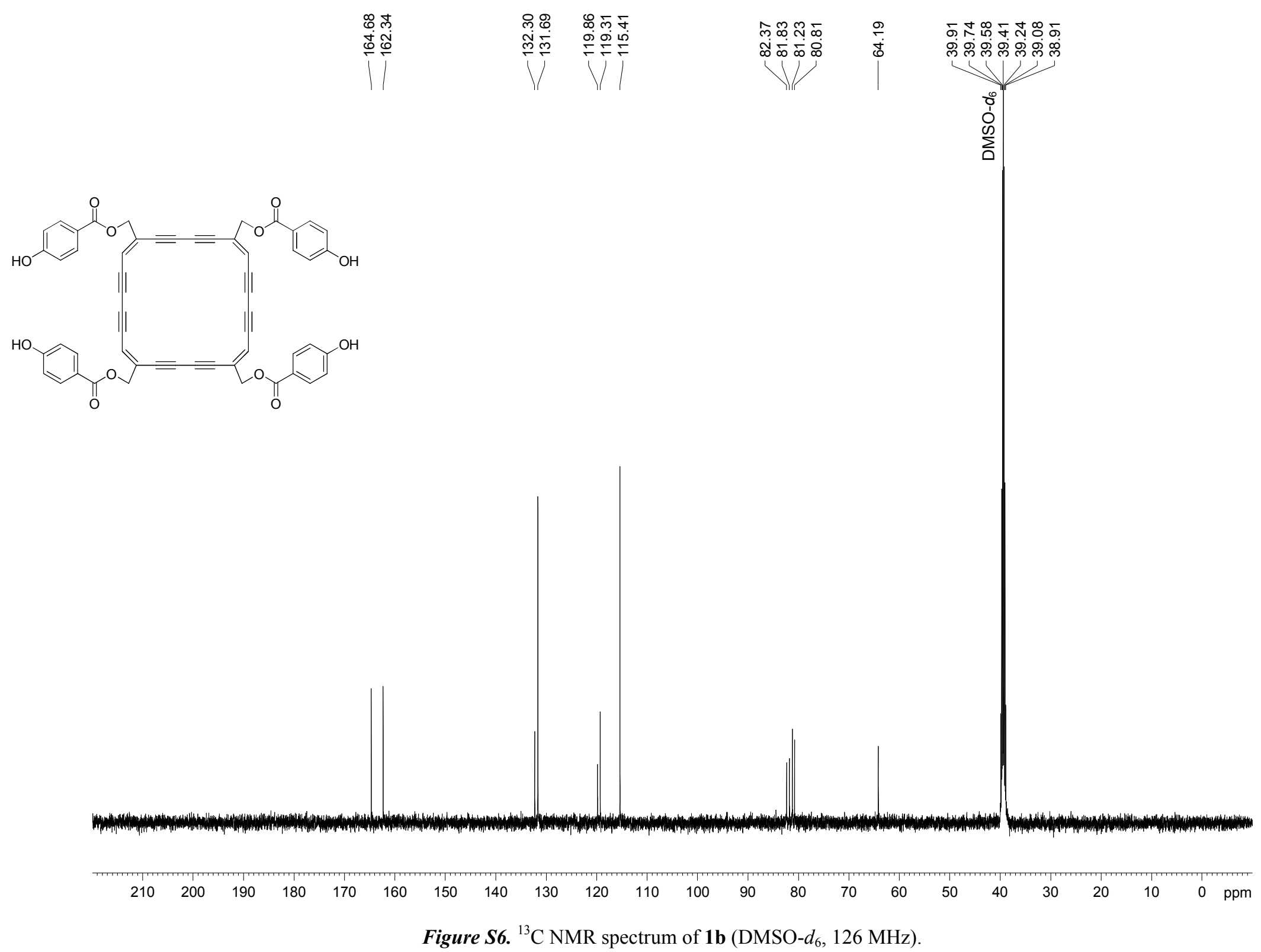




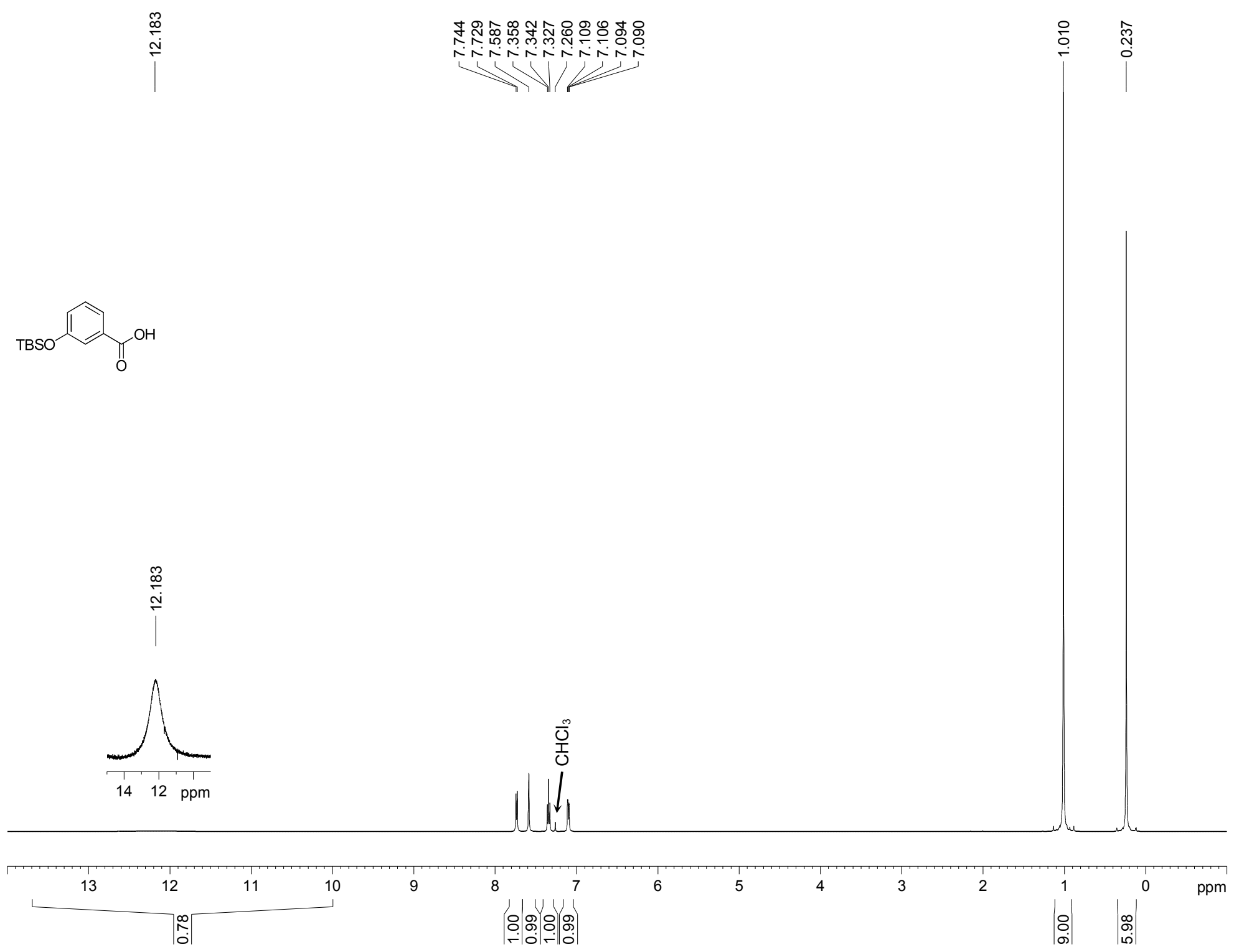

Figure S7. ${ }^{1} \mathrm{H}$ NMR spectrum of 3-(t-butyldimethylsilyloxy)benzoic acid $\left(\mathrm{CDCl}_{3}, 500 \mathrm{MHz}\right)$. 


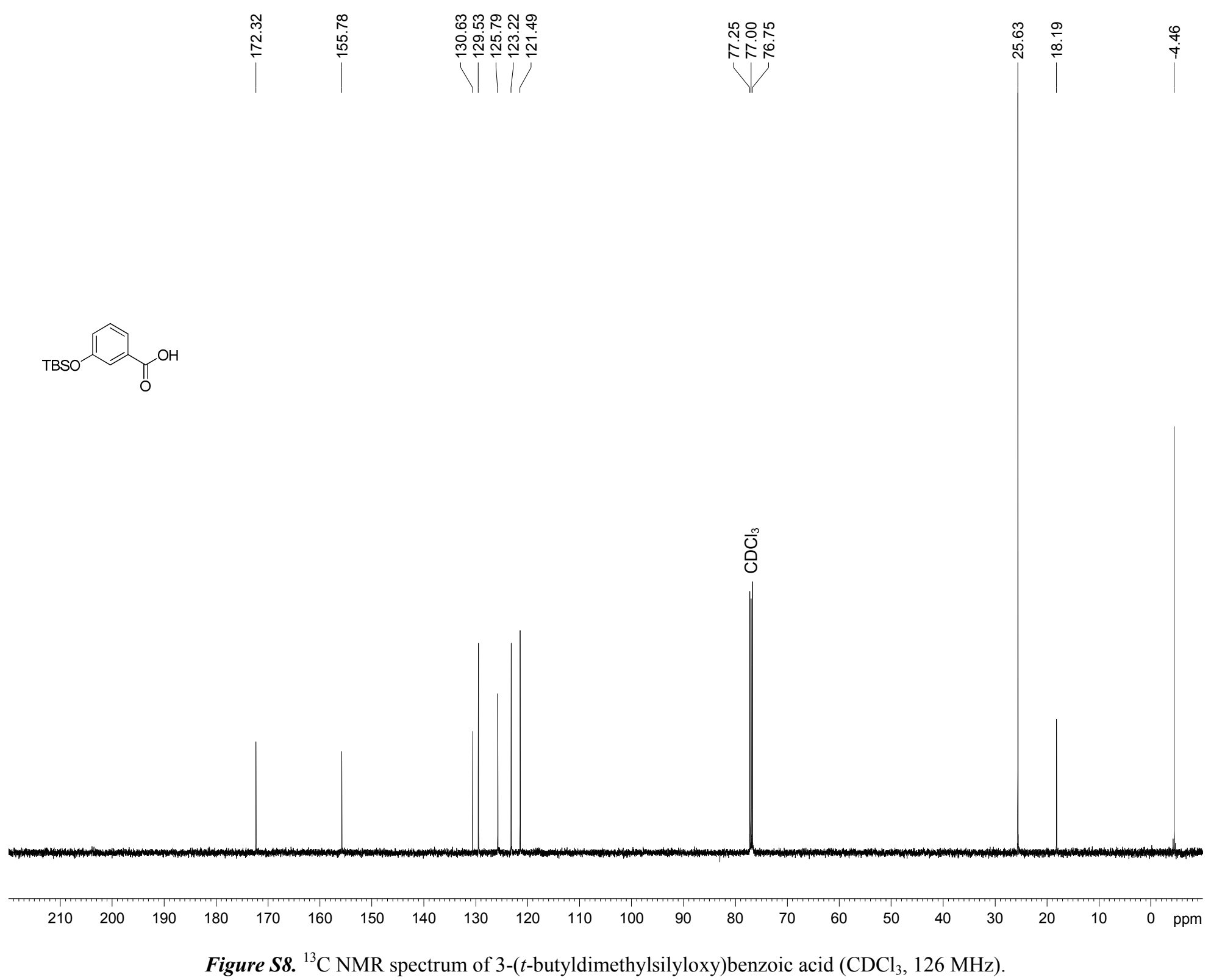




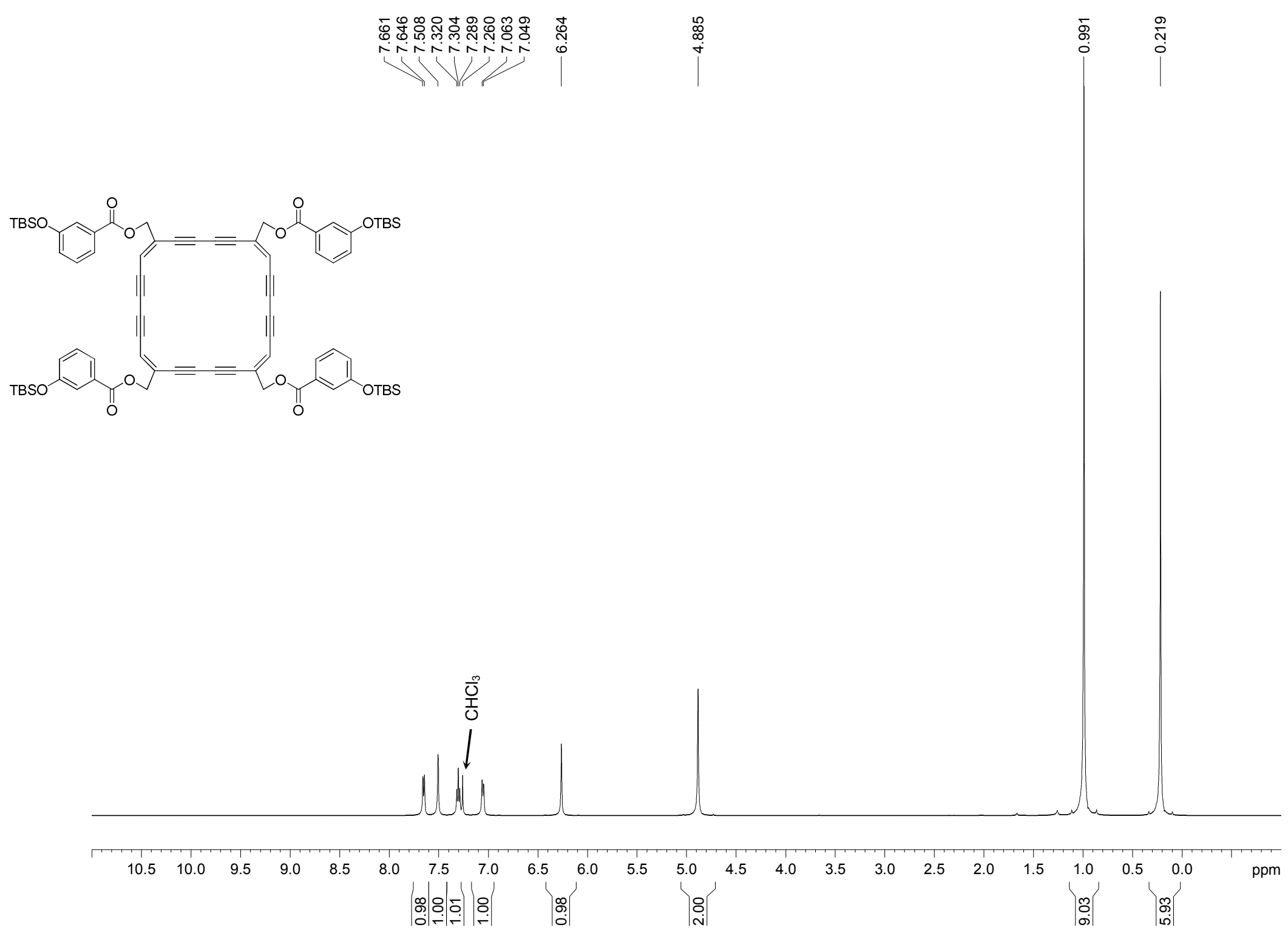

Figure S9. ${ }^{1} \mathrm{H} \mathrm{NMR}$ spectrum of the precursor of $\mathbf{1 c}\left(\mathrm{CDCl}_{3}, 500 \mathrm{MHz}\right)$. 


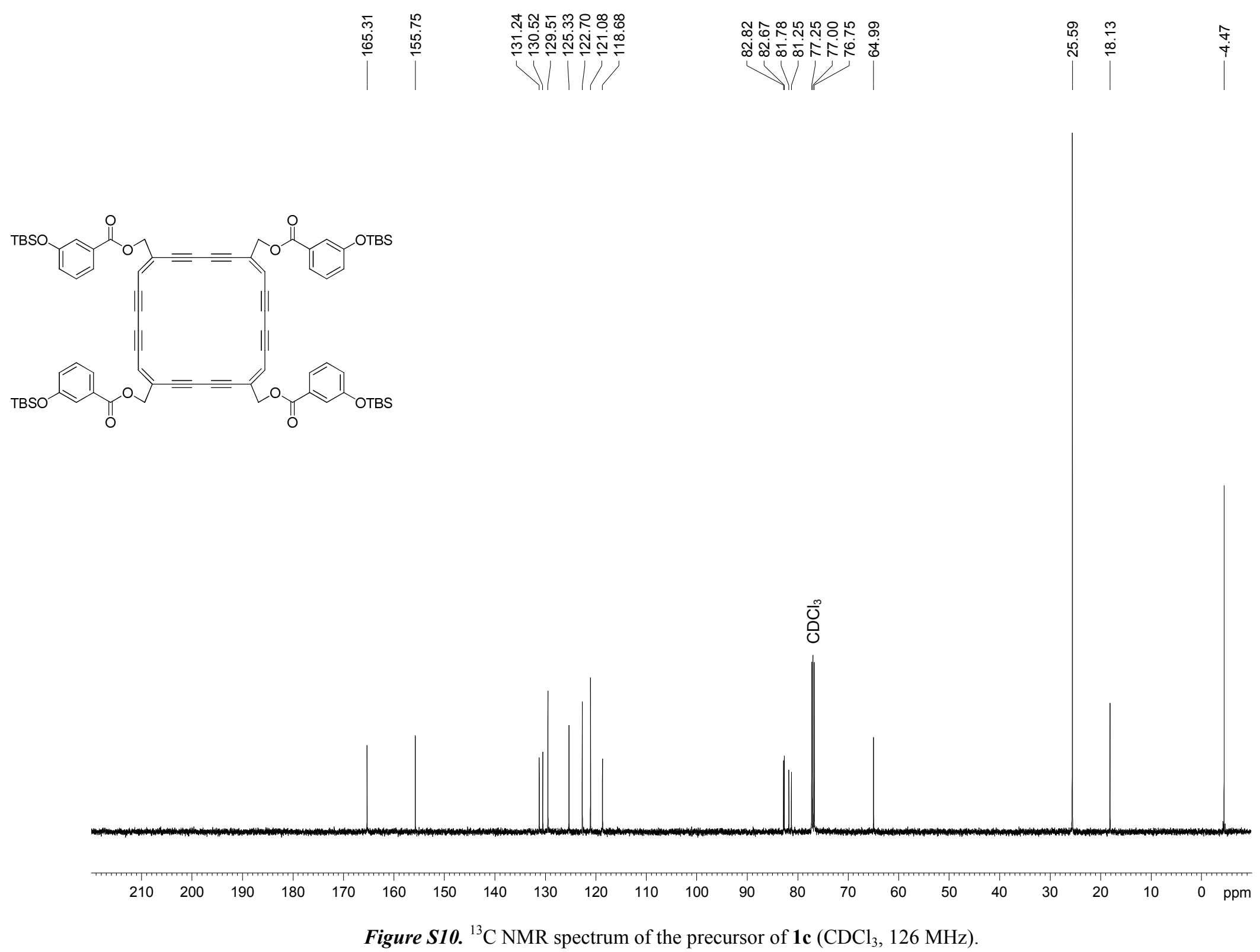




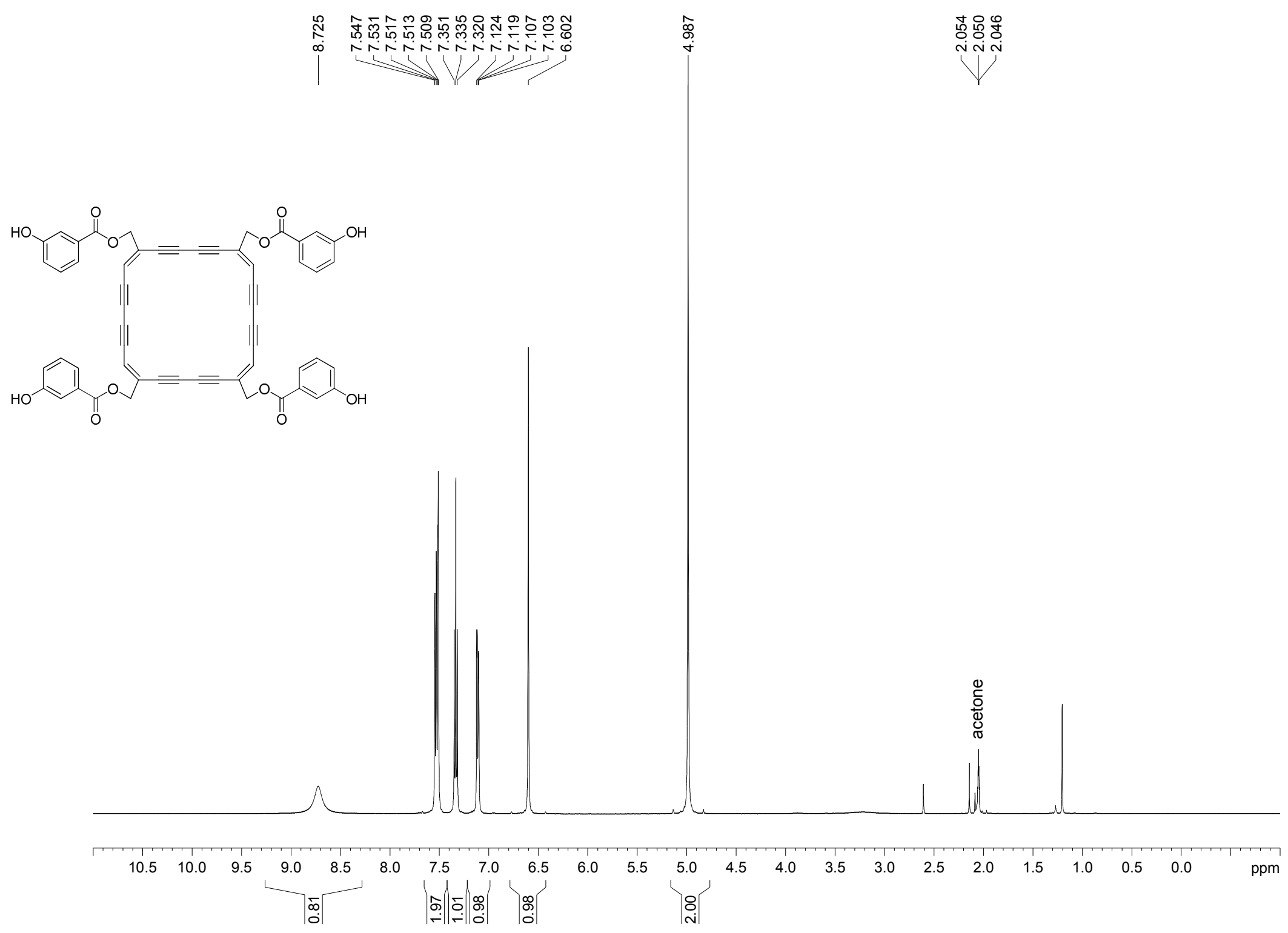

Figure S11. ${ }^{1} \mathrm{H}$ NMR spectrum of 1c (acetone- $d_{6}, 500 \mathrm{MHz}$ ). 


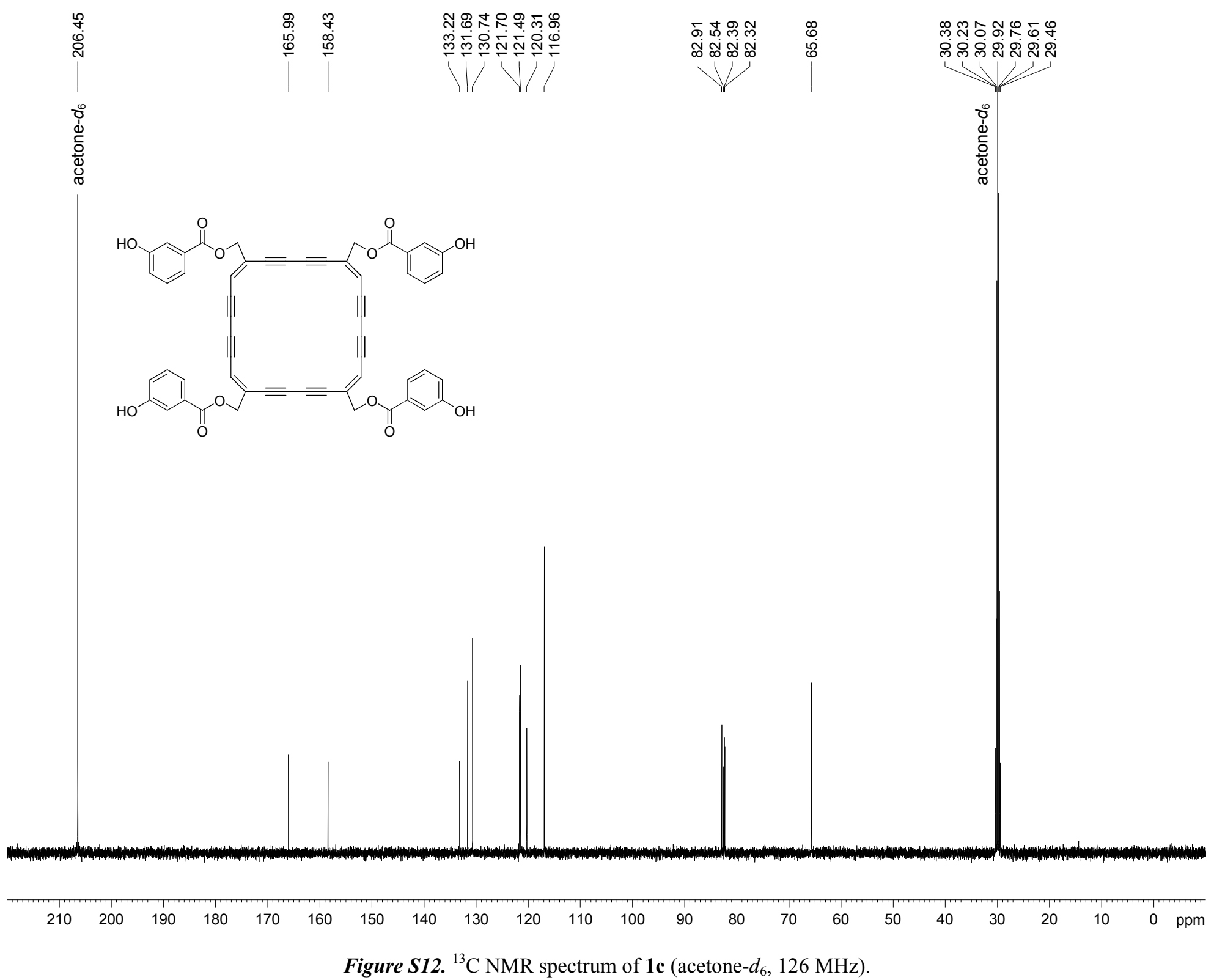




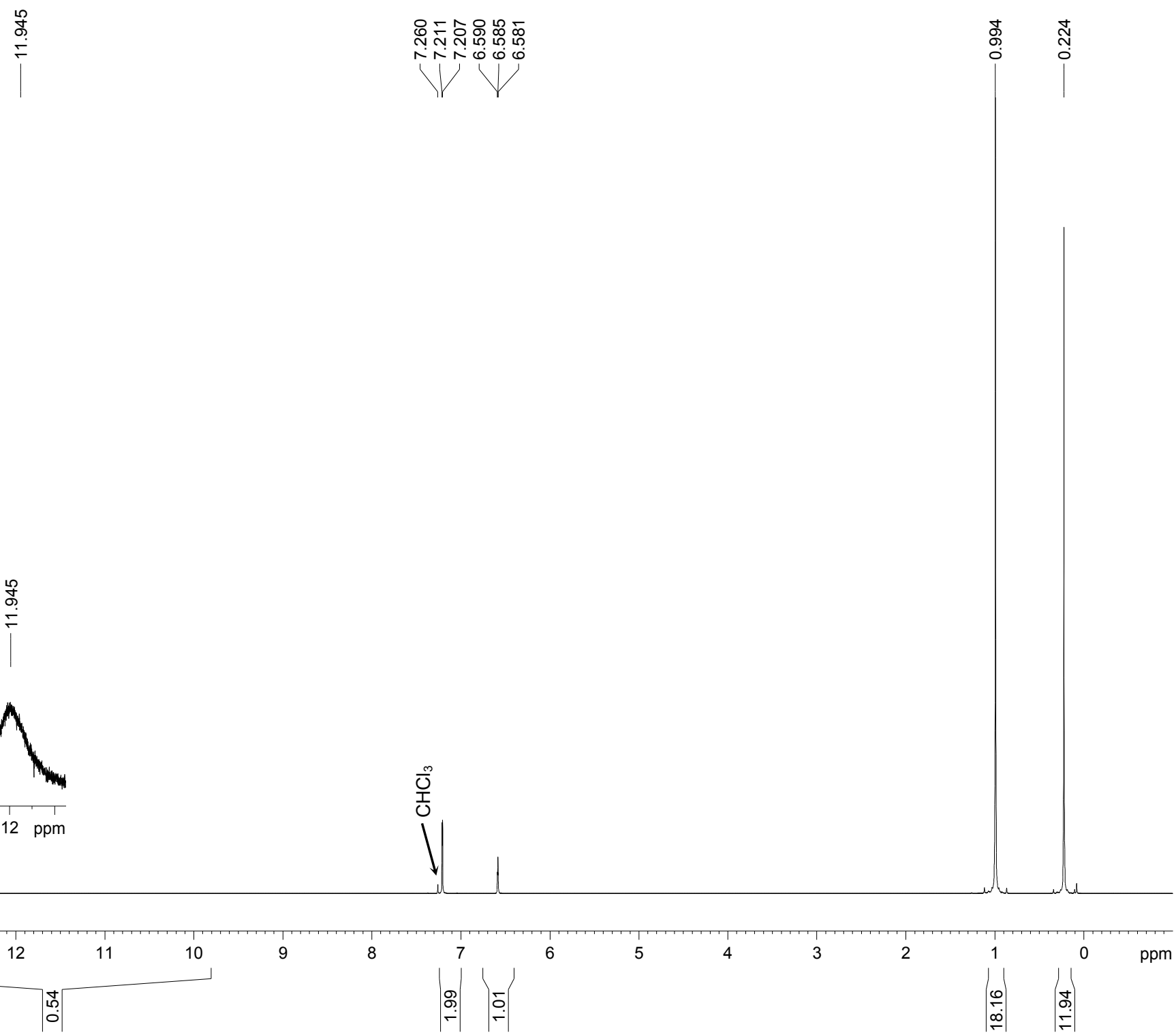

Figure S13. ${ }^{1} \mathrm{H}$ NMR spectrum of 3,5-bis(t-butyldimethylsilyloxy)benzoic acid $\left(\mathrm{CDCl}_{3}, 500 \mathrm{MHz}\right)$. 


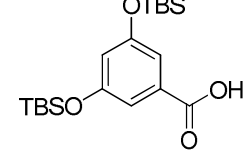

Figure S14. ${ }^{13} \mathrm{C}$ NMR spectrum of 3,5-bis(t-butyldimethylsilyloxy)benzoic acid $\left(\mathrm{CDCl}_{3}, 126 \mathrm{MHz}\right)$. 


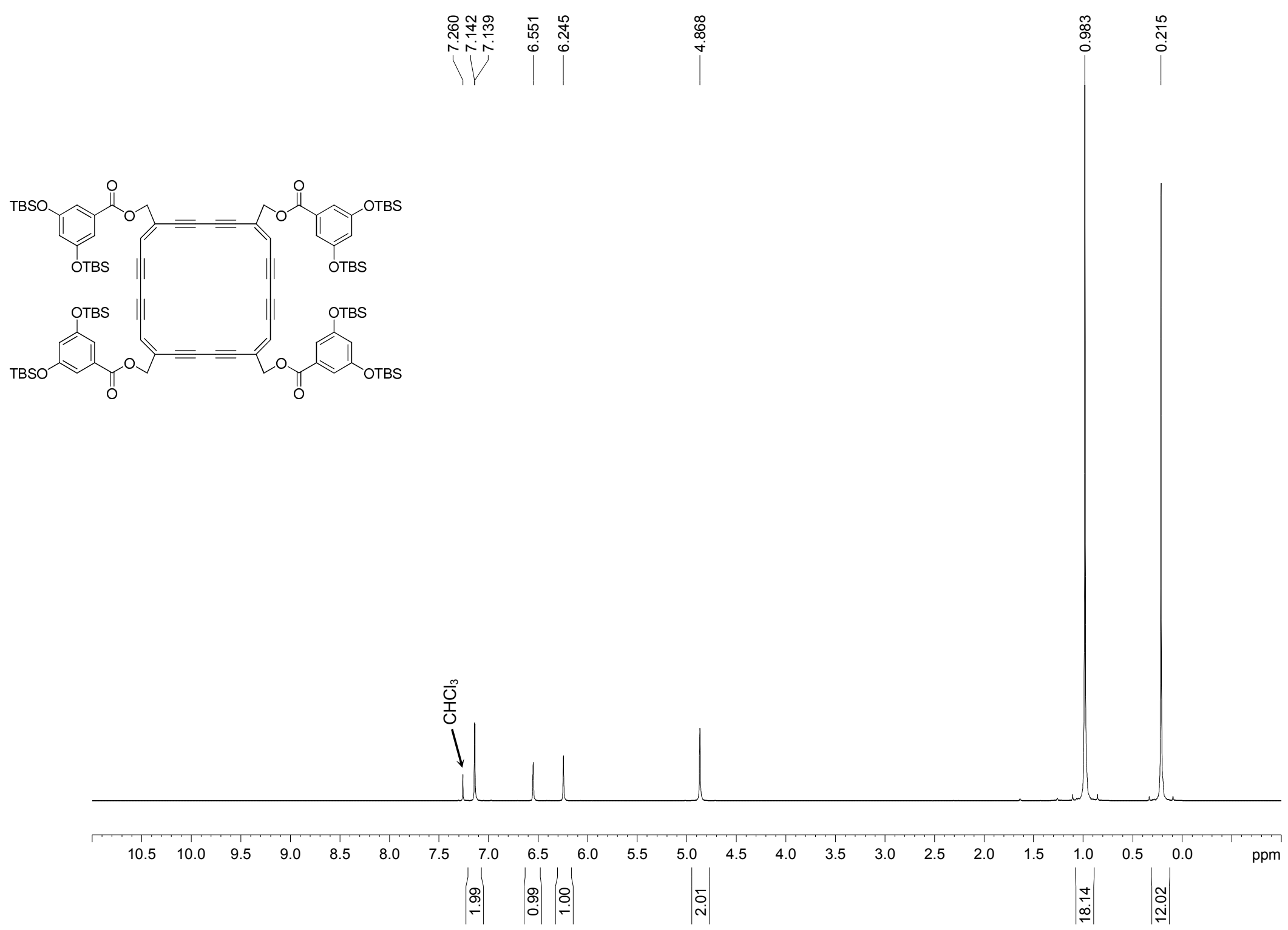

Figure S15. ${ }^{1} \mathrm{H}$ NMR spectrum of the precursor of $1 \mathbf{d}\left(\mathrm{CDCl}_{3}, 500 \mathrm{MHz}\right)$. 


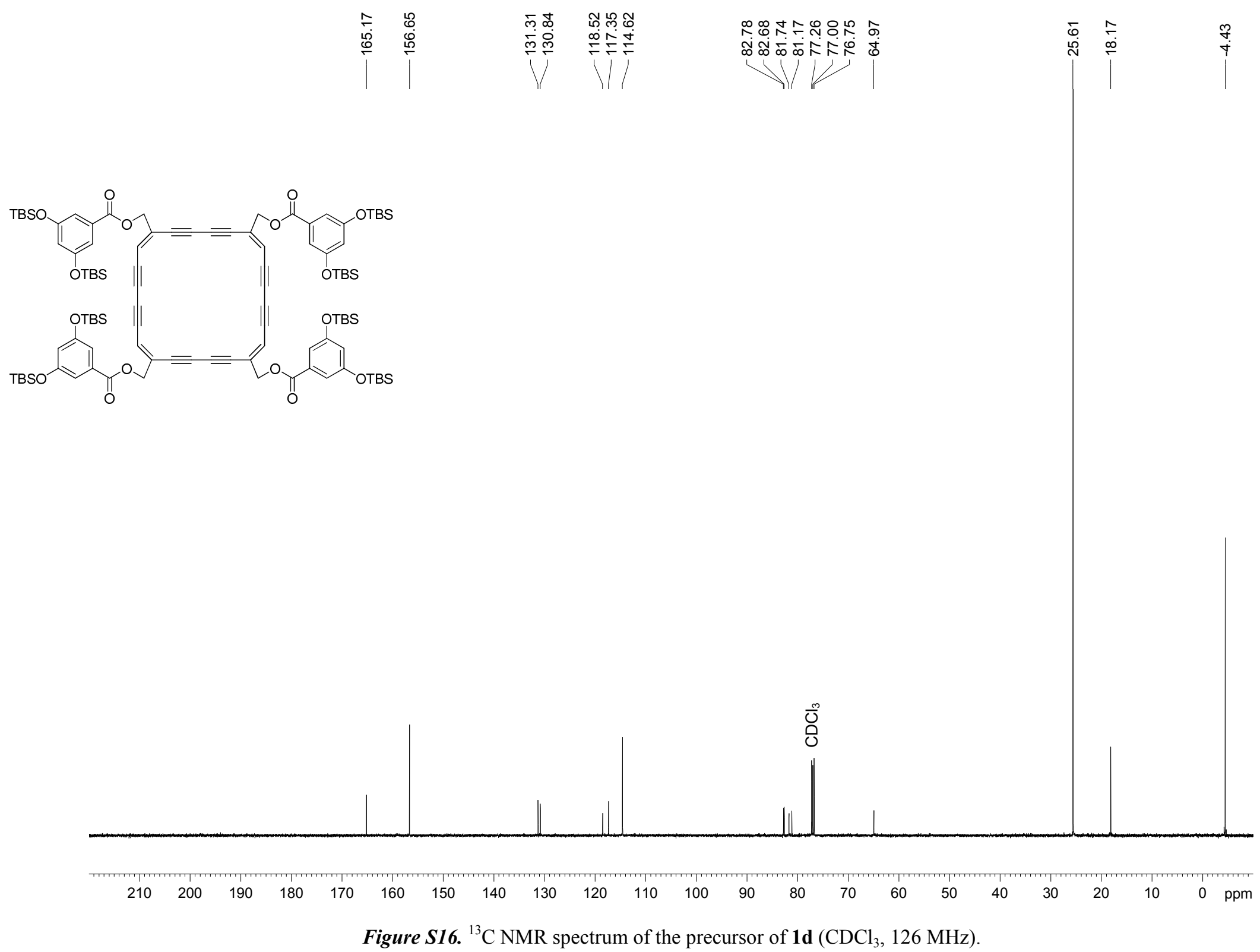




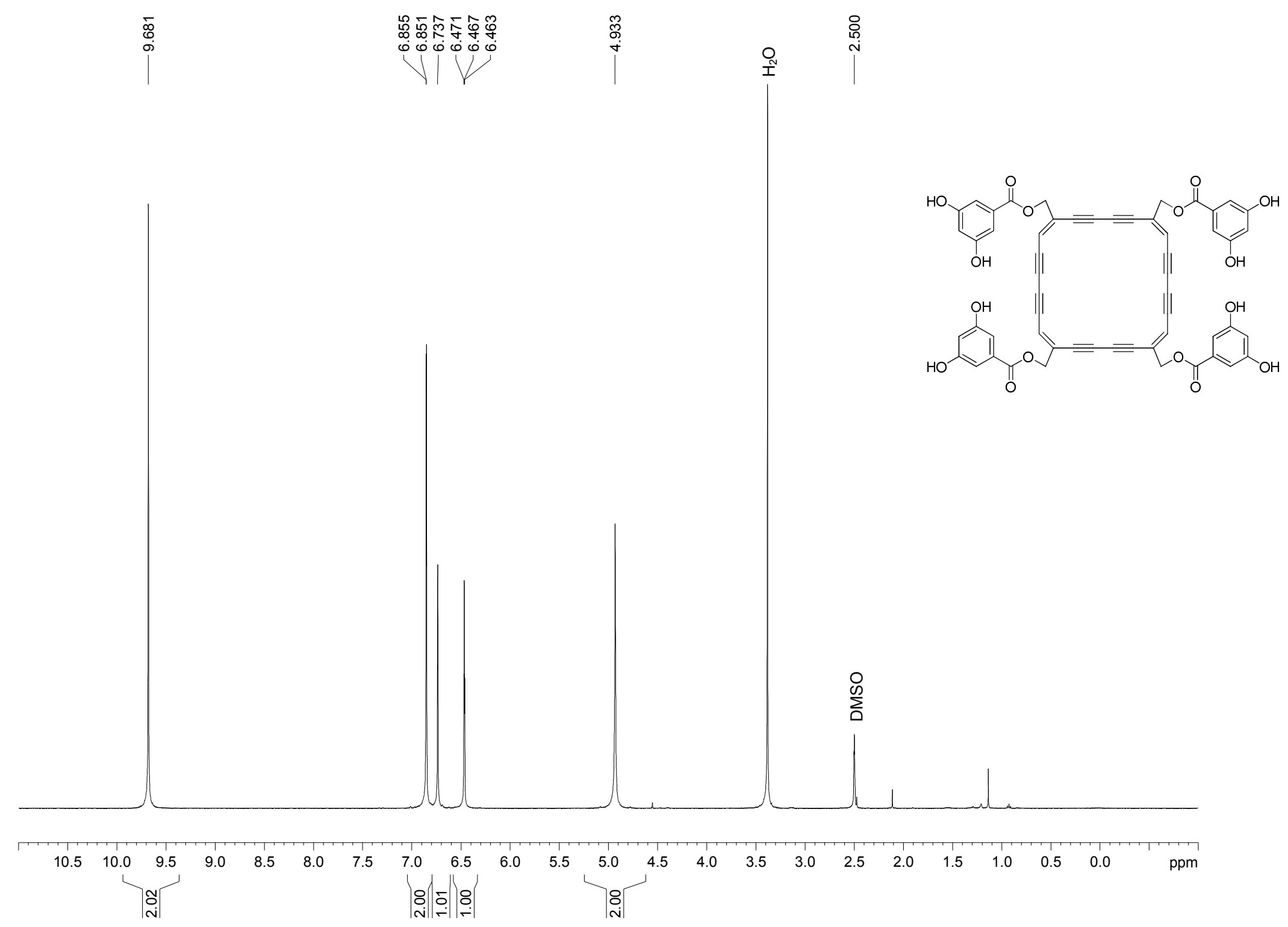

Figure S17. ${ }^{1} \mathrm{H}$ NMR spectrum of $\mathbf{1 d}\left(\mathrm{DMSO}-d_{6}, 500 \mathrm{MHz}\right)$. 


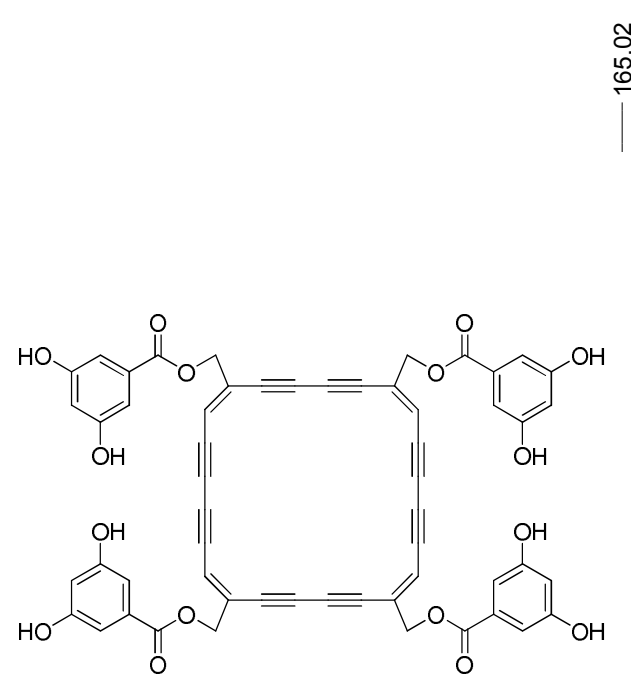

$\overbrace{\substack{0 \\ 0}}^{\infty}$

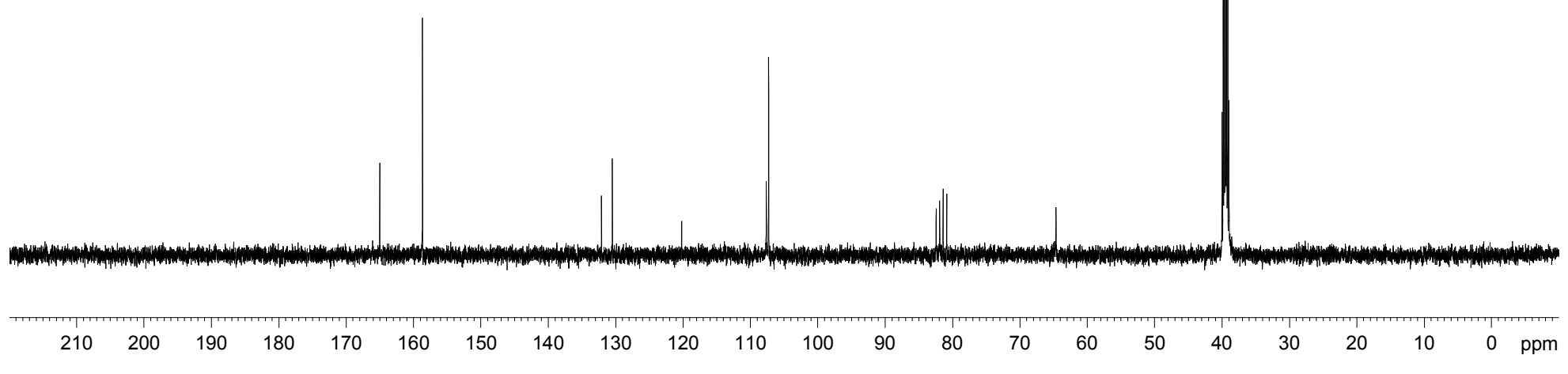

Figure S18. ${ }^{13} \mathrm{C}$ NMR spectrum of $1 \mathrm{~d}\left(\mathrm{DMSO}-d_{6}, 126 \mathrm{MHz}\right)$ 


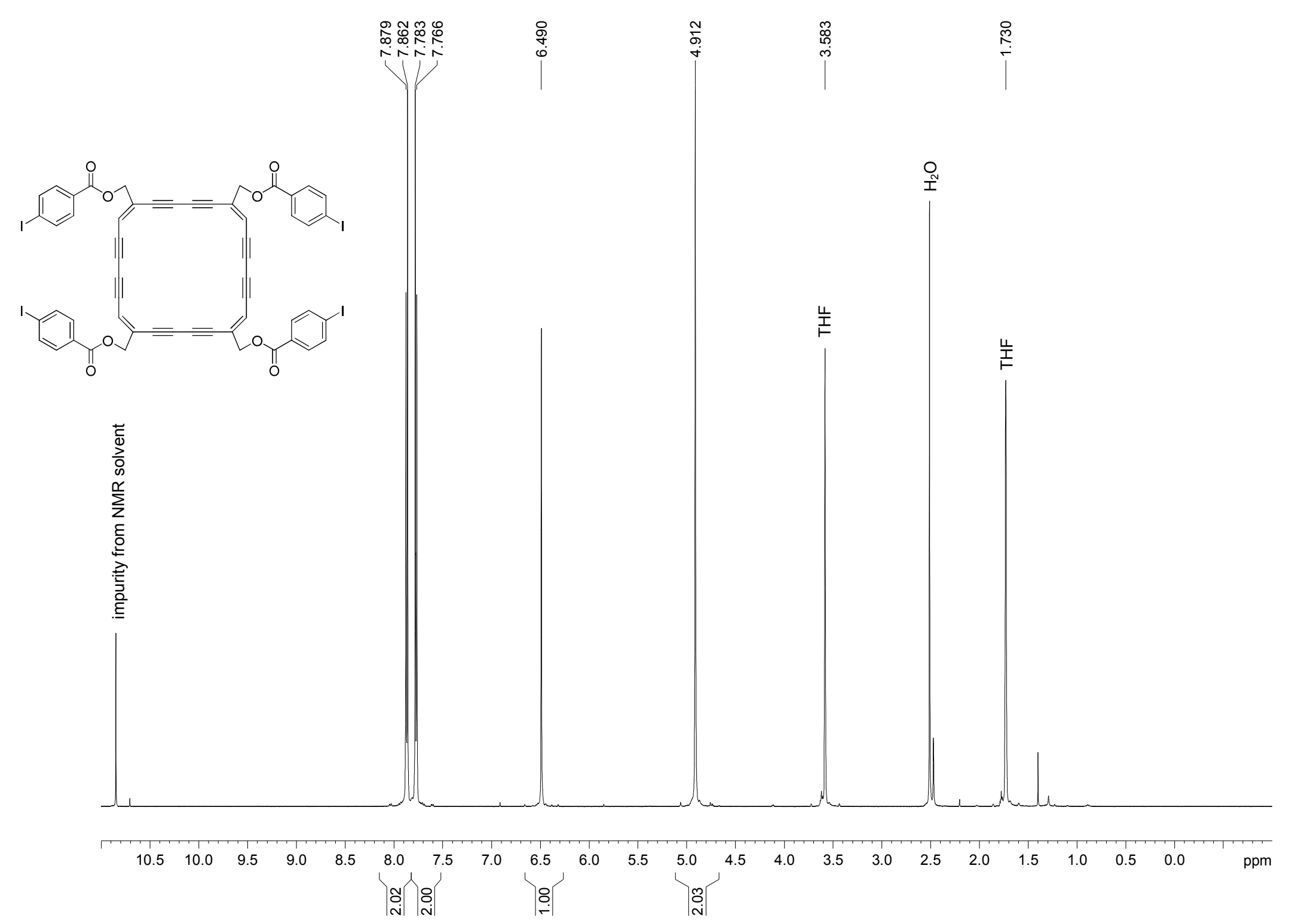

Figure S19. ${ }^{1} \mathrm{H}$ NMR spectrum of 1 e (THF- $\left.d_{8}, 500 \mathrm{MHz}\right)$. 


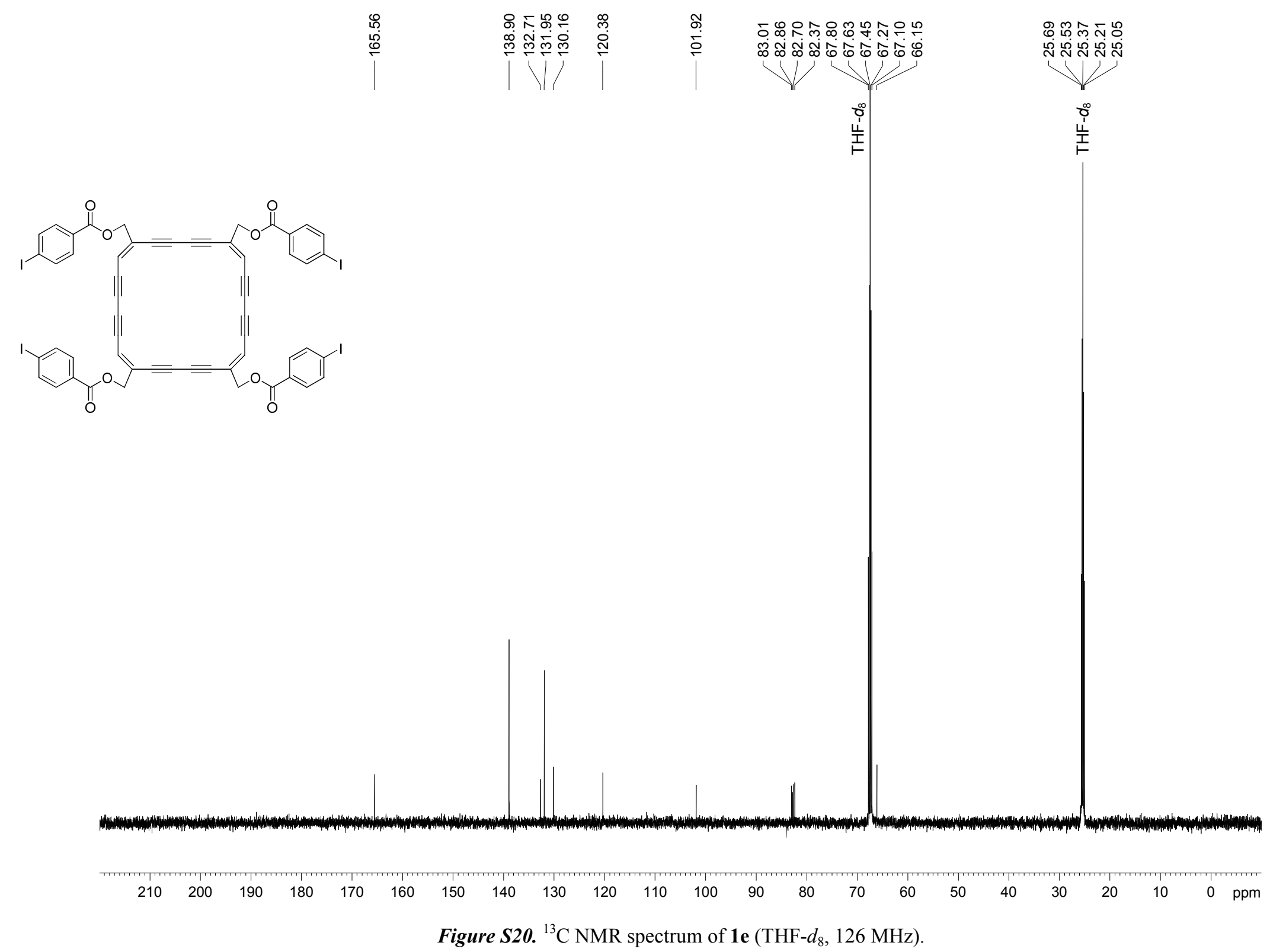




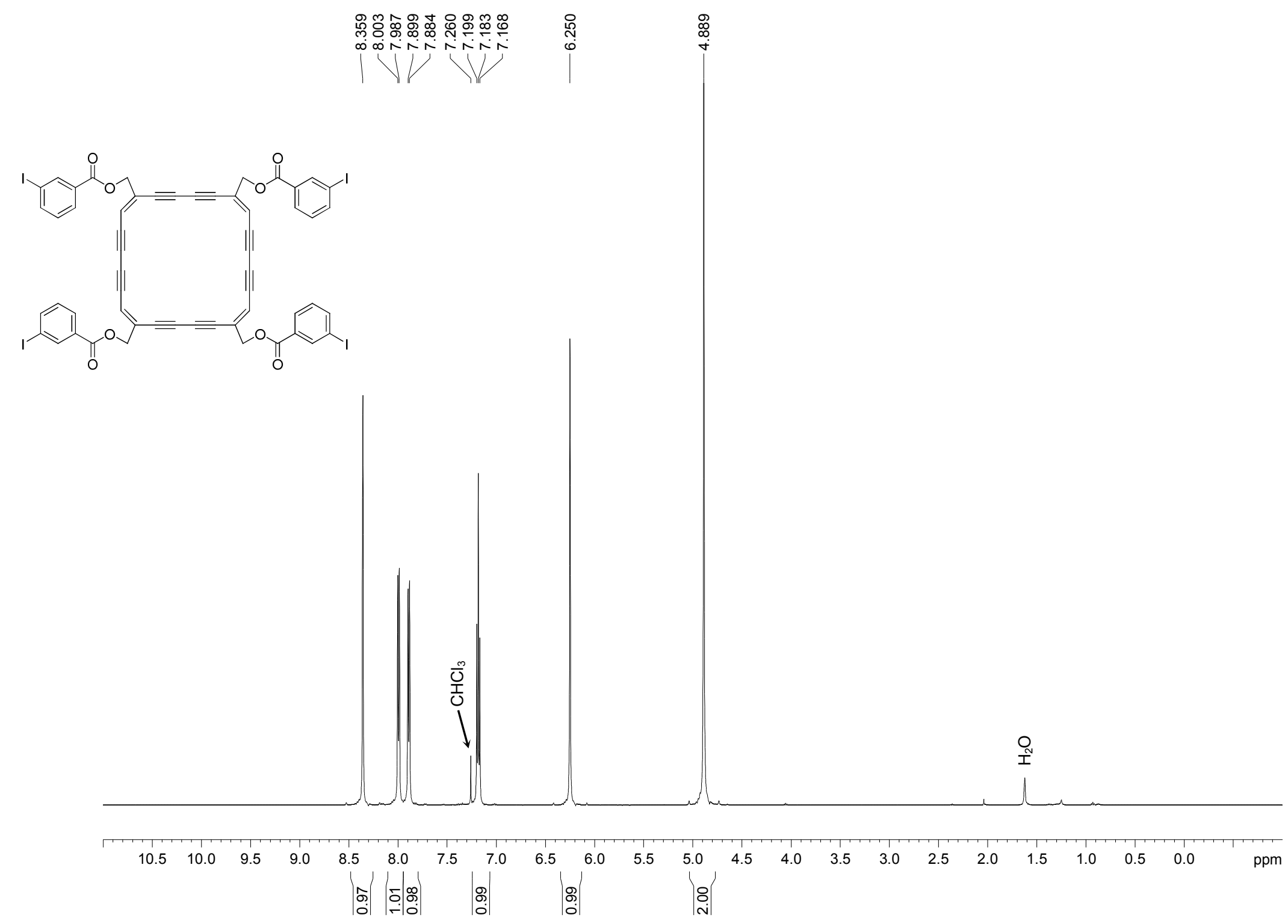

Figure S21. ${ }^{1} \mathrm{H}$ NMR spectrum of $\mathbf{1 f}\left(\mathrm{CDCl}_{3}, 500 \mathrm{MHz}\right)$. 

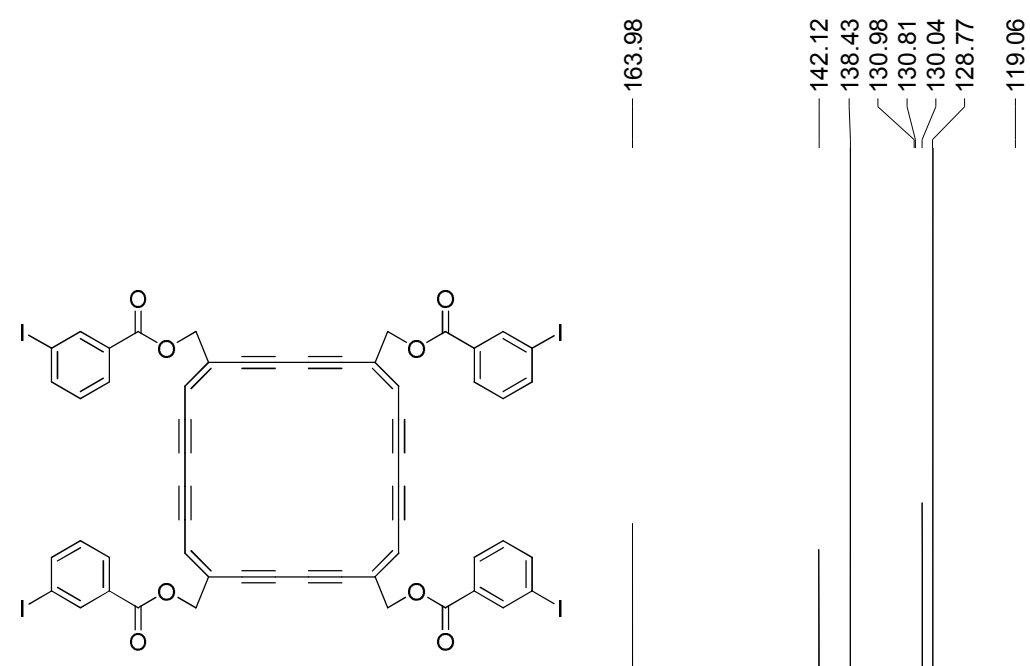

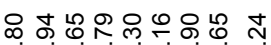

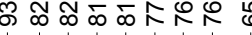

仓ั

(1)

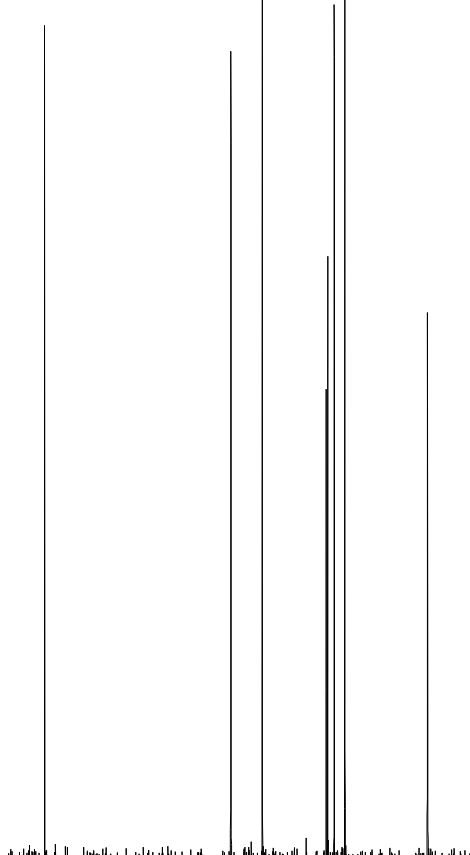

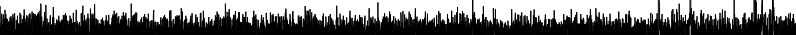

W
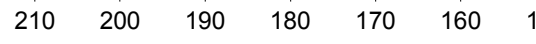

130

100

80

$70 \quad 60$

$50 \quad 40$

30

Figure S22. ${ }^{13} \mathrm{C}$ NMR spectrum of $\mathbf{1 f}\left(\mathrm{CDCl}_{3}, 126 \mathrm{MHz}\right)$. 


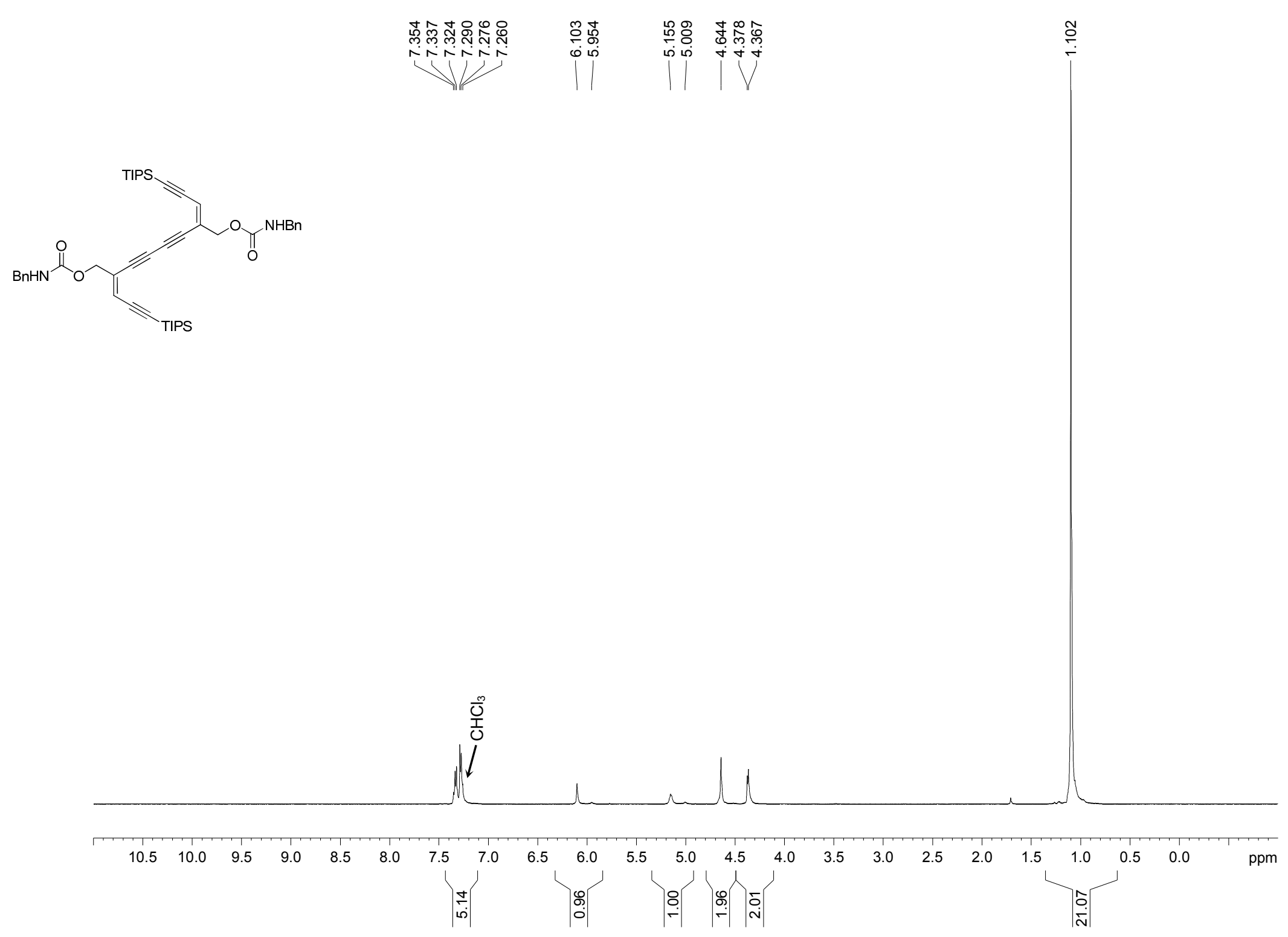

Figure S23. ${ }^{1} \mathrm{H}$ NMR spectrum of $\mathbf{4 a}\left(\mathrm{CDCl}_{3}, 500 \mathrm{MHz}\right)$. 


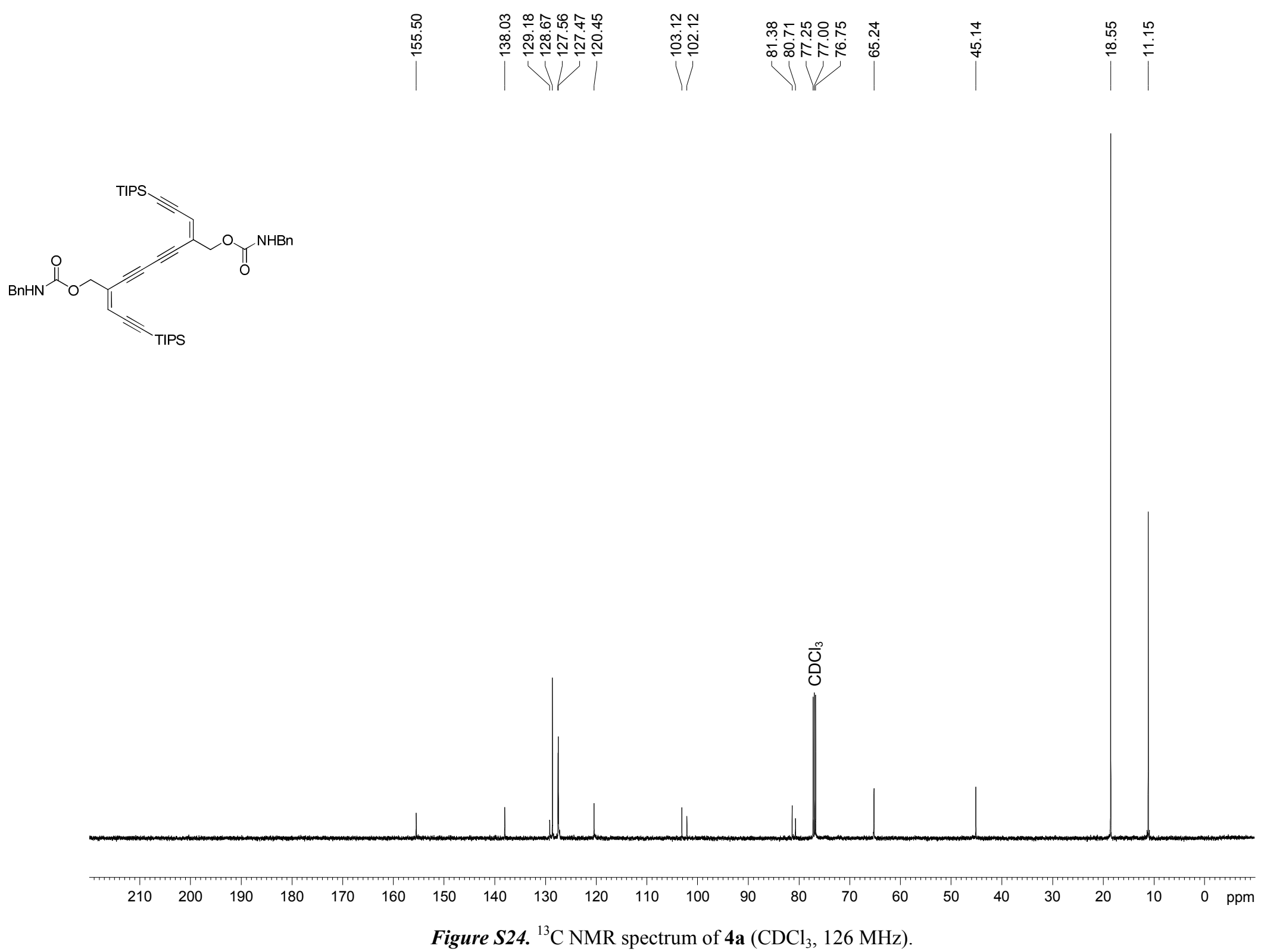




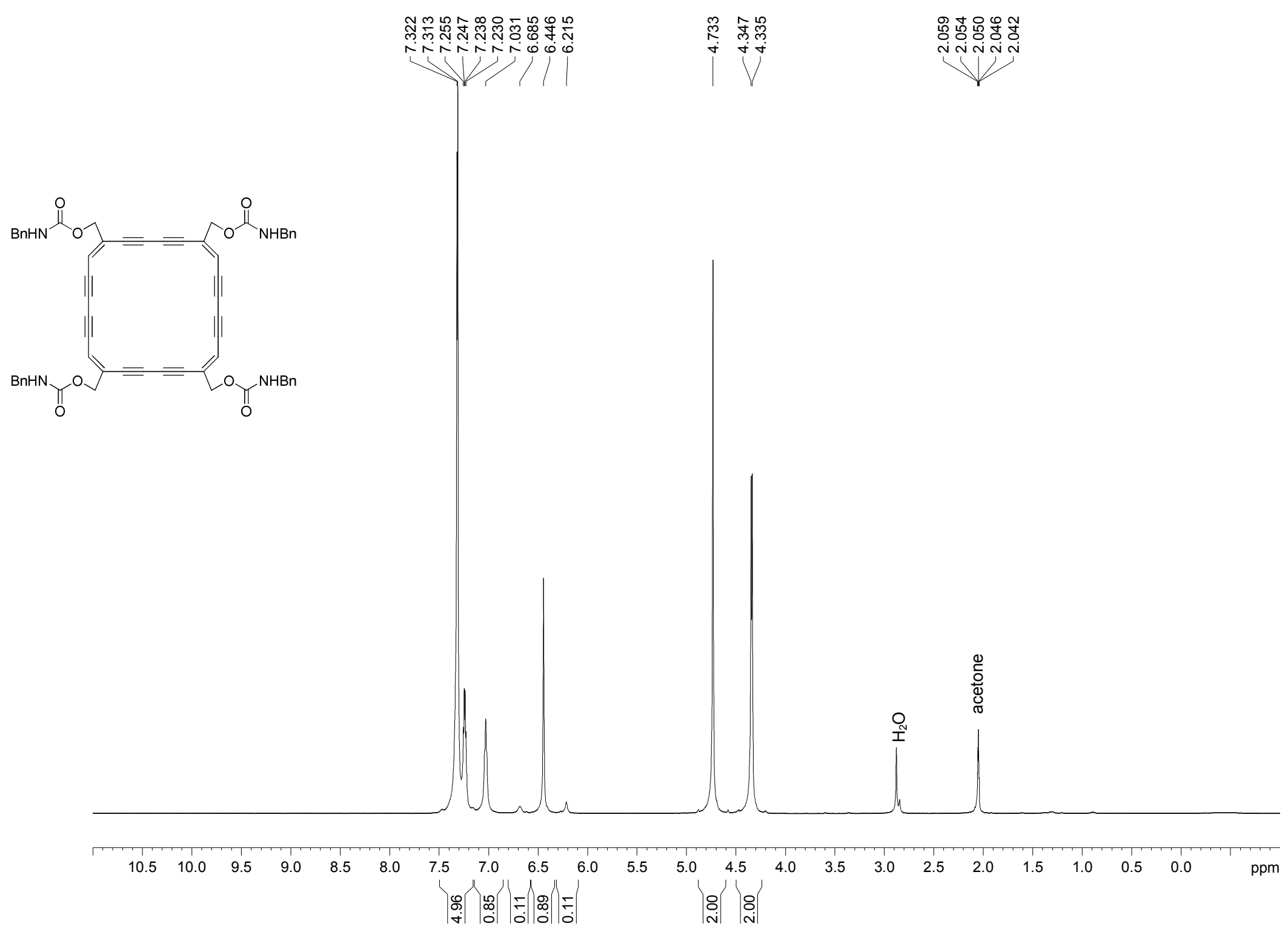

Figure S25. ${ }^{1} \mathrm{H}$ NMR spectrum of $\mathbf{1 g}$ (acetone- $d_{6}, 500 \mathrm{MHz}$ ). 


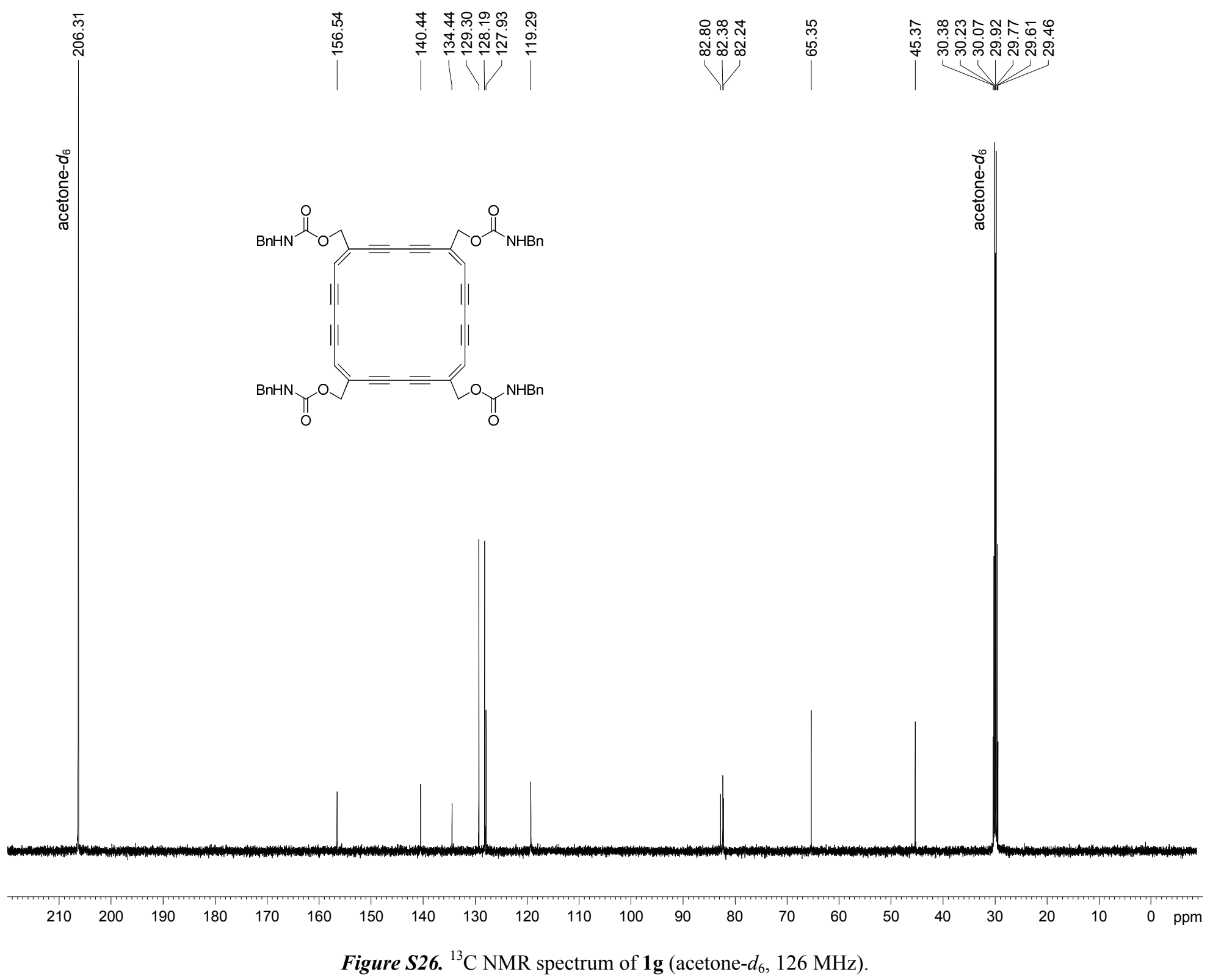




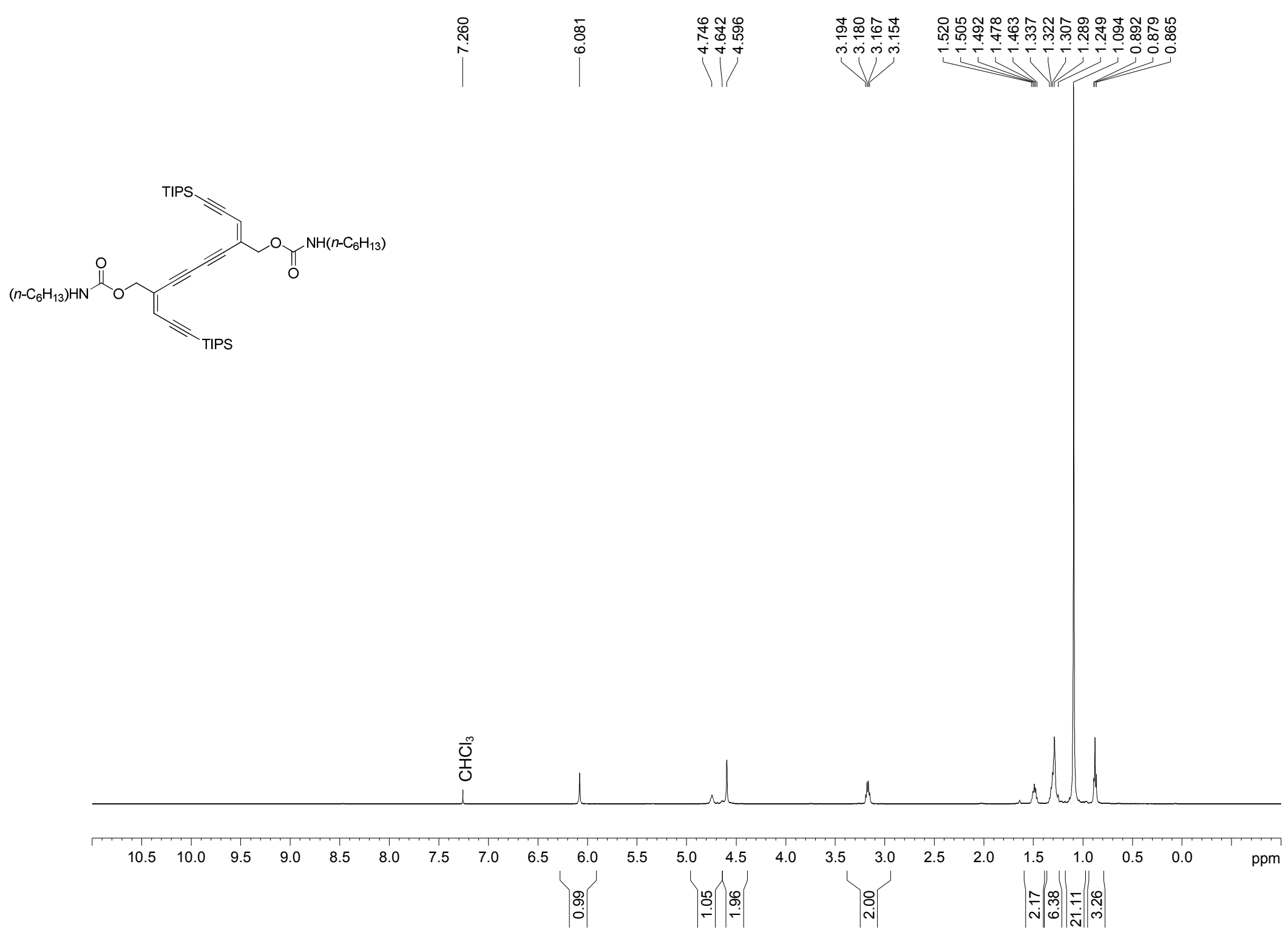

Figure S27. ${ }^{1} \mathrm{H}$ NMR spectrum of $\mathbf{4 b}\left(\mathrm{CDCl}_{3}, 500 \mathrm{MHz}\right)$. 


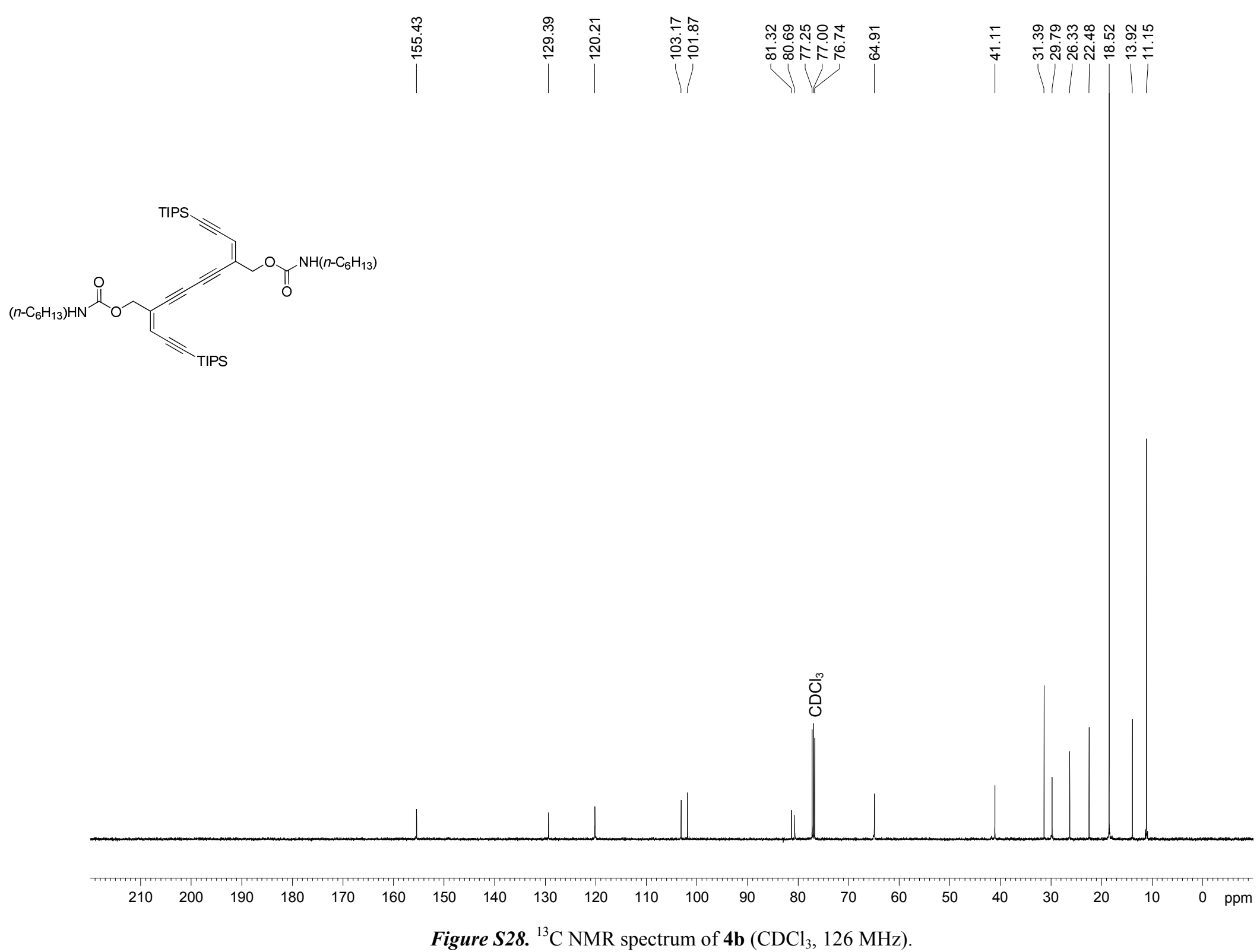




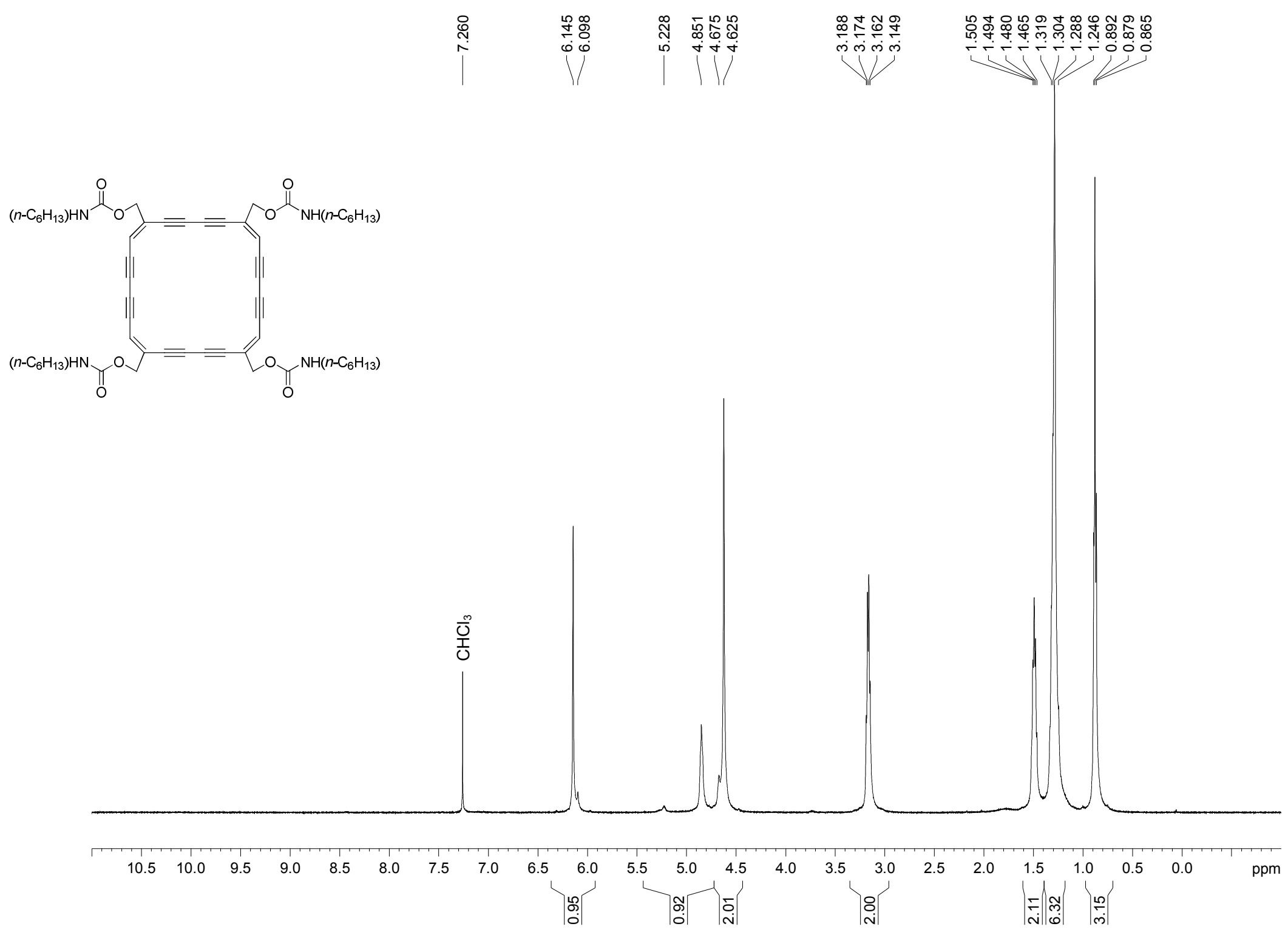

Figure S29. ${ }^{1} \mathrm{H}$ NMR spectrum of $\mathbf{1 h}\left(\mathrm{CDCl}_{3}, 500 \mathrm{MHz}\right)$. 

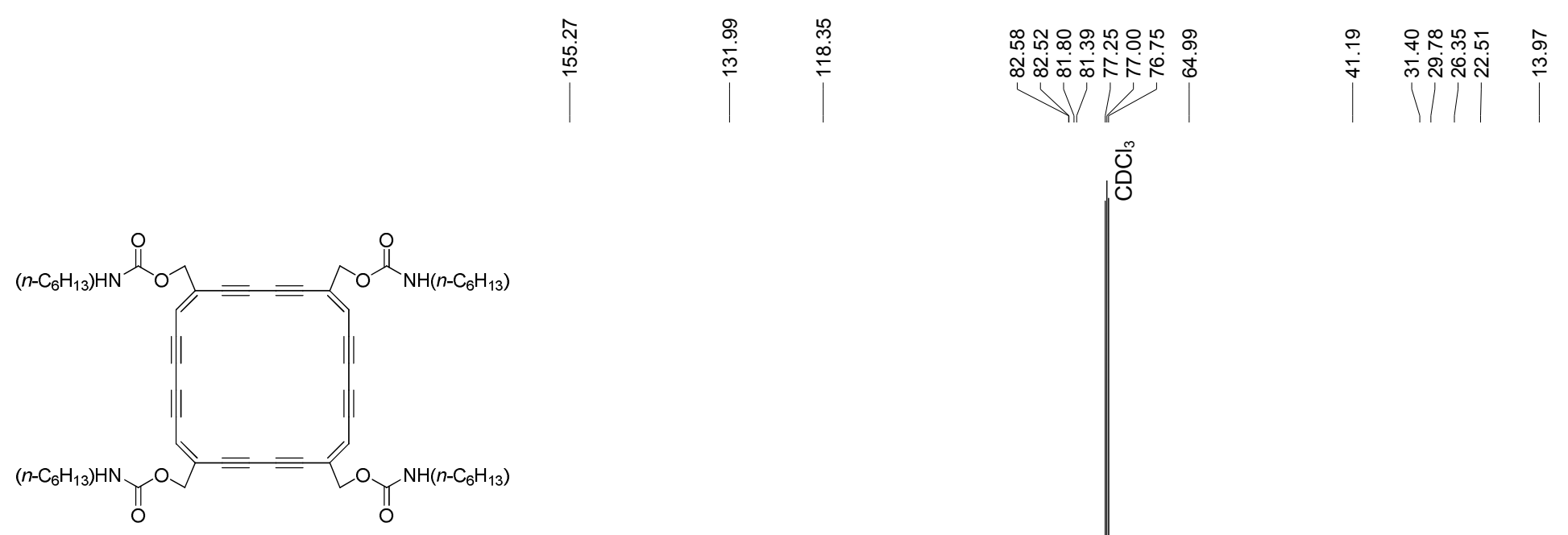

递
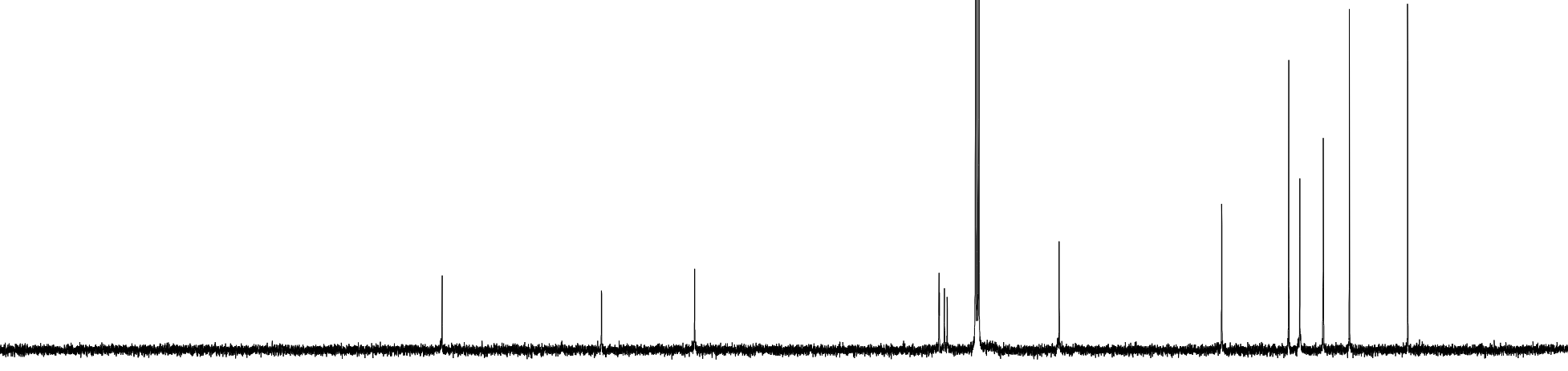

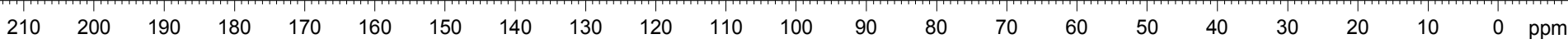

Figure S30. ${ }^{13} \mathrm{C}$ NMR spectrum of $\mathbf{1 h}\left(\mathrm{CDCl}_{3}, 126 \mathrm{MHz}\right)$. 


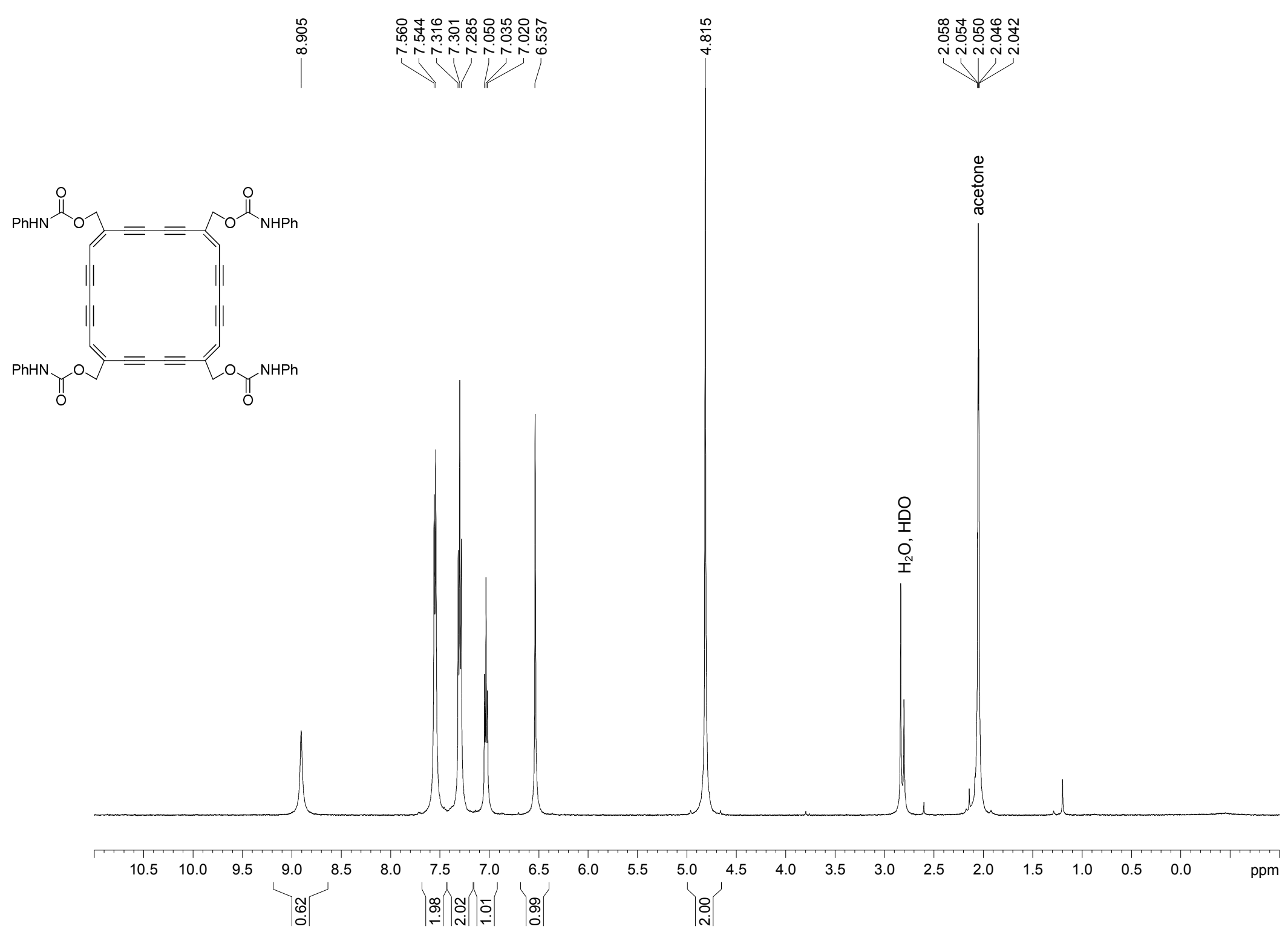

Figure S31. ${ }^{1} \mathrm{H}$ NMR spectrum of $1 \mathrm{i}$ (acetone- $d_{6}, 500 \mathrm{MHz}$ ). 


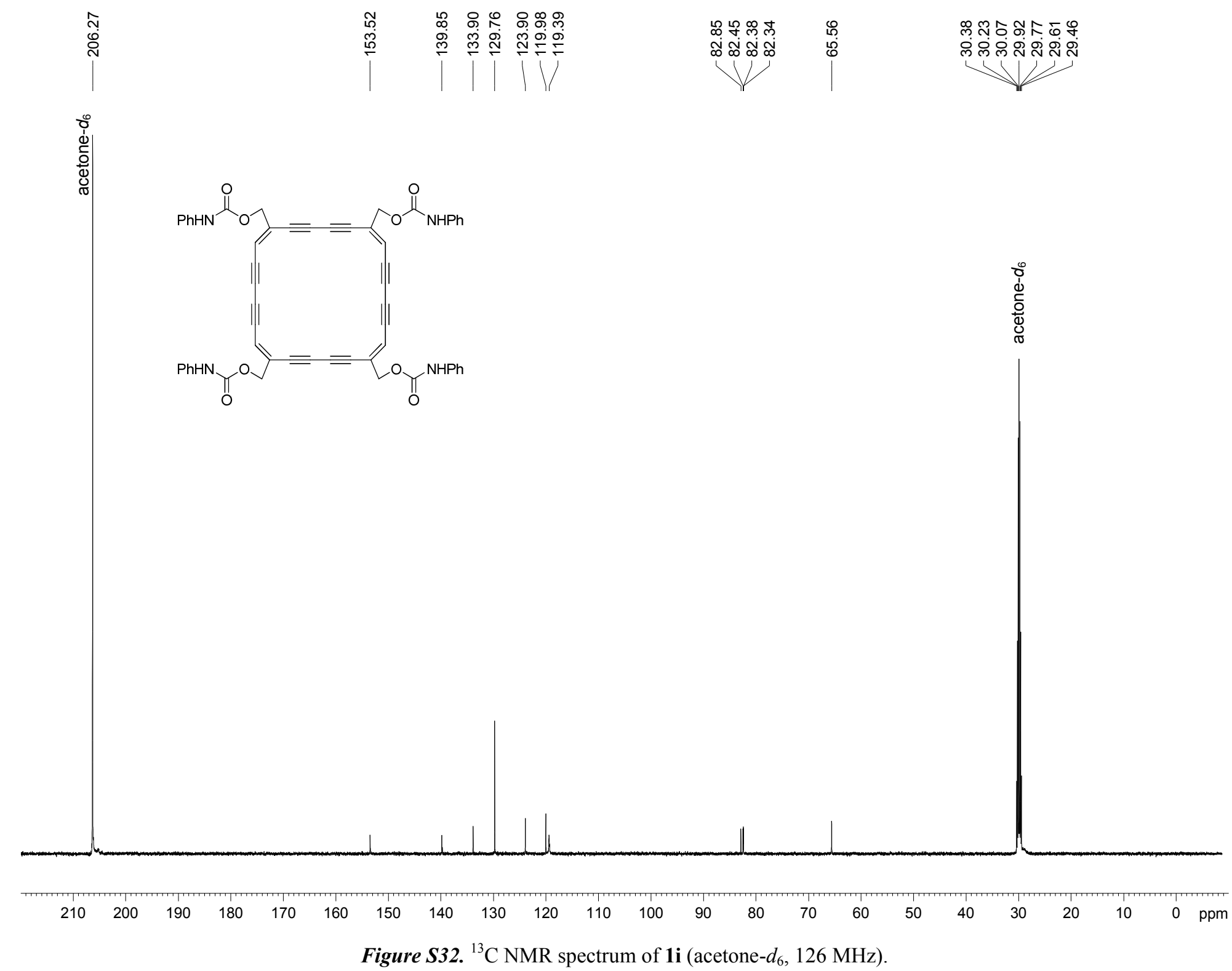




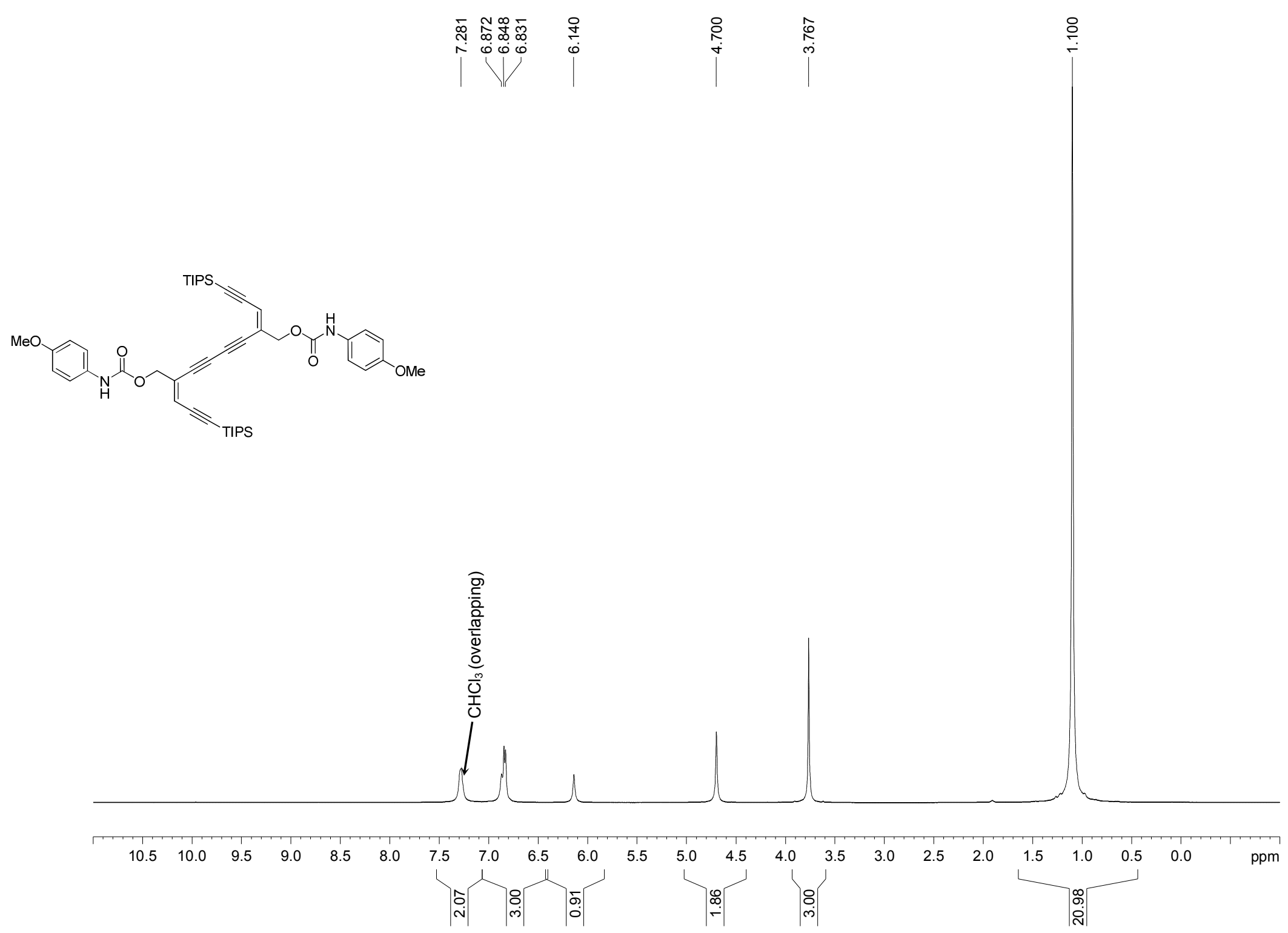

Figure S33. ${ }^{1} \mathrm{H}$ NMR spectrum of $4 \mathrm{c}\left(\mathrm{CDCl}_{3}, 500 \mathrm{MHz}\right)$. 


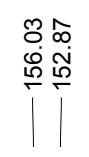

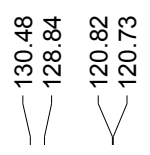

용웜
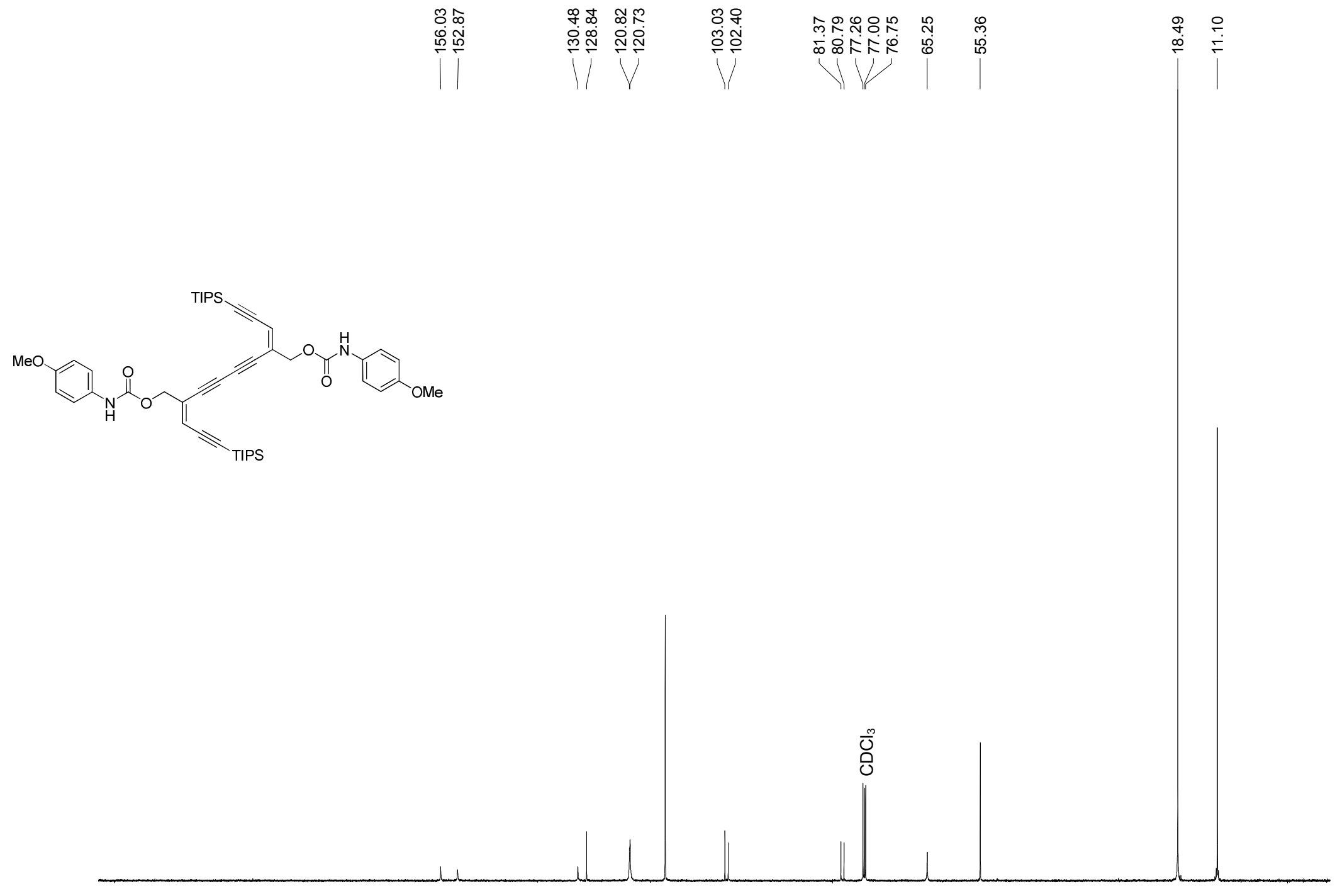

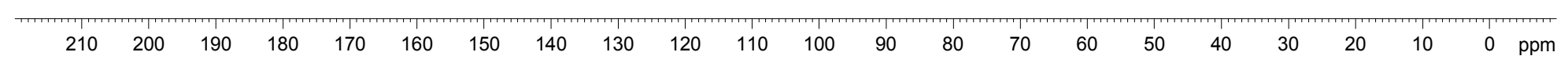

Figure S34. ${ }^{13} \mathrm{C}$ NMR spectrum of $4 \mathrm{c}\left(\mathrm{CDCl}_{3}, 126 \mathrm{MHz}\right)$.

S53 


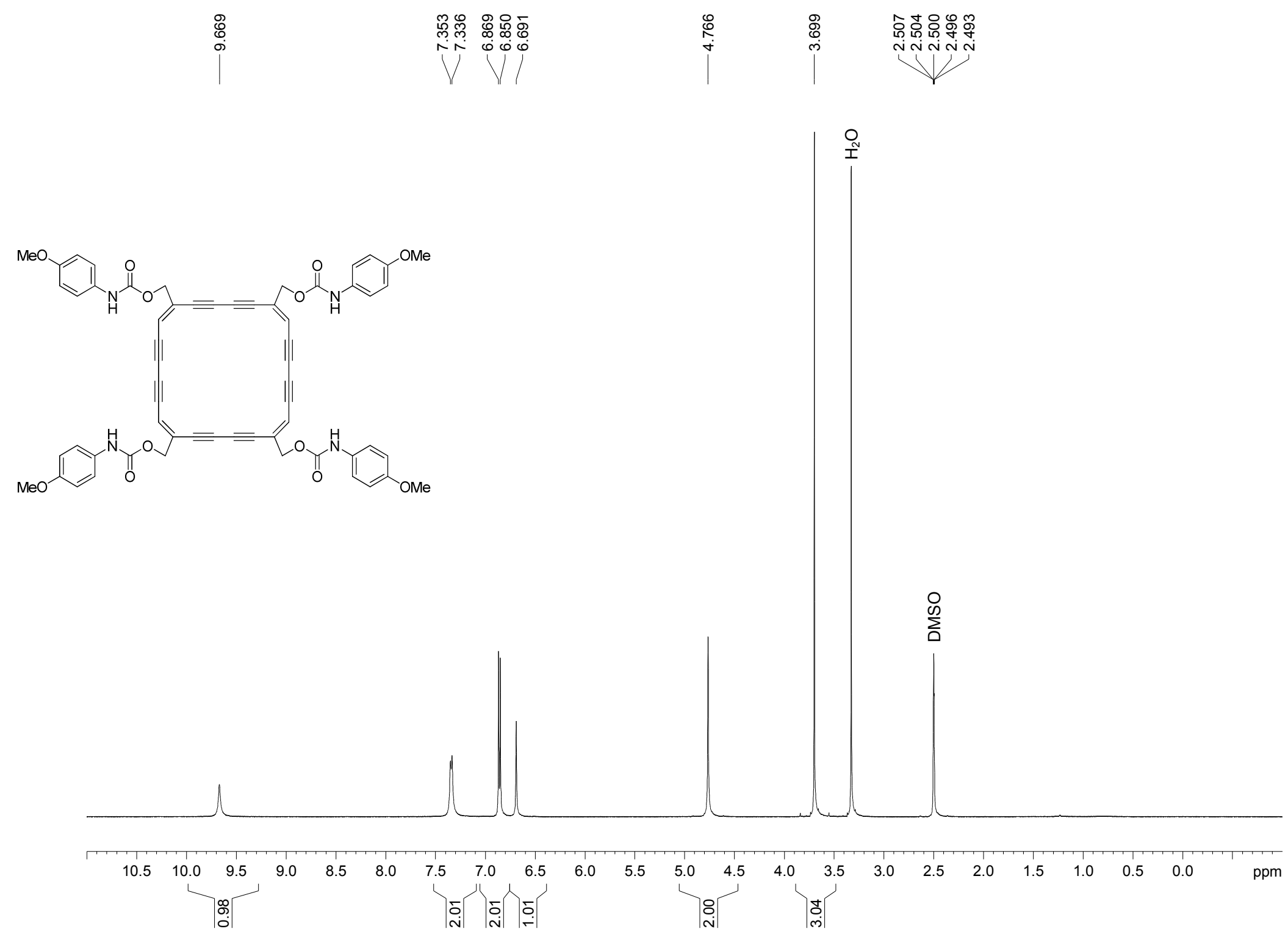

Figure S35. ${ }^{1} \mathrm{H}$ NMR spectrum of $\mathbf{1 j}$ (DMSO- $d_{6}, 500 \mathrm{MHz}$ ). 


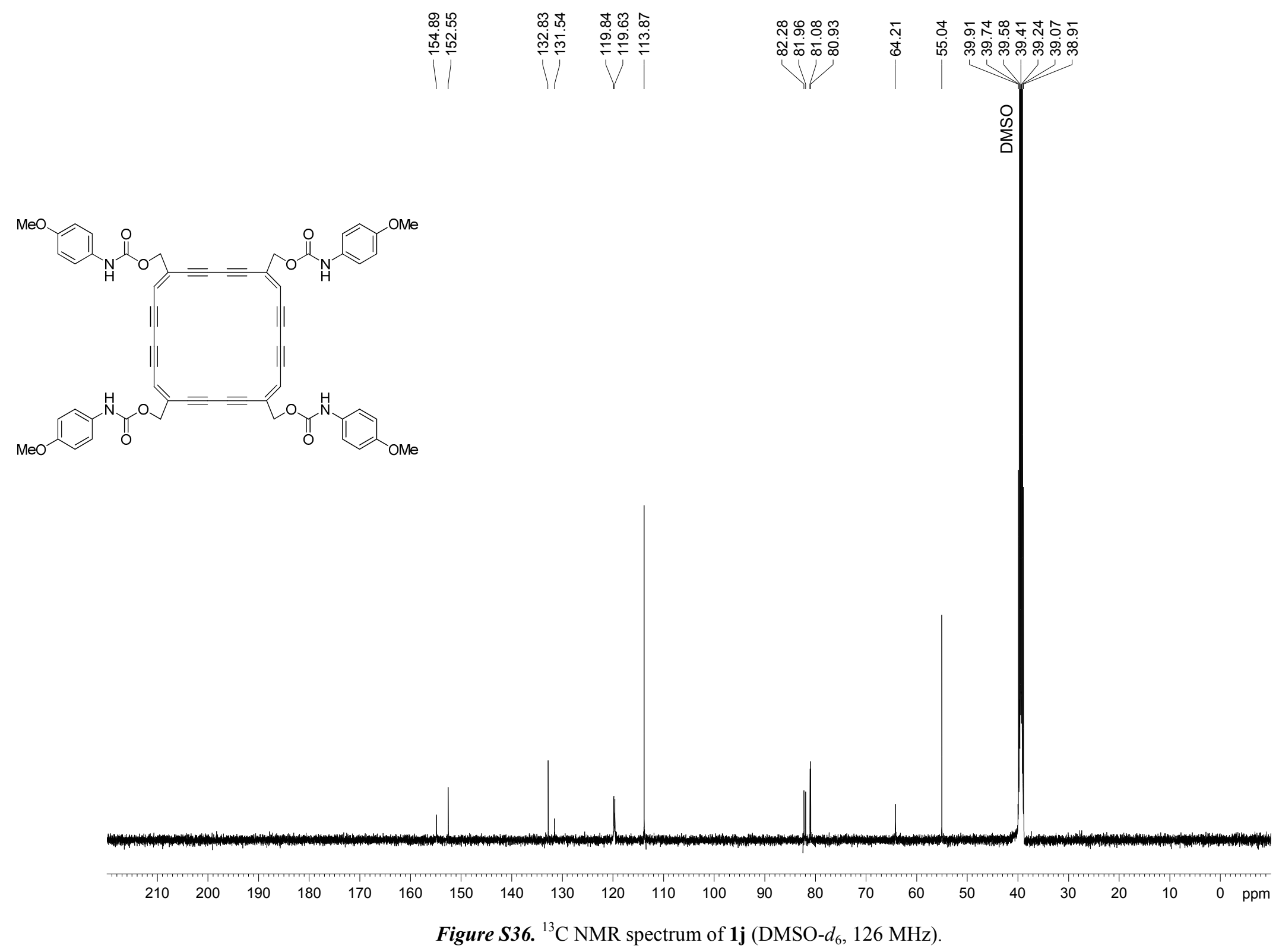




\section{X-ray crystallography and structural analysis}

\subsection{Measurements}

The X-ray intensity data were measured on a Bruker SMART APEX2 CCD-based X-ray diffractometer system equipped with a Mo-target X-ray tube $(\lambda=0.71073 \AA)$ operated at 2250 watts power. The detector was placed at a distance of $6.000 \mathrm{~cm}$ from the crystal.

The data frames were collected using the program APEX2 and processed using the program SAINT routine within APEX2. ${ }^{\mathrm{S} 6}$ The data were corrected for absorption based on the multi-scan technique as implemented in SADABS. Structure solution and refinement were performed using Bruker SHELXTL (Version 6.12) Software Package. The diffuse electron density peaks from disordered solvents were treated using the SQUEEZE routine of PLATON. Mercury CSD 2.4 and Diamond 3.2d were used to visualize crystal structures and to calculate distances and angles.

\subsection{Thermal ellipsoid plots}

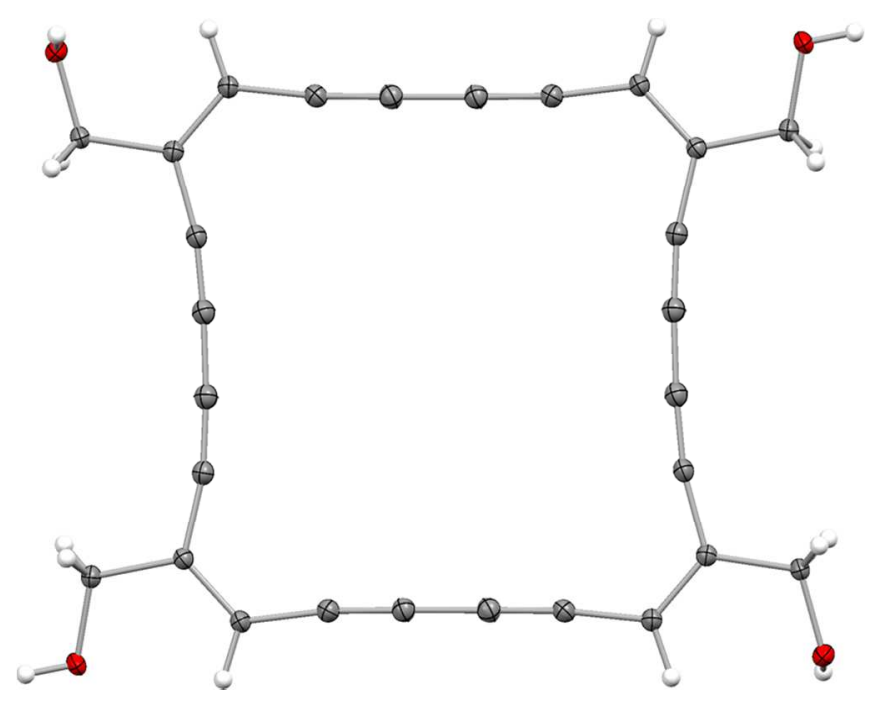

Figure S37. Thermal-ellipsoid plot for the pseudopolymorph 1a-I at 50\% probability. Solvent molecules are omitted for clarity. 


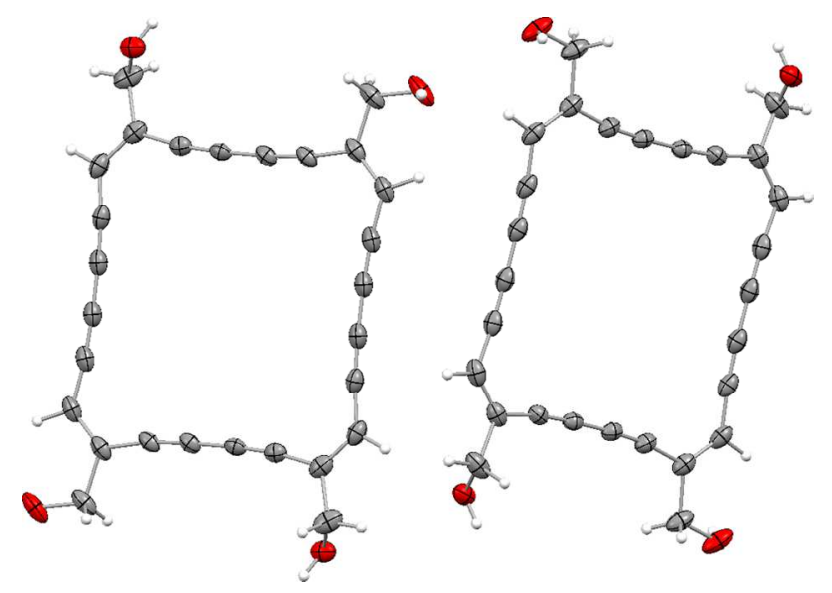

Figure S38. Thermal-ellipsoid plot for the pseudopolymorph 1a-II at 50\% probability. Solvent molecules are omitted for clarity.

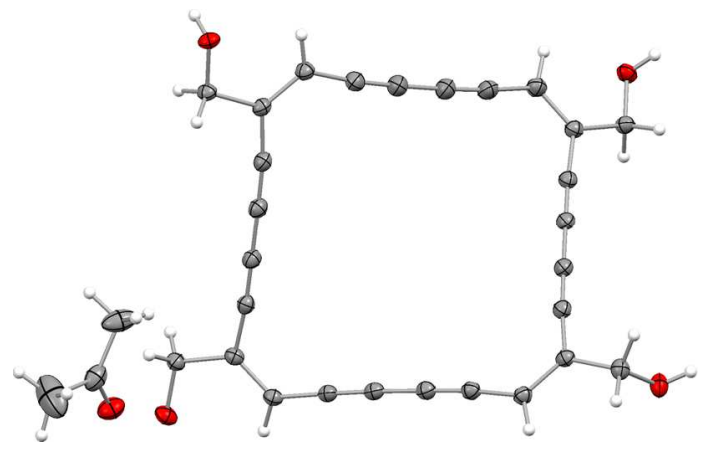

Figure S39. Thermal-ellipsoid plot for the pseudopolymorph 1a-II at 50\% probability.

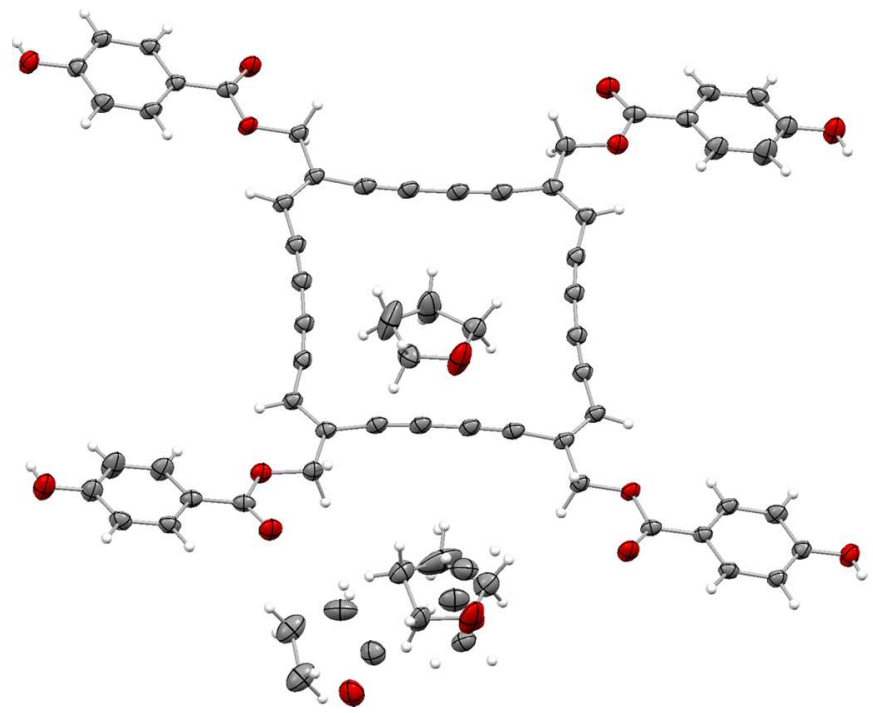

Figure S40. Thermal-ellipsoid plot for the crystal structure of $\mathbf{1 b}$ at $50 \%$ probability. 


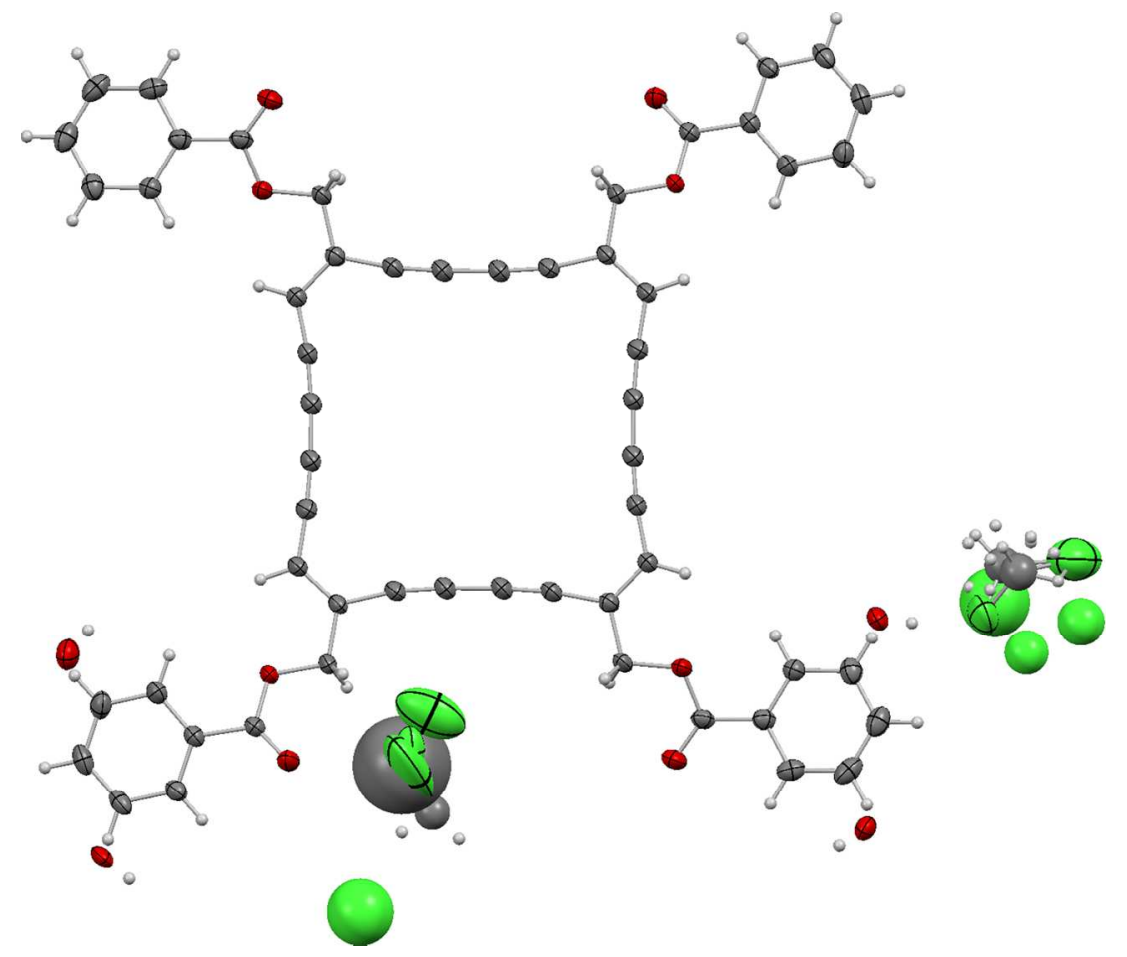

Figure S41. Thermal-ellipsoid plot for the crystal structure of $1 \mathbf{c}$ at $50 \%$ probability.

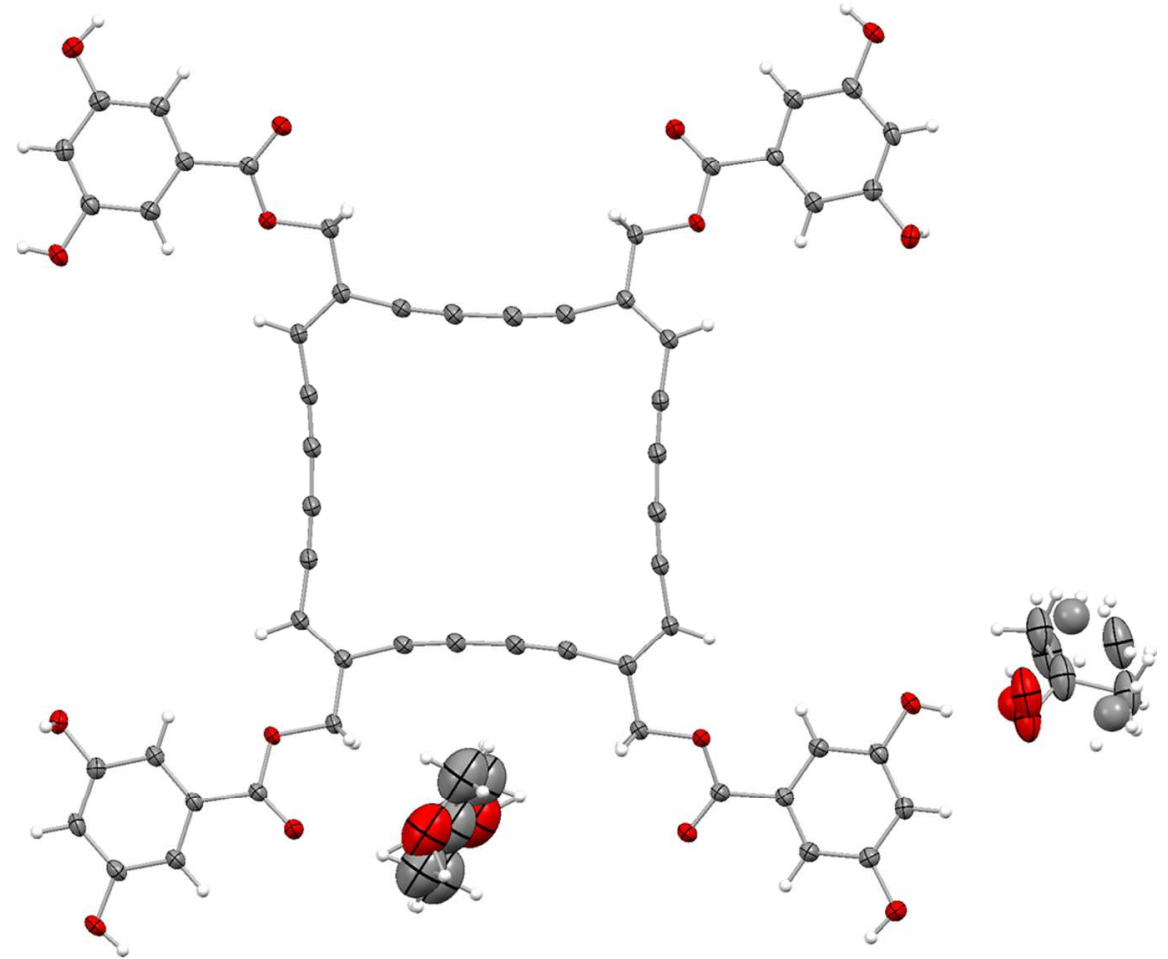

Figure S42. Thermal-ellipsoid plot for the crystal structure of $\mathbf{1 d}$ at $50 \%$ probability. 


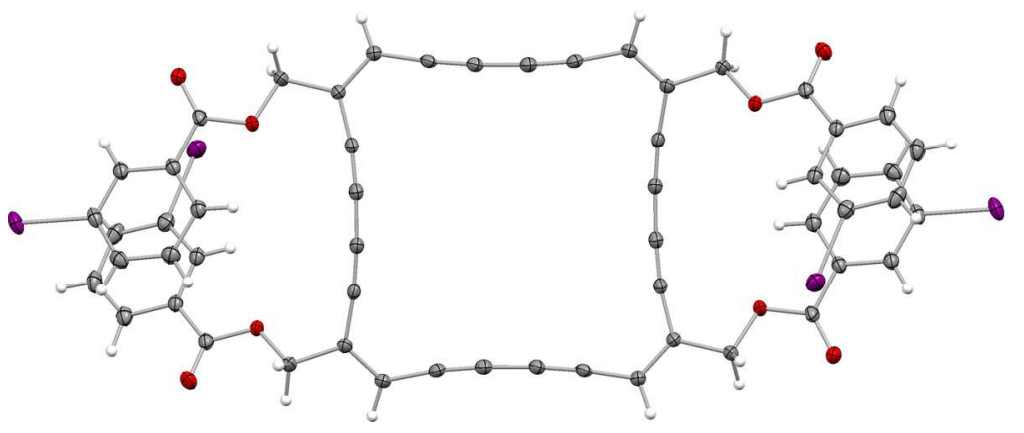

Figure S43. Thermal-ellipsoid plot for the crystal structure of $\mathbf{1 f}$ at $50 \%$ probability.

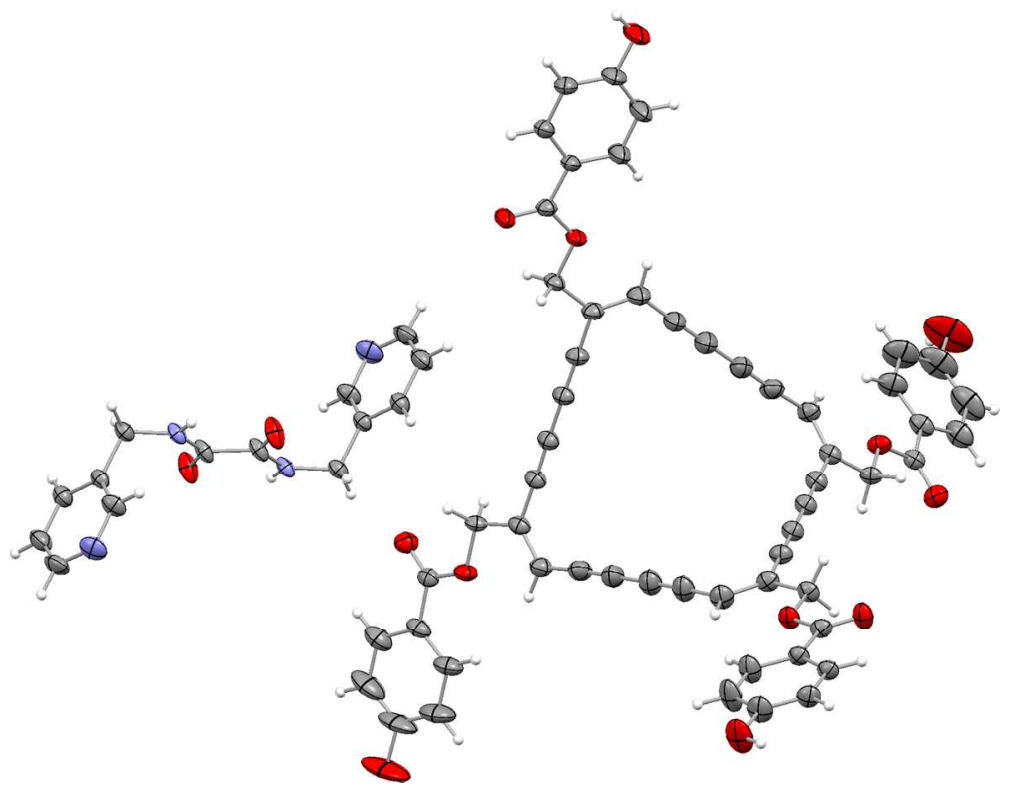

Figure S44. Thermal-ellipsoid plot for the crystal structure of $\mathbf{1 b} \cdot \mathbf{2 b}$ at $50 \%$ probability.

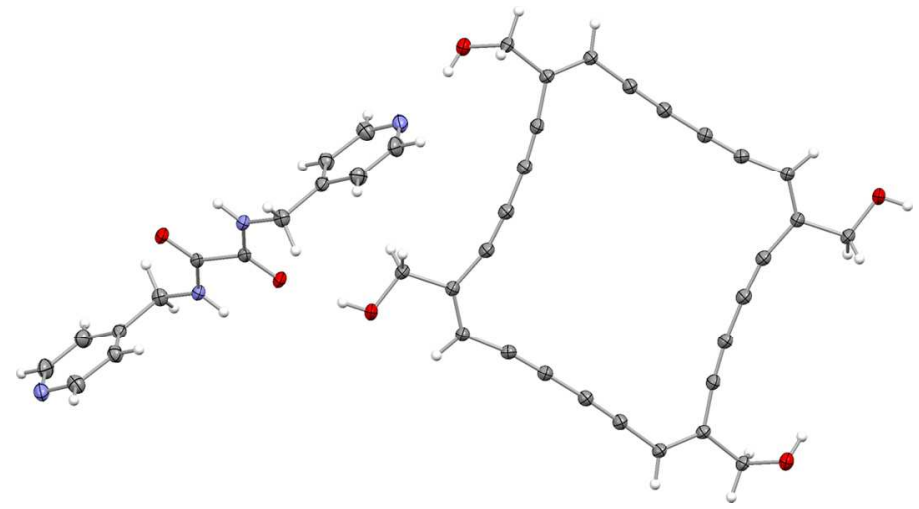

Figure S45. Thermal-ellipsoid plot for the crystal structure of $1 \mathbf{a} \cdot \mathbf{2 a}$ at $50 \%$ probability. 


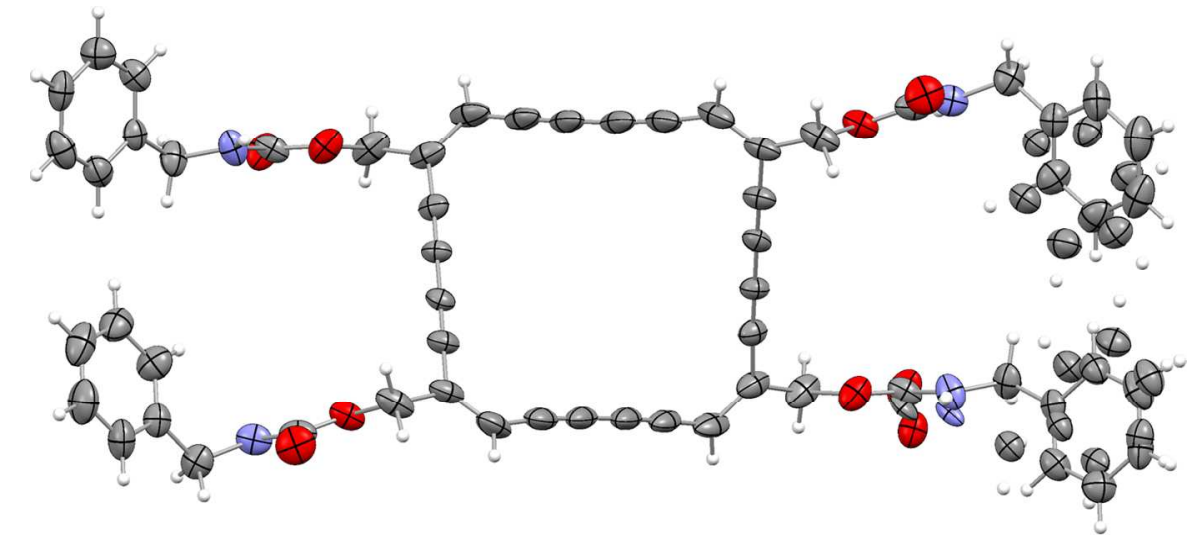

Figure S46. Thermal-ellipsoid plot for the pseudopolymorph $\mathbf{1 g - I}$ at 50\% probability.
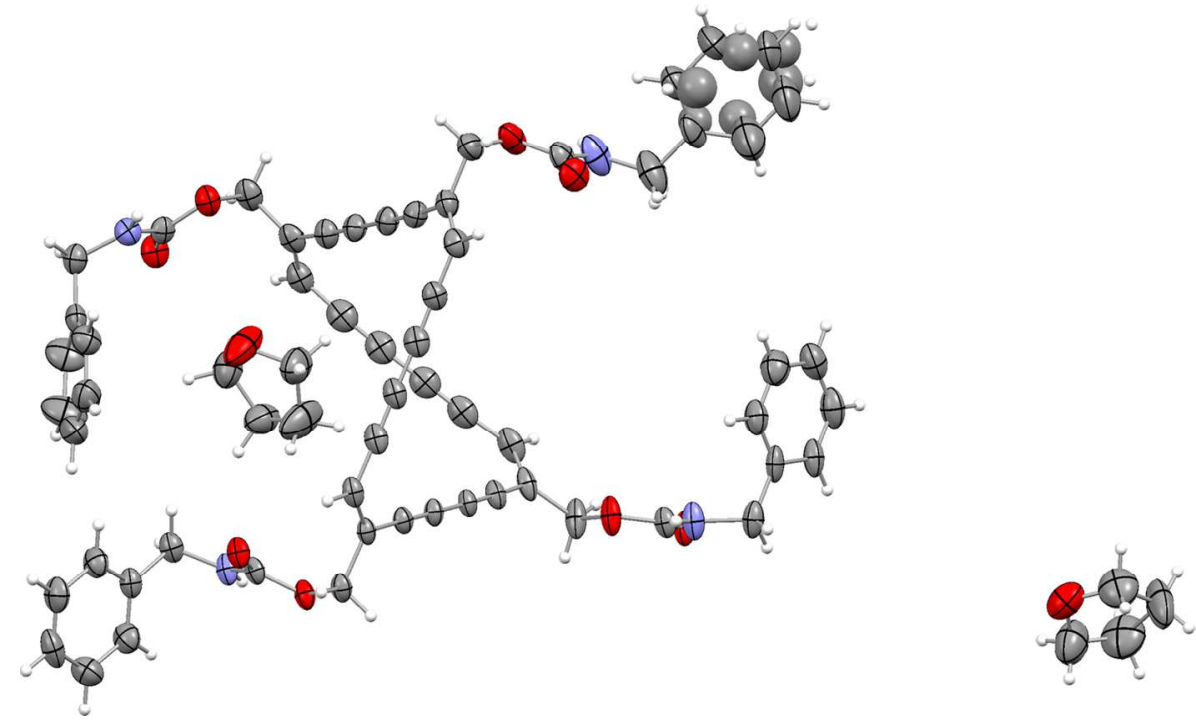

Figure S47. Thermal-ellipsoid plot for the pseudopolymorph 1g-II at 50\% probability.

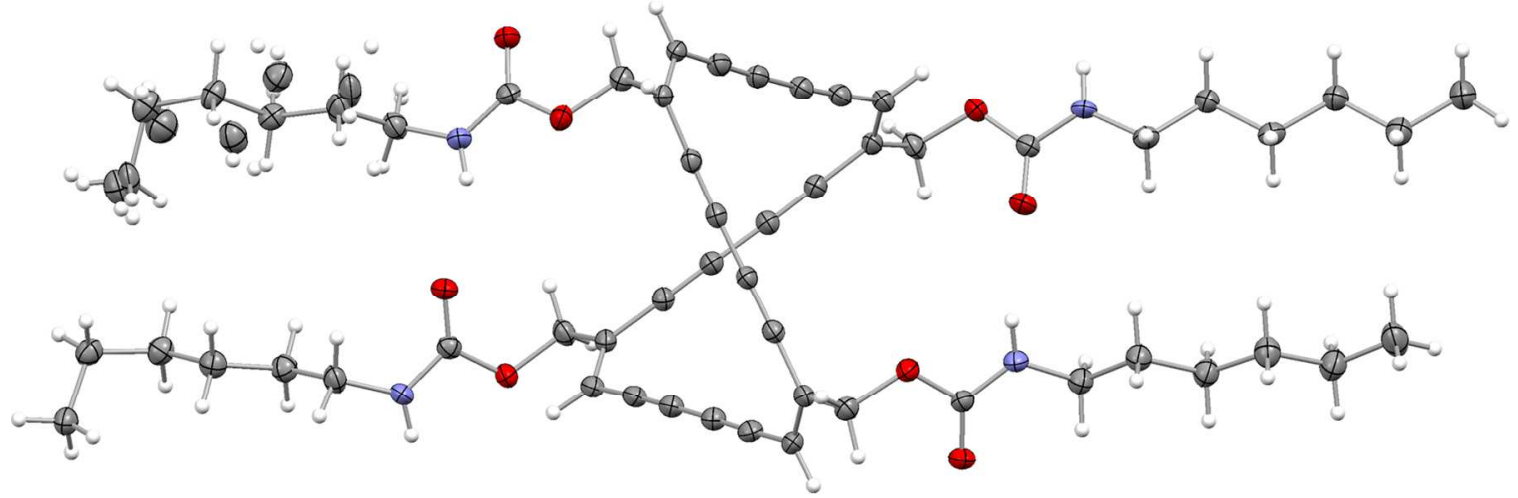

Figure S48. Thermal-ellipsoid plot for the crystal structure of $\mathbf{1 h}$ at $50 \%$ probability. 


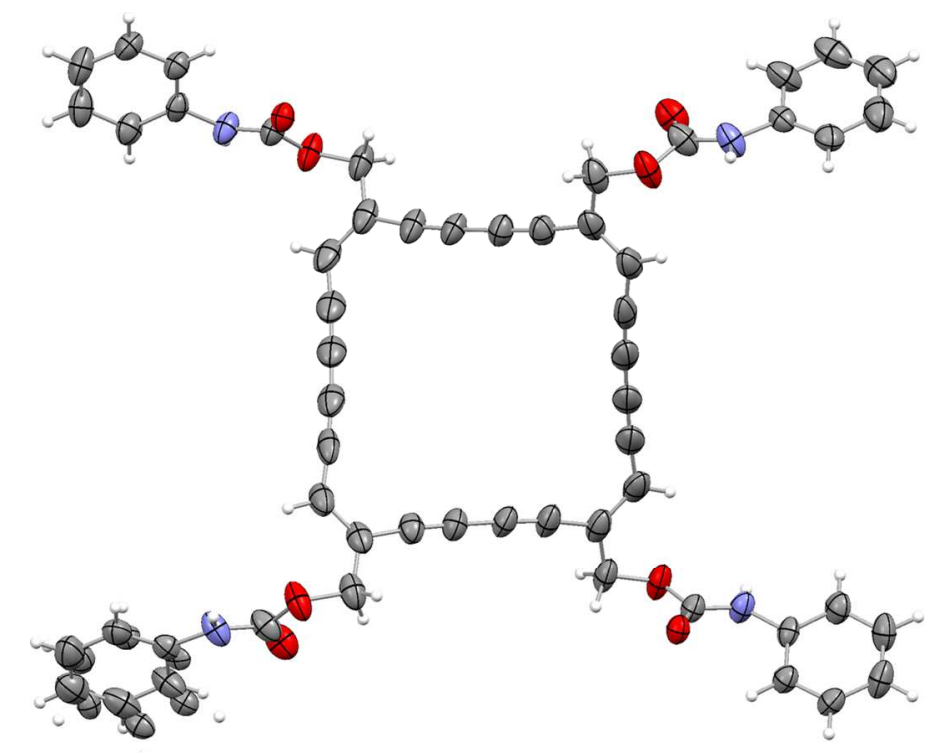

Figure S49. Thermal-ellipsoid plot for the crystal structure of $\mathbf{1 h}$ at $50 \%$ probability.

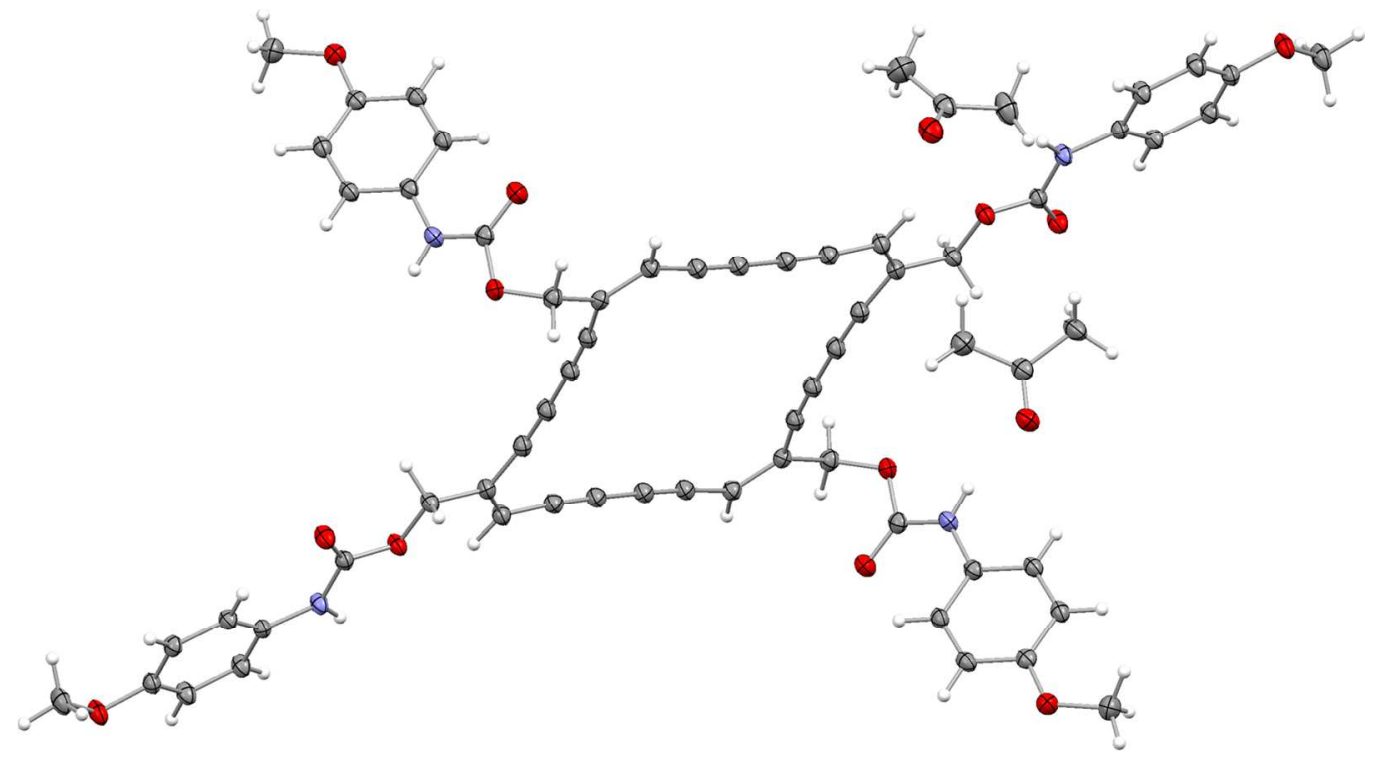

Figure S50. Thermal-ellipsoid plot for the crystal structure of $\mathbf{1 i}$ at $50 \%$ probability. 


\section{Structural analysis of tetraol 1a by density functional theory}

\subsection{Full citation for Gaussian 09}

Gaussian 09, Revision A.02, Frisch, M. J.; Trucks, G. W.; Schlegel, H. B.; Scuseria, G. E.; Robb, M. A.; Cheeseman, J. R.; Scalmani, G.; Barone, V.; Mennucci, B.; Petersson, G. A.; Nakatsuji, H.; Caricato, M.; Li, X.; Hratchian, H. P.; Izmaylov, A. F.; Bloino, J.; Zheng, G.; Sonnenberg, J. L.; Hada, M.; Ehara, M.; Toyota, K.; Fukuda, R.; Hasegawa, J.; Ishida, M.; Nakajima, T.; Honda, Y.; Kitao, O.; Nakai, H.; Vreven, T.; Montgomery, Jr., J. A.; Peralta, J. E.; Ogliaro, F.; Bearpark, M.; Heyd, J. J.; Brothers, E.; Kudin, K. N.; Staroverov, V. N.; Kobayashi, R.; Normand, J.; Raghavachari, K.; Rendell, A.; Burant, J. C.; Iyengar, S. S.; Tomasi, J.; Cossi, M.; Rega, N.; Millam, N. J.; Klene, M.; Knox, J. E.; Cross, J. B.; Bakken, V.; Adamo, C.; Jaramillo, J.; Gomperts, R.; Stratmann, R. E.; Yazyev, O.; Austin, A. J.; Cammi, R.; Pomelli, C.; Ochterski, J. W.; Martin, R. L.; Morokuma, K.; Zakrzewski, V. G.; Voth, G. A.; Salvador, P.; Dannenberg, J. J.; Dapprich, S.; Daniels, A. D.; Farkas, Ö.; Foresman, J. B.; Ortiz, J. V.; Cioslowski, J.; Fox, D. J. Gaussian, Inc., Wallingford CT, 2009.

\subsection{Method and results}

All calculations were performed using the Gaussian 09 program suite. Geometry optimizations were performed using tight convergence criteria. Vibrational frequencies were computed for all optimized structures to verify that these structures were minima or first-order saddle points.

The energy required to deform the dehydro[24]annulene framework from the most stable nonplanar conformation to the fully planarized conformation was estimated for tetraol 1a by several different methods as summarized in Table S1. The nonplanar structures were obtained as follows: First, the experimentally obtained planar structure in pseudopolymorph 1a-I was "relaxed" to a nonplanar conformation without any constraints; second, conformations of the four substituents were varied to several different orientations; finally, the modified structures were all optimized again in order to determine the most stable conformation. Alternatively, the corresponding planar structures were obtained by optimizing the same initial structure with a $C_{i}$ symmetry constraint. The calculated energies were 
compared after the vibrational zero-point-energy correction. The nonplanar and planar structures optimized at the BHandHLYP/6-31G(d) level of theory are shown in Figure S37 as examples. Atomic coordinates for all the calculated structures are listed in Table S2-S9.

Table S1. Calculated energies ${ }^{a}$ for the planar and nonplanar conformers of tetraol $1 \mathbf{a}$.

\begin{tabular}{ccc|c} 
Method & $\begin{array}{c}\text { Planar } \\
{[\text { hartree }]}\end{array}$ & $\begin{array}{c}\text { Nonplanar } \\
{[\text { hartree }]}\end{array}$ & $\begin{array}{c}\text { Difference } \\
{[\text { hartree }]([\mathrm{kcal} / \mathrm{mol}])}\end{array}$ \\
\hline \hline HF/6-31G(d) & -1368.142775 & -1368.149013 & $0.006238(3.91)$ \\
B3LYP/6-31G(d) & -1376.600422 & -1376.605964 & $0.005542(3.47)$ \\
BHandHLYP/6-31G(d) & -1375.751465 & -1375.757104 & $0.005639(3.53)$ \\
M06-2X/6-31G(d) & -1376.023574 & -1376.029913 & $0.006339(3.97)$
\end{tabular}

${ }^{a}$ After the zero-point-energy correction.

(a)

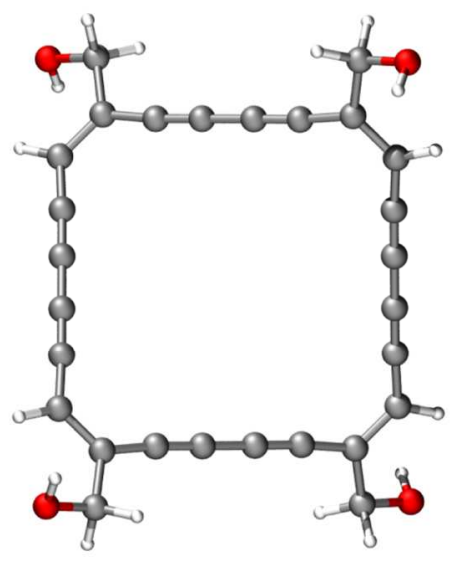

(c)

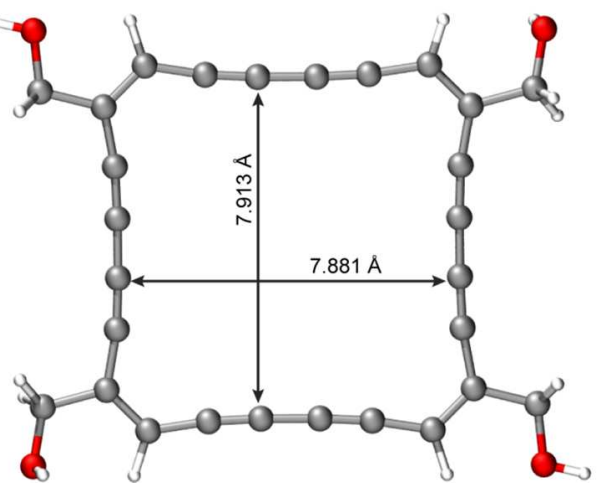

(b)

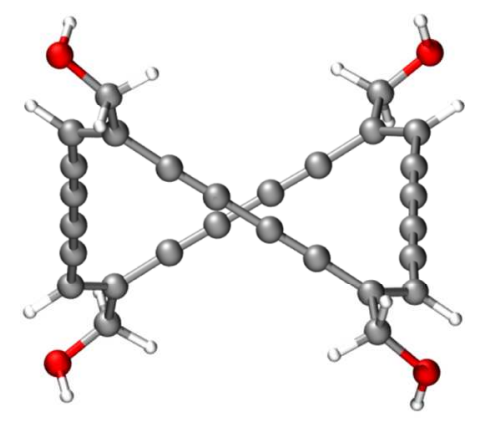

(d)

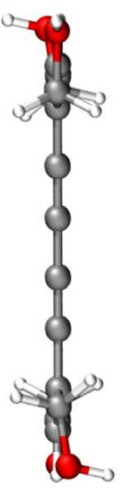

Figure S51. Optimized structures of 1 a at the BHandHLYP/6-31G(d) level of theory. (a,b) Nonplanar conformation. (c,d) Planar condormation. 
Table S2. Cartesian coordinates of the planar conformer of $\mathbf{1 a}$ optimized at the HF/6-31G(d) level of theory with a $C_{i}$ symmetry constraint.

\begin{tabular}{|c|c|c|c|}
\hline Symbol & $X$ & $\mathrm{Y}$ & Z \\
\hline $\mathrm{O}$ & -6.22203 & 0.120305 & 4.678751 \\
\hline $\mathrm{H}$ & -6.07613 & 1.024894 & 4.921057 \\
\hline $\mathrm{O}$ & 5.596551 & -0.04763 & 5.357223 \\
\hline $\mathrm{H}$ & 6.505858 & -0.04139 & 5.620379 \\
\hline $\mathrm{C}$ & -3.89123 & 0.001949 & -0.91485 \\
\hline $\mathrm{C}$ & -3.96274 & -0.01579 & 0.466737 \\
\hline $\mathrm{C}$ & -4.0833 & -0.03112 & 1.653107 \\
\hline $\mathrm{C}$ & -4.40888 & -0.05059 & 3.05021 \\
\hline $\mathrm{C}$ & -3.51001 & -0.08222 & 4.03099 \\
\hline $\mathrm{H}$ & -3.86961 & -0.12205 & 5.042441 \\
\hline $\mathrm{C}$ & -2.0892 & -0.07708 & 3.884448 \\
\hline $\mathrm{C}$ & -0.89659 & -0.07216 & 3.886193 \\
\hline $\mathrm{C}$ & 0.484076 & -0.06536 & 3.96598 \\
\hline $\mathrm{C}$ & 1.669059 & -0.05969 & 4.100503 \\
\hline $\mathrm{C}$ & 3.063892 & -0.05409 & 4.409899 \\
\hline $\mathrm{H}$ & 3.309174 & -0.06665 & 5.454484 \\
\hline $\mathrm{C}$ & 4.062803 & -0.03477 & 3.531907 \\
\hline $\mathrm{C}$ & 3.88985 & -0.01729 & 2.107176 \\
\hline $\mathrm{C}$ & 5.512612 & -0.02947 & 3.9644 \\
\hline $\mathrm{H}$ & 6.004684 & -0.89646 & 3.529115 \\
\hline $\mathrm{H}$ & 5.991114 & 0.856411 & 3.552716 \\
\hline $\mathrm{C}$ & -5.9035 & -0.059 & 3.334091 \\
\hline $\mathrm{H}$ & -6.38111 & 0.692394 & 2.711154 \\
\hline $\mathrm{H}$ & -6.30979 & -1.01951 & 3.042945 \\
\hline $\mathrm{O}$ & 6.222033 & -0.12031 & -4.67875 \\
\hline $\mathrm{H}$ & 6.076128 & -1.02489 & -4.92106 \\
\hline $\mathrm{O}$ & -5.59655 & 0.047631 & -5.35722 \\
\hline $\mathrm{H}$ & -6.50586 & 0.041388 & -5.62038 \\
\hline $\mathrm{C}$ & 3.891227 & -0.00195 & 0.914852 \\
\hline $\mathrm{C}$ & 3.962738 & 0.015794 & -0.46674 \\
\hline $\mathrm{C}$ & 4.083296 & 0.031116 & -1.65311 \\
\hline $\mathrm{C}$ & 4.408879 & 0.050589 & -3.05021 \\
\hline $\mathrm{C}$ & 3.510008 & 0.082221 & -4.03099 \\
\hline $\mathrm{H}$ & 3.86961 & 0.122051 & -5.04244 \\
\hline $\mathrm{C}$ & 2.089204 & 0.077079 & -3.88445 \\
\hline $\mathrm{C}$ & 0.896592 & 0.07216 & -3.88619 \\
\hline $\mathrm{C}$ & -0.48408 & 0.065361 & -3.96598 \\
\hline $\mathrm{C}$ & -1.66906 & 0.059694 & -4.1005 \\
\hline $\mathrm{C}$ & -3.06389 & 0.054093 & -4.4099 \\
\hline
\end{tabular}




\begin{tabular}{cccc}
$\mathrm{H}$ & -3.30917 & 0.066652 & -5.45448 \\
$\mathrm{C}$ & -4.0628 & 0.034771 & -3.53191 \\
$\mathrm{C}$ & -3.88985 & 0.01729 & -2.10718 \\
$\mathrm{C}$ & -5.51261 & 0.029473 & -3.9644 \\
$\mathrm{H}$ & -6.00468 & 0.896462 & -3.52912 \\
$\mathrm{H}$ & -5.99111 & -0.85641 & -3.55272 \\
$\mathrm{C}$ & 5.903495 & 0.058996 & -3.33409 \\
$\mathrm{H}$ & 6.381106 & -0.69239 & -2.71115 \\
$\mathrm{H}$ & 6.309789 & 1.019507 & -3.04295 \\
$\mathrm{C}$ & -3.37172 & -0.64864 & -6.44647 \\
$\mathrm{H}$ & -3.01506 & -1.65745 & -6.44647 \\
$\mathrm{H}$ & -3.01504 & -0.14424 & -5.57282 \\
$\mathrm{H}$ & -3.01504 & -0.14424 & -7.32012 \\
$\mathrm{H}$ & -4.44172 & -0.64863 & -6.44647 \\
\hline
\end{tabular}

Table S3. Cartesian coordinates of the nonplanar conformer of 1 a calculated at the HF/6-31G(d) level of theory.

\begin{tabular}{cccc}
\hline Symbol & $\mathrm{X}$ & $\mathrm{Y}$ & $\mathrm{Z}$ \\
\hline $\mathrm{O}$ & -5.03836 & -3.72161 & 3.618229 \\
$\mathrm{H}$ & -4.42997 & -4.41963 & 3.416067 \\
$\mathrm{O}$ & 4.692405 & 3.600093 & 4.150122 \\
$\mathrm{H}$ & 4.106082 & 4.301614 & 3.900438 \\
$\mathrm{C}$ & -3.58642 & 0.352961 & -0.75747 \\
$\mathrm{C}$ & -3.64155 & -0.4218 & 0.387508 \\
$\mathrm{C}$ & -3.68355 & -1.08475 & 1.377402 \\
$\mathrm{C}$ & -3.80478 & -1.91303 & 2.543422 \\
$\mathrm{C}$ & -2.91328 & -1.89925 & 3.532926 \\
$\mathrm{H}$ & -3.08312 & -2.52737 & 4.387277 \\
$\mathrm{C}$ & -1.73267 & -1.09424 & 3.556257 \\
$\mathrm{C}$ & -0.73794 & -0.43925 & 3.61189 \\
$\mathrm{C}$ & 0.415544 & 0.321464 & 3.674112 \\
$\mathrm{C}$ & 1.410461 & 0.976486 & 3.725787 \\
$\mathrm{C}$ & 2.587116 & 1.780871 & 3.830036 \\
$\mathrm{H}$ & 2.672426 & 2.395605 & 4.706463 \\
$\mathrm{C}$ & 3.570786 & 1.809253 & 2.932441 \\
$\mathrm{C}$ & 3.564374 & 0.999154 & 1.747512 \\
$\mathrm{C}$ & 4.799223 & 2.686906 & 3.102987 \\
$\mathrm{H}$ & 5.652482 & 2.057633 & 3.323365 \\
$\mathrm{H}$ & 5.006086 & 3.186859 & 2.160583 \\
$\mathrm{C}$ & -5.04333 & -2.79229 & 2.579889 \\
$\mathrm{H}$ & -5.91447 & -2.16585 & 2.725761 \\
& & &
\end{tabular}




\begin{tabular}{cccc}
$\mathrm{H}$ & -5.157 & -3.27748 & 1.614209 \\
$\mathrm{O}$ & 5.082882 & -3.65128 & -3.68951 \\
$\mathrm{H}$ & 4.47647 & -4.35404 & -3.49809 \\
$\mathrm{O}$ & -4.66854 & 3.650197 & -4.10928 \\
$\mathrm{H}$ & -4.0842 & 4.34946 & -3.84886 \\
$\mathrm{C}$ & 3.619531 & 0.351597 & 0.748122 \\
$\mathrm{C}$ & 3.676821 & -0.40536 & -0.4086 \\
$\mathrm{C}$ & 3.720672 & -1.05293 & -1.40855 \\
$\mathrm{C}$ & 3.844218 & -1.86289 & -2.58713 \\
$\mathrm{C}$ & 2.952656 & -1.83646 & -3.57632 \\
$\mathrm{H}$ & 3.124253 & -2.45092 & -4.4402 \\
$\mathrm{C}$ & 1.76978 & -1.03452 & -3.58733 \\
$\mathrm{C}$ & 0.773208 & -0.38157 & -3.63294 \\
$\mathrm{C}$ & -0.38243 & 0.37675 & -3.68351 \\
$\mathrm{C}$ & -1.37919 & 1.029674 & -3.72516 \\
$\mathrm{C}$ & -2.55812 & 1.832235 & -3.81709 \\
$\mathrm{H}$ & -2.64518 & 2.460093 & -4.68399 \\
$\mathrm{C}$ & -3.54184 & 1.844072 & -2.91918 \\
$\mathrm{C}$ & -3.53312 & 1.01592 & -1.74681 \\
$\mathrm{C}$ & -4.77276 & 2.720763 & -3.07628 \\
$\mathrm{H}$ & -4.98101 & 3.20562 & -2.12632 \\
$\mathrm{H}$ & -5.62424 & 2.092535 & -3.3063 \\
$\mathrm{C}$ & 5.085243 & -2.73798 & -2.63704 \\
$\mathrm{H}$ & 5.200307 & -3.2376 & -2.77327 \\
$\mathrm{H}$ & 5.954614 & -2.10692 & \\
\hline & & & \\
\hline
\end{tabular}

Table S4. Cartesian coordinates of the planar conformer of 1a calculated at the B3LYP/6-31G(d) level of theory with a $C_{i}$ symmetry constraint.

\begin{tabular}{cccc}
\hline Symbol & $\mathrm{X}$ & $\mathrm{Y}$ & $\mathrm{Z}$ \\
\hline $\mathrm{O}$ & -6.22152 & 0.157839 & 4.713908 \\
$\mathrm{H}$ & -5.9883 & 1.077287 & 4.920238 \\
$\mathrm{O}$ & 5.586205 & -0.051 & 5.408811 \\
$\mathrm{H}$ & 6.518767 & -0.04017 & 5.669004 \\
$\mathrm{C}$ & -3.94125 & -0.00373 & -0.91064 \\
$\mathrm{C}$ & -4.00827 & -0.02318 & 0.442432 \\
$\mathrm{C}$ & -4.09673 & -0.04208 & 1.664198 \\
$\mathrm{C}$ & -4.41657 & -0.06095 & 3.036718 \\
$\mathrm{C}$ & -3.50568 & -0.09332 & 4.05138 \\
$\mathrm{H}$ & -3.91077 & -0.134 & 5.061698 \\
$\mathrm{C}$ & -2.10826 & -0.08868 & 3.932624 \\
$\mathrm{C}$ & -0.88315 & -0.08135 & 3.956657
\end{tabular}




\begin{tabular}{|c|c|c|c|}
\hline $\mathrm{C}$ & 0.468121 & -0.07335 & 4.037231 \\
\hline $\mathrm{C}$ & 1.687887 & -0.06592 & 4.153416 \\
\hline $\mathrm{C}$ & 3.061154 & -0.05864 & 4.441349 \\
\hline $\mathrm{H}$ & 3.342087 & -0.07346 & 5.491852 \\
\hline $\mathrm{C}$ & 4.079363 & -0.0347 & 3.535128 \\
\hline $\mathrm{C}$ & 3.908291 & -0.01474 & 2.13475 \\
\hline $\mathrm{C}$ & 5.527444 & -0.0279 & 3.994695 \\
\hline $\mathrm{H}$ & 6.036146 & -0.90086 & 3.553504 \\
\hline $\mathrm{H}$ & 6.018196 & 0.869437 & 3.583139 \\
\hline $\mathrm{C}$ & -5.91497 & -0.06708 & 3.351926 \\
\hline $\mathrm{H}$ & -6.41702 & 0.658988 & 2.69483 \\
\hline $\mathrm{H}$ & -6.3287 & -1.05286 & 3.109529 \\
\hline $\mathrm{O}$ & 6.221523 & -0.15784 & -4.71391 \\
\hline $\mathrm{H}$ & 5.988298 & -1.07729 & -4.92024 \\
\hline $\mathrm{O}$ & -5.58621 & 0.050996 & -5.40881 \\
\hline $\mathrm{H}$ & -6.51877 & 0.040165 & -5.669 \\
\hline $\mathrm{C}$ & 3.941253 & 0.003728 & 0.910636 \\
\hline $\mathrm{C}$ & 4.008268 & 0.023178 & -0.44243 \\
\hline $\mathrm{C}$ & 4.096727 & 0.042079 & -1.6642 \\
\hline $\mathrm{C}$ & 4.416565 & 0.060948 & -3.03672 \\
\hline $\mathrm{C}$ & 3.50568 & 0.093324 & -4.05138 \\
\hline $\mathrm{H}$ & 3.91077 & 0.133997 & -5.0617 \\
\hline $\mathrm{C}$ & 2.108264 & 0.088677 & -3.93262 \\
\hline $\mathrm{C}$ & 0.883146 & 0.081349 & -3.95666 \\
\hline $\mathrm{C}$ & -0.46812 & 0.073347 & -4.03723 \\
\hline $\mathrm{C}$ & -1.68789 & 0.065919 & -4.15342 \\
\hline $\mathrm{C}$ & -3.06115 & 0.058641 & -4.44135 \\
\hline $\mathrm{H}$ & -3.34209 & 0.073456 & -5.49185 \\
\hline $\mathrm{C}$ & -4.07936 & 0.034699 & -3.53513 \\
\hline $\mathrm{C}$ & -3.90829 & 0.01474 & -2.13475 \\
\hline $\mathrm{C}$ & -5.52744 & 0.027899 & -3.9947 \\
\hline $\mathrm{H}$ & -6.03615 & 0.900857 & -3.5535 \\
\hline $\mathrm{H}$ & -6.0182 & -0.86944 & -3.58314 \\
\hline $\mathrm{C}$ & 5.914971 & 0.067081 & -3.35193 \\
\hline $\mathrm{H}$ & 6.417018 & -0.65899 & -2.69483 \\
\hline $\mathrm{H}$ & 6.328695 & 1.05286 & -3.10953 \\
\hline
\end{tabular}

Table S5. Cartesian coordinates of the nonplanar conformer of 1a calculated at the B3LYP/6-31G(d) level of theory.

\begin{tabular}{cccc}
\hline Symbol & $\mathrm{X}$ & $\mathrm{Y}$ & $\mathrm{Z}$ \\
\hline $\mathrm{O}$ & -5.36722 & -3.22272 & 3.97554
\end{tabular}




\begin{tabular}{|c|c|c|c|}
\hline $\mathrm{H}$ & -4.7486 & -3.95351 & 3.815579 \\
\hline $\mathrm{O}$ & 4.994894 & 3.094102 & 4.527529 \\
\hline $\mathrm{H}$ & 4.400512 & 3.831591 & 4.315115 \\
\hline $\mathrm{C}$ & -3.71339 & 0.278756 & -0.79332 \\
\hline $\mathrm{C}$ & -3.77161 & -0.35353 & 0.403555 \\
\hline $\mathrm{C}$ & -3.81777 & -0.91338 & 1.491829 \\
\hline $\mathrm{C}$ & -4.00069 & -1.60158 & 2.708746 \\
\hline $\mathrm{C}$ & -3.09604 & -1.58694 & 3.729961 \\
\hline $\mathrm{H}$ & -3.36846 & -2.12776 & 4.634984 \\
\hline $\mathrm{C}$ & -1.86058 & -0.92209 & 3.720355 \\
\hline $\mathrm{C}$ & -0.77183 & -0.36278 & 3.771534 \\
\hline $\mathrm{C}$ & 0.430201 & 0.256526 & 3.836213 \\
\hline $\mathrm{C}$ & 1.519023 & 0.814128 & 3.902301 \\
\hline $\mathrm{C}$ & 2.749551 & 1.473506 & 4.042246 \\
\hline $\mathrm{H}$ & 2.933708 & 2.002752 & 4.975914 \\
\hline $\mathrm{C}$ & 3.750244 & 1.494857 & 3.115099 \\
\hline $\mathrm{C}$ & 3.685267 & 0.822343 & 1.877563 \\
\hline $\mathrm{C}$ & 5.051468 & 2.248175 & 3.396082 \\
\hline $\mathrm{H}$ & 5.848766 & 1.524186 & 3.600918 \\
\hline $\mathrm{H}$ & 5.346271 & 2.797131 & 2.489003 \\
\hline $\mathrm{C}$ & -5.31827 & -2.36488 & 2.852592 \\
\hline $\mathrm{H}$ & -6.1367 & -1.64776 & 2.985488 \\
\hline $\mathrm{H}$ & -5.51885 & -2.90573 & 1.915401 \\
\hline $\mathrm{O}$ & 5.409768 & -3.14838 & -4.03706 \\
\hline $\mathrm{H}$ & 4.792793 & -3.88266 & -3.88714 \\
\hline $\mathrm{O}$ & -4.96907 & 3.149321 & -4.49457 \\
\hline $\mathrm{H}$ & -4.37678 & 3.885097 & -4.27067 \\
\hline $\mathrm{C}$ & 3.746638 & 0.278071 & 0.782155 \\
\hline $\mathrm{C}$ & 3.806501 & -0.33571 & -0.42423 \\
\hline $\mathrm{C}$ & 3.854107 & -0.87895 & -1.52083 \\
\hline $\mathrm{C}$ & 4.039007 & -1.54874 & -2.74767 \\
\hline $\mathrm{C}$ & 3.134346 & -1.52188 & -3.76863 \\
\hline $\mathrm{H}$ & 3.408275 & -2.04887 & -4.68132 \\
\hline $\mathrm{C}$ & 1.897075 & -0.86062 & -3.74937 \\
\hline $\mathrm{C}$ & 0.806835 & -0.30351 & -3.79209 \\
\hline $\mathrm{C}$ & -0.39684 & 0.313512 & -3.84731 \\
\hline $\mathrm{C}$ & -1.48715 & 0.869171 & -3.90477 \\
\hline $\mathrm{C}$ & -2.71944 & 1.527363 & -4.03443 \\
\hline $\mathrm{H}$ & -2.9051 & 2.070625 & -4.95968 \\
\hline $\mathrm{C}$ & -3.72015 & 1.531595 & -3.10709 \\
\hline $\mathrm{C}$ & -3.65339 & 0.8401 & -1.88015 \\
\hline $\mathrm{C}$ & -5.02337 & 2.285742 & -3.37641 \\
\hline $\mathrm{H}$ & -5.31966 & 2.81973 & -2.46092 \\
\hline
\end{tabular}




\begin{tabular}{llll}
$\mathrm{H}$ & -5.81873 & 1.562901 & -3.59252 \\
$\mathrm{C}$ & 5.358753 & -2.30619 & -2.90241 \\
$\mathrm{H}$ & 5.561168 & -2.85932 & -1.97281 \\
$\mathrm{H}$ & 6.175095 & -1.58496 & -3.02565 \\
\hline
\end{tabular}

Table S6. Cartesian coordinates of the planar conformer of 1 a calculated at the BHandHLYP/6-31G(d) level of theory with a $C_{i}$ symmetry constraint.

\begin{tabular}{|c|c|c|c|}
\hline Symbol & $X$ & $\mathrm{Y}$ & Z \\
\hline $\mathrm{O}$ & -6.18907 & 0.134203 & 4.681808 \\
\hline $\mathrm{H}$ & -5.98839 & 1.042629 & 4.911121 \\
\hline $\mathrm{O}$ & 5.558392 & -0.04766 & 5.364599 \\
\hline $\mathrm{H}$ & 6.47674 & -0.03984 & 5.630892 \\
\hline $\mathrm{C}$ & -3.8992 & -0.00036 & -0.90804 \\
\hline $\mathrm{C}$ & -3.96826 & -0.01876 & 0.452088 \\
\hline $\mathrm{C}$ & -4.07275 & -0.03605 & 1.654427 \\
\hline $\mathrm{C}$ & -4.39493 & -0.05532 & 3.031094 \\
\hline $\mathrm{C}$ & -3.4946 & -0.08744 & 4.027773 \\
\hline $\mathrm{H}$ & -3.88094 & -0.12855 & 5.034671 \\
\hline $\mathrm{C}$ & -2.09324 & -0.08256 & 3.897009 \\
\hline $\mathrm{C}$ & -0.88611 & -0.07615 & 3.910462 \\
\hline $\mathrm{C}$ & 0.472622 & -0.06858 & 3.990221 \\
\hline $\mathrm{C}$ & 1.673376 & -0.06188 & 4.11456 \\
\hline $\mathrm{C}$ & 3.049852 & -0.05532 & 4.41042 \\
\hline $\mathrm{H}$ & 3.317948 & -0.06845 & 5.454407 \\
\hline $\mathrm{C}$ & 4.053857 & -0.03418 & 3.518918 \\
\hline $\mathrm{C}$ & 3.881919 & -0.01607 & 2.11454 \\
\hline $\mathrm{C}$ & 5.493868 & -0.02814 & 3.966128 \\
\hline $\mathrm{H}$ & 5.993924 & -0.89605 & 3.53025 \\
\hline $\mathrm{H}$ & 5.978554 & 0.860509 & 3.555447 \\
\hline $\mathrm{C}$ & -5.88244 & -0.06124 & 3.33158 \\
\hline $\mathrm{H}$ & -6.37144 & 0.67855 & 2.696302 \\
\hline $\mathrm{H}$ & -6.2944 & -1.02998 & 3.060986 \\
\hline $\mathrm{O}$ & 6.189073 & -0.1342 & -4.68181 \\
\hline $\mathrm{H}$ & 5.98839 & -1.04263 & -4.91112 \\
\hline $\mathrm{O}$ & -5.55839 & 0.047659 & -5.3646 \\
\hline $\mathrm{H}$ & -6.47674 & 0.03984 & -5.63089 \\
\hline $\mathrm{C}$ & 3.899199 & 0.000358 & 0.908044 \\
\hline $\mathrm{C}$ & 3.968255 & 0.018758 & -0.45209 \\
\hline $\mathrm{C}$ & 4.072751 & 0.036051 & -1.65443 \\
\hline $\mathrm{C}$ & 4.394928 & 0.055315 & -3.03109 \\
\hline $\mathrm{C}$ & 3.494602 & 0.087436 & -4.02777 \\
\hline
\end{tabular}




\begin{tabular}{llll}
$\mathrm{H}$ & 3.880935 & 0.128551 & -5.03467 \\
$\mathrm{C}$ & 2.093239 & 0.082562 & -3.89701 \\
$\mathrm{C}$ & 0.886108 & 0.076145 & -3.91046 \\
$\mathrm{C}$ & -0.47262 & 0.068582 & -3.99022 \\
$\mathrm{C}$ & -1.67338 & 0.061877 & -4.11456 \\
$\mathrm{C}$ & -3.04985 & 0.055316 & -4.41042 \\
$\mathrm{H}$ & -3.31795 & 0.068451 & -5.45441 \\
$\mathrm{C}$ & -4.05386 & 0.034176 & -3.51892 \\
$\mathrm{C}$ & -3.88192 & 0.016066 & -2.11454 \\
$\mathrm{C}$ & -5.49387 & 0.028135 & -3.96613 \\
$\mathrm{H}$ & -5.99392 & 0.896045 & -3.53025 \\
$\mathrm{H}$ & -5.97855 & -0.86051 & -3.55545 \\
$\mathrm{C}$ & 5.882436 & 0.061238 & -3.33158 \\
$\mathrm{H}$ & 6.371437 & -0.67855 & -2.6963 \\
$\mathrm{H}$ & 6.294395 & 1.029982 & -3.06099 \\
\hline
\end{tabular}

Table S7. Cartesian coordinates of the nonplanar conformer of 1a calculated at the BHandHLYP/6$31 \mathrm{G}(\mathrm{d})$ level of theory.

\begin{tabular}{cccc}
\hline Symbol & $\mathrm{X}$ & $\mathrm{Y}$ & $\mathrm{Z}$ \\
\hline $\mathrm{O}$ & -5.14079 & -3.52054 & 3.758853 \\
$\mathrm{H}$ & -4.51064 & -4.21946 & 3.578626 \\
$\mathrm{O}$ & 4.782421 & 3.398702 & 4.292152 \\
$\mathrm{H}$ & 4.173937 & 4.100978 & 4.058504 \\
$\mathrm{C}$ & -3.62164 & 0.320864 & -0.76763 \\
$\mathrm{C}$ & -3.67805 & -0.39411 & 0.390556 \\
$\mathrm{C}$ & -3.72303 & -1.01918 & 1.421446 \\
$\mathrm{C}$ & -3.86981 & -1.78846 & 2.599775 \\
$\mathrm{C}$ & -2.97534 & -1.77535 & 3.60315 \\
$\mathrm{H}$ & -3.19337 & -2.37274 & 4.474672 \\
$\mathrm{C}$ & -1.78091 & -1.02919 & 3.613719 \\
$\mathrm{C}$ & -0.7478 & -0.40775 & 3.666939 \\
$\mathrm{C}$ & 0.416809 & 0.294577 & 3.729816 \\
$\mathrm{C}$ & 1.450014 & 0.915387 & 3.788208 \\
$\mathrm{C}$ & 2.640335 & 1.659065 & 3.905009 \\
$\mathrm{H}$ & 2.772724 & 2.24462 & 4.8014 \\
$\mathrm{C}$ & 3.628652 & 1.68295 & 2.994153 \\
$\mathrm{C}$ & 3.597247 & 0.929708 & 1.796898 \\
$\mathrm{C}$ & 4.876588 & 2.514834 & 3.212731 \\
$\mathrm{H}$ & 5.710759 & 1.852683 & 3.430137 \\
$\mathrm{H}$ & 5.120235 & 3.034896 & 2.285228 \\
$\mathrm{C}$ & -5.13072 & -2.62493 & 2.685006
\end{tabular}




\begin{tabular}{|c|c|c|c|}
\hline $\mathrm{H}$ & -5.98424 & -1.96682 & 2.826275 \\
\hline $\mathrm{H}$ & -5.28021 & -3.13512 & 1.732402 \\
\hline $\mathrm{O}$ & 5.185265 & -3.44749 & -3.8266 \\
\hline $\mathrm{H}$ & 4.557251 & -4.15104 & -3.65726 \\
\hline $\mathrm{O}$ & -4.75724 & 3.451506 & -4.25402 \\
\hline $\mathrm{H}$ & -4.15034 & 4.15135 & -4.00921 \\
\hline $\mathrm{C}$ & 3.654384 & 0.319812 & 0.757553 \\
\hline $\mathrm{C}$ & 3.712733 & -0.37718 & -0.41145 \\
\hline $\mathrm{C}$ & 3.759473 & -0.98629 & -1.45177 \\
\hline $\mathrm{C}$ & 3.90866 & -1.73716 & -2.64161 \\
\hline $\mathrm{C}$ & 3.014276 & -1.71155 & -3.64482 \\
\hline $\mathrm{H}$ & 3.234222 & -2.295 & -4.52525 \\
\hline $\mathrm{C}$ & 1.817633 & -0.96888 & -3.6442 \\
\hline $\mathrm{C}$ & 0.782735 & -0.34968 & -3.68792 \\
\hline $\mathrm{C}$ & -0.38385 & 0.350249 & -3.73999 \\
\hline $\mathrm{C}$ & -1.41877 & 0.969041 & -3.78876 \\
\hline $\mathrm{C}$ & -2.61107 & 1.711265 & -3.894 \\
\hline $\mathrm{H}$ & -2.74507 & 2.310395 & -4.78112 \\
\hline $\mathrm{C}$ & -3.59945 & 1.718405 & -2.98293 \\
\hline $\mathrm{C}$ & -3.56611 & 0.946807 & -1.79748 \\
\hline $\mathrm{C}$ & -4.84946 & 2.550444 & -3.18872 \\
\hline $\mathrm{H}$ & -5.09467 & 3.055163 & -2.25319 \\
\hline $\mathrm{H}$ & -5.6819 & 1.889714 & -3.41683 \\
\hline $\mathrm{C}$ & 5.172135 & -2.56841 & -2.73921 \\
\hline $\mathrm{H}$ & 5.322892 & -3.09264 & -1.79446 \\
\hline $\mathrm{H}$ & 6.023683 & -1.90563 & -2.8701 \\
\hline
\end{tabular}

Table S8. Cartesian coordinates of the planar conformer of 1a calculated at the M06-2X/6-31G(d) level of theory with a $C_{i}$ symmetry constraint.

\begin{tabular}{cccc}
\hline Symbol & $\mathrm{X}$ & $\mathrm{Y}$ & $\mathrm{Z}$ \\
\hline $\mathrm{O}$ & -6.22464 & 0.12663 & 4.681694 \\
$\mathrm{H}$ & -5.989 & 1.032833 & 4.92881 \\
$\mathrm{O}$ & 5.584858 & -0.06047 & 5.370936 \\
$\mathrm{H}$ & 6.514124 & -0.01493 & 5.629982 \\
$\mathrm{C}$ & -3.88986 & 0.009515 & -0.9125 \\
$\mathrm{C}$ & -3.95969 & -0.00795 & 0.455385 \\
$\mathrm{C}$ & -4.06626 & -0.02662 & 1.666975 \\
$\mathrm{C}$ & -4.40928 & -0.04965 & 3.044679 \\
$\mathrm{C}$ & -3.51777 & -0.09165 & 4.058195 \\
$\mathrm{H}$ & -3.91715 & -0.14081 & 5.068946 \\
$\mathrm{C}$ & -2.11011 & -0.09085 & 3.929576
\end{tabular}




\begin{tabular}{|c|c|c|c|}
\hline $\mathrm{C}$ & -0.89373 & -0.08589 & 3.94123 \\
\hline $\mathrm{C}$ & 0.472841 & -0.07904 & 4.02154 \\
\hline $\mathrm{C}$ & 1.682585 & -0.07164 & 4.148985 \\
\hline $\mathrm{C}$ & 3.065353 & -0.06128 & 4.444915 \\
\hline $\mathrm{H}$ & 3.345527 & -0.07133 & 5.494648 \\
\hline $\mathrm{C}$ & 4.063252 & -0.03842 & 3.53621 \\
\hline $\mathrm{C}$ & 3.872282 & -0.02397 & 2.128371 \\
\hline $\mathrm{C}$ & 5.513146 & -0.02233 & 3.966838 \\
\hline $\mathrm{H}$ & 6.018169 & -0.88552 & 3.507411 \\
\hline $\mathrm{H}$ & 5.981386 & 0.885703 & 3.557359 \\
\hline $\mathrm{C}$ & -5.90573 & -0.04686 & 3.325006 \\
\hline $\mathrm{H}$ & -6.37933 & 0.714879 & 2.689488 \\
\hline $\mathrm{H}$ & -6.32301 & -1.01492 & 3.028687 \\
\hline $\mathrm{O}$ & 6.224642 & -0.12663 & -4.68169 \\
\hline $\mathrm{H}$ & 5.988997 & -1.03283 & -4.92881 \\
\hline $\mathrm{O}$ & -5.58486 & 0.060474 & -5.37094 \\
\hline $\mathrm{H}$ & -6.51412 & 0.014925 & -5.62998 \\
\hline $\mathrm{C}$ & 3.889859 & -0.00952 & 0.912496 \\
\hline $\mathrm{C}$ & 3.95969 & 0.007947 & -0.45539 \\
\hline $\mathrm{C}$ & 4.066255 & 0.026624 & -1.66698 \\
\hline $\mathrm{C}$ & 4.409281 & 0.049649 & -3.04468 \\
\hline $\mathrm{C}$ & 3.517767 & 0.091645 & -4.0582 \\
\hline $\mathrm{H}$ & 3.917153 & 0.140809 & -5.06895 \\
\hline $\mathrm{C}$ & 2.110107 & 0.090846 & -3.92958 \\
\hline $\mathrm{C}$ & 0.893732 & 0.085892 & -3.94123 \\
\hline $\mathrm{C}$ & -0.47284 & 0.079036 & -4.02154 \\
\hline $\mathrm{C}$ & -1.68259 & 0.07164 & -4.14899 \\
\hline $\mathrm{C}$ & -3.06535 & 0.061278 & -4.44492 \\
\hline $\mathrm{H}$ & -3.34553 & 0.071333 & -5.49465 \\
\hline $\mathrm{C}$ & -4.06325 & 0.038416 & -3.53621 \\
\hline $\mathrm{C}$ & -3.87228 & 0.023969 & -2.12837 \\
\hline $\mathrm{C}$ & -5.51315 & 0.022325 & -3.96684 \\
\hline $\mathrm{H}$ & -6.01817 & 0.885515 & -3.50741 \\
\hline $\mathrm{H}$ & -5.98139 & -0.8857 & -3.55736 \\
\hline $\mathrm{C}$ & 5.905732 & 0.046861 & -3.32501 \\
\hline
\end{tabular}

Table S9. Cartesian coordinates of the nonplanar conformer of 1 a calculated at the M06-2X/6-31G(d) level of theory.

\begin{tabular}{cccc}
\hline Symbol & $\mathrm{X}$ & $\mathrm{Y}$ & $\mathrm{Z}$ \\
\hline $\mathrm{O}$ & -4.99347 & -3.7911 & 3.594032 \\
$\mathrm{H}$ & -4.30721 & -4.43874 & 3.376961
\end{tabular}




\begin{tabular}{|c|c|c|c|}
\hline $\mathrm{O}$ & 4.597227 & 3.693515 & 4.094308 \\
\hline $\mathrm{H}$ & 3.91207 & 4.324002 & 3.828476 \\
\hline $\mathrm{C}$ & -3.55298 & 0.354901 & -0.73557 \\
\hline $\mathrm{C}$ & -3.61178 & -0.42436 & 0.389526 \\
\hline $\mathrm{C}$ & -3.65382 & -1.10855 & 1.39372 \\
\hline $\mathrm{C}$ & -3.78776 & -1.94753 & 2.532256 \\
\hline $\mathrm{C}$ & -2.8939 & -1.95372 & 3.546202 \\
\hline $\mathrm{H}$ & -3.09162 & -2.60495 & 4.394331 \\
\hline $\mathrm{C}$ & -1.72988 & -1.1504 & 3.580696 \\
\hline $\mathrm{C}$ & -0.72478 & -0.46777 & 3.633127 \\
\hline $\mathrm{C}$ & 0.403708 & 0.30526 & 3.692254 \\
\hline $\mathrm{C}$ & 1.405094 & 0.993458 & 3.743317 \\
\hline $\mathrm{C}$ & 2.555581 & 1.812099 & 3.82908 \\
\hline $\mathrm{H}$ & 2.66312 & 2.450176 & 4.702999 \\
\hline $\mathrm{C}$ & 3.537165 & 1.841936 & 2.900322 \\
\hline $\mathrm{C}$ & 3.523771 & 1.022182 & 1.74 \\
\hline $\mathrm{C}$ & 4.742026 & 2.755573 & 3.058591 \\
\hline $\mathrm{H}$ & 5.618831 & 2.149602 & 3.308587 \\
\hline $\mathrm{H}$ & 4.948277 & 3.236353 & 2.091859 \\
\hline $\mathrm{C}$ & -5.02169 & -2.83495 & 2.565265 \\
\hline $\mathrm{H}$ & -5.90333 & -2.21089 & 2.745285 \\
\hline $\mathrm{H}$ & -5.15122 & -3.29624 & 1.576163 \\
\hline $\mathrm{O}$ & 5.037683 & -3.72198 & -3.66436 \\
\hline $\mathrm{H}$ & 4.353903 & -4.37496 & -3.45553 \\
\hline $\mathrm{O}$ & -4.57409 & 3.743168 & -4.05089 \\
\hline $\mathrm{H}$ & -3.88856 & 4.370266 & -3.77802 \\
\hline $\mathrm{C}$ & 3.586416 & 0.354928 & 0.725567 \\
\hline $\mathrm{C}$ & 3.646835 & -0.40657 & -0.41157 \\
\hline $\mathrm{C}$ & 3.690328 & -1.07522 & -1.4261 \\
\hline $\mathrm{C}$ & 3.8267 & -1.89672 & -2.57703 \\
\hline $\mathrm{C}$ & 2.93298 & -1.89098 & -3.59106 \\
\hline $\mathrm{H}$ & 3.133138 & -2.52916 & -4.44845 \\
\hline $\mathrm{C}$ & 1.76648 & -1.09082 & -3.61424 \\
\hline $\mathrm{C}$ & 0.75942 & -0.41038 & -3.65685 \\
\hline $\mathrm{C}$ & -0.37126 & 0.360246 & -3.70435 \\
\hline $\mathrm{C}$ & -1.37448 & 1.046476 & -3.74484 \\
\hline $\mathrm{C}$ & -2.52723 & 1.86334 & -3.81674 \\
\hline $\mathrm{H}$ & -2.63754 & 2.515233 & -4.68003 \\
\hline $\mathrm{C}$ & -3.5079 & 1.87602 & -2.88665 \\
\hline $\mathrm{C}$ & -3.4919 & 1.038118 & -1.73943 \\
\hline $\mathrm{C}$ & -4.71474 & 2.789799 & -3.02881 \\
\hline $\mathrm{H}$ & -4.91931 & 3.256032 & -2.05462 \\
\hline $\mathrm{H}$ & -5.59116 & 2.186089 & -3.28546 \\
\hline
\end{tabular}




\begin{tabular}{llll}
$\mathrm{C}$ & 5.063437 & -2.77973 & -2.6228 \\
$\mathrm{H}$ & 5.194992 & -3.25378 & -1.64 \\
$\mathrm{H}$ & 5.943007 & -2.15045 & -2.79484 \\
\hline
\end{tabular}




\section{Transfer integral analyses}

\subsection{Full citation for $A D F 2013$}

(1) te Velde, G.; Bickelhaupt, F. M.; van Gisbergen, S. J. A.; Fonseca Guerra, C.; Baerends, E. J.; Snijders, J. G.; Ziegler, T.; Chemistry with ADF, J. Comput. Chem. 2001, 22, 931.

(2) Fonseca Guerra, C; Snijders, J. G.; te Velde, G.; Baerends, E. J. Towards an order-N DFT method, Theor. Chem. Acc. 1998, 99, 391.

(3) ADF2013, SCM, Theoretical Chemistry, Vrije Universiteit, Amsterdam, The Netherlands, http://www.scm.com.

\subsection{Method and results}

All calculations were performed using the $A D F 2013$ program suite, and based on the crystal structures $^{\mathrm{S7}-\mathrm{S9}}$ without geometry optimization. The transfer integrals for the reference structures are summarized in Figure S52.

(a)

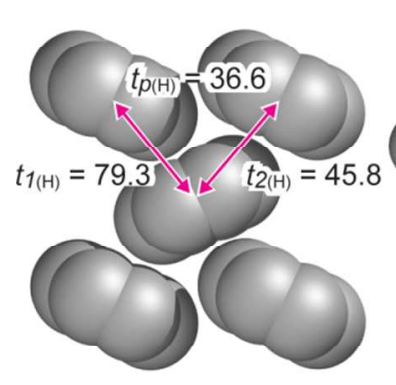

(b)

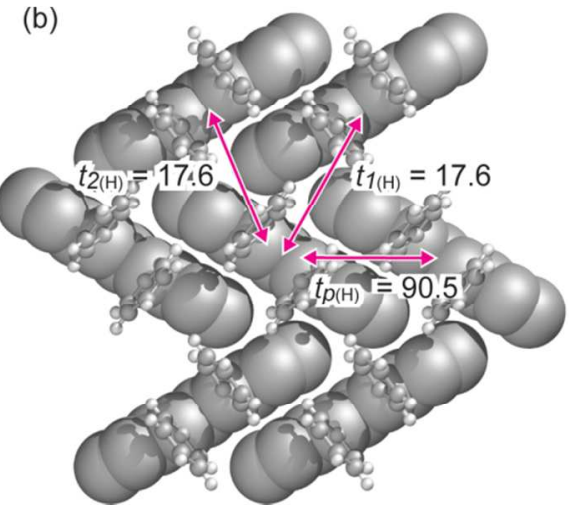

(c)

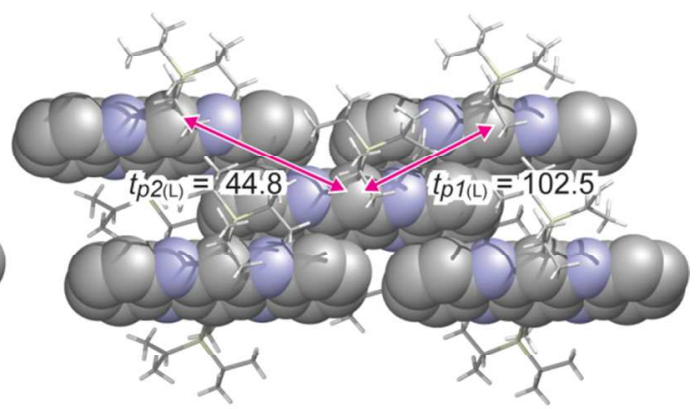

Figure S52. Transfer integrals calculated at the PW91/TZP level of theory for HOMOs of pentacene (a), ${ }^{\mathrm{S} 7}$ HOMOs of rubrene (b), ${ }^{\mathrm{S} 8}$ and LUMOs of bis(triisopropylsilylethynyl)tetraazapentacene. ${ }^{\mathrm{S} 9}$ The values are in the meV unit. 


\section{References}

S1. Schauer, C. L.; Matwey, E.; Fowler, F. W.; Lauher, J. W. J. Am. Chem. Soc. 1997, 119, 10245-10246.

S2. Suzuki, M.; Comito, A.; Khan, S. I.; Rubin, Y. Org. Lett. 2010, 12, 2346-2349.

S3. Tagliatesta, P.; Giovannetti, D.; Leoni, A.; Neves, M. G. P. M. S.; Cavaleiro, J. A. S. J. Mol. Catal. A: Chem. 2006, 252, 96-102.

S4. Kumar, G. D. K.; Chavarria, G. E.; Charlton-Sevcik, A. K.; Yoo, G. K.; Song, J.; Strecker, T. E.; Siim, B. G.; Chaplin, D. J.; Trawick, M. L.; Pinney, K. G. Bioorg. Chem. Med. Lett. 2010, 20, 66106615.

S5. Zubarev, E. R.; Stupp, S. I. J. Am. Chem. Soc. 2002, 124, 5762-5773.

S6. APEX2 v2.2-0 and SAINT v7.34A data collection and data processing programs, respectively. Bruker Analytical X-ray Instruments, Inc., Madison, WI; SADABS v2008/1 semi-empirical absorption correction program. G.M. Sheldrick, University of Göttingen, Germany.

S7. Mattheus, C. C.; Dros, A. B.; Baas, J.; Meetsma, A.; de Boer, J. L.; Palstra, T. T. M. Acta Crystallogr., Sect. C: Struct. Chem. 2001, 57, 939-941.

S8. Meetsma, A.; Jurchescu, O. D.; Palstra, T. M. Acta Crystallogr., Sect. B: Struct. Sci., Cryst. Eng. Mater. 2006, 62, 330-334.

S9. Liang, Z.; Tang, Q.; Xu, J.; Miao, Q. Adv. Mater. 2011, 23, 1535-1539. 